NBER WORKING PAPER SERIES

THE UNHOLY TRINITY:

REGULATORY FORBEARANCE, STRESSED BANKS AND ZOMBIE FIRMS

\author{
Anusha Chari \\ Lakshita Jain \\ Nirupama Kulkarni \\ Working Paper 28435 \\ http://www.nber.org/papers/w28435 \\ NATIONAL BUREAU OF ECONOMIC RESEARCH \\ 1050 Massachusetts Avenue \\ Cambridge, MA 02138 \\ February 2021
}

We thank workshop participants at Columbia University, UNC-Chapel Hill, the Reserve Bank of India, the IIM Calcutta-NYU Stern India Conference, Norges Bank, and the FDIC for helpful comments and suggestions. We thank Viral Acharya, Arvind Panagariya, Jagdish Bhagwati, Pravin Krishna, Suresh Sundaresan, Manju Puri, the late Subir Gokarn, Yasser Boualam, Rakesh Mohan, and Krishnamurthy Subrahmanian for helpful discussions. The views expressed herein are those of the authors and do not necessarily reflect the views of the National Bureau of Economic Research.

NBER working papers are circulated for discussion and comment purposes. They have not been peer-reviewed or been subject to the review by the NBER Board of Directors that accompanies official NBER publications.

(C) 2021 by Anusha Chari, Lakshita Jain, and Nirupama Kulkarni. All rights reserved. Short sections of text, not to exceed two paragraphs, may be quoted without explicit permission provided that full credit, including $\odot$ notice, is given to the source. 
The Unholy Trinity: Regulatory Forbearance, Stressed Banks and Zombie Firms Anusha Chari, Lakshita Jain, and Nirupama Kulkarni

NBER Working Paper No. 28435

February 2021

JEL No. E58,G21,G28

\section{ABSTRACT}

During the global financial crisis, the Reserve Bank of India enacted forbearance measures that lowered capital provisioning rates for loans under temporary liquidity stress. Matched bank-firm data reveal that troubled banks took advantage of the policy to also shield firms facing serious solvency issues. Perversely, in industries and bank portfolios with high proportions of failing firms, credit to healthy firms declined and was reallocated to the weakest firms. By incentivizing banks to hide true asset quality, the forbearance policy provided a license for regulatory arbitrage. The build-up of stressed assets in India's predominantly state-owned banking system is consistent with accounting subterfuge.

Anusha Chari

Department of Economics, CB \#3305

University of North Carolina at Chapel Hill

Chapel Hill, NC 27599

and NBER

achari@unc.edu

Lakshita Jain

University of North Carolina at Chapel Hill laksh21@email.unc.edu
Nirupama Kulkarni

Research Director

CAFRAL, Research Department

Reserve Bank of India Main Building,

Mezzanine Floor,

Shahid Bhagat Singh Road,

Fort, Mumbai 400001

nirupama.kulkarni@gmail.com 


\section{Introduction}

Regulatory forbearance can create dueling incentives $]^{1}$ On the one hand, forbearance provides a risk management tool for the temporarily problematic loans of viable firms. It allows otherwise solvent firms facing temporary liquidity shortages to remain in operation. On the other hand, forbearance can lead to a misallocation of credit enabling banks to keep non-performing assets on their balance sheets and zombie firms afloat (Caballero, Hoshi, and Kashyap, 2008, Peek and Rosengren, 2005, Acharya et al., 2019, Blattner, Farinha, and Rebelo, 2019). Forbearance as a means to shield non-performing assets can therfore reduce bank incentives to appropriately provision for and manage credit risk in loan portfolios.

This paper investigates the role of regulatory forbearance in propagating the misallocation of credit in India, the world's fifth-largest economy. The paper examines whether the forbearance measures enacted by the Reserve Bank of India (RBI) ${ }^{2}$ during the global financial crisis effectively handed over a license for banks to engage in regulatory arbitrage. We investigate whether the measures provided banks with an incentive to hide true asset quality, and therefore the build-up of stressed assets in the banking system is a by-product of accounting subterfuge. Using both bank and firm-level data, our primary goal is to examine the externalities and costs generated by asset quality forbearance.

To provide some context, the share of non-performing and restructured assets in India's banking system rose significantly between 2008 and 2018 3 Before the global financial crisis India had the lowest non-performing asset (NPA) ratios amongst G-20 nations-by 2018, it had the highest NPA ratio. India's NPA ratio is also higher than its emerging market counterparts. $4^{4}$ The data show falling profitability and capital provisioning ratios accompanied by a collapse in credit, especially for state-owned banks (Figure 1 and Figure IA.1). A

\footnotetext{
${ }^{1}$ Forbearance refers to the loan concessions or temporary repayment relief granted by creditors or lenders to alleviate short-term financial difficulties facing borrowers. The temporary difficulties typically arise from special economic or legal circumstances facing borrowers or adverse external shocks such as financial crises.

${ }^{2}$ The Reserve Bank of India functions as the central bank of India and also the regulator. In many other countries, separate agencies perform central banking and regulatory functions.

${ }^{3}$ https://www.epw.in/journal/2018/34/perspectives/non-performing-assets-commercial-banks.html

${ }^{4}$ https://timesofindia.indiatimes.com/business/india-business/only-4-major-nations-have-higher-badloans-than-india/articleshow/62275553.cms
} 
contemporaneous development is the declining credit quality of Indian firms - the aggregate interest coverage ratio declined significantly while leverage remained unchanged suggesting that the debt service capacity of the Indian corporate sector declined measurably over this period. 5

The rationale for the asset quality forbearance was to provide temporary relief for capital provisioning requirements associated with loans given to firms facing liquidity problems during the crisis. Specifically, subject to some conditions, the forbearance measures permitted loan accounts of firms to retain their 'standard' or good standing classification post restructuring due to missed payments (Master Circular - Prudential Norms on Income Recognition, Asset Classification and Provisioning Pertaining to Advances, 2009)..$^{6}$ In the absence of forbearance, these assets would be immediately classified as non-performing and subject to higher capital provisioning requirements.7 In this paper we investigate whether regulatory forbearance was used by banks to assist low-liquidity firms, the intended beneficiaries, or whether the policies also allowed banks to shield firms facing solvency issues, the unintended beneficiaries.

Along with rising shares of non-performing assets, we see zombie firms emerging on a large scale in the Indian corporate sector. Thus, the system suffers from a twin balance sheet problem where both the banking sector and the corporate sector are under financial stress. In Europe, Acharya et al. (2019) show that while zombie lending is initially successful at keeping troubled borrowers alive, many zombie firms likely fail when forbearance is ultimately withdrawn. In 2016, for approximately $40 \%$ of the our sample of non-financial firms the

\footnotetext{
${ }^{5}$ In a study, Ansari, Khandelwal, and Prabhala (2016) find that over the sample time period, the aggregate interest coverage ratio for the corporate sector as a whole changes from a peak of 6.92 in 2007 to nearly half at 3.38 by 2015 .

${ }^{6}$ See Part B in https://rbi.org.in/scripts/NotificationUser.aspx?Id=5090\&Mode $=0$

${ }^{7}$ Prior to 2008, commercial bank loan portfolios under the RBI's asset classification norms were broadly classified as "standard" (assets in good standing) or non-performing assets (NPAs). Additional subclassifications of NPAs depending on over-due principal and/or interest, further categorized bank assets as sub-standard, doubtful and loss assets. Standard advances restructured for delays or non-payment were immediately re-classified as sub-standard and NPAs re-classified to further lower categories such as from sub-standard to doubtful and so on.
} 
interest coverage ratio was less than two $8^{8}$ We hypothesize that the RBI's forbearance policy between 2008-2015 was associated with lending to zombie firms potentially crowding out more productive lending to healthy firms.

We begin by constructing a timeline of the RBI's forbearance stance by carefully parsing policy statements in a series of official circulars posted on the RBI website. $9^{9}$ Banking secrecy laws in India disallow banks from revealing information about their borrowers. ${ }^{10}$ Fortuitously, firms can voluntarily choose to disclose information about their lenders. We take advantage of this asymmetry in information revelation and use a forensic approach to compile a matched firm-bank dataset with corresponding firm and bank fundamentals. Using information about banks listed on firm financial statements in the CMIE's Prowess database we build a bridge that connects banks and firms and allows us to construct bank-lending portfolios.

Prowess provides detailed financial statements from a wide universe of public and private Indian firms that we use to construct firm-level measures such as liquidity, solvency, firm size and so on. We construct bank-level measures of distress from the Basic Statistical Returns of Scheduled Commercial Banks published annually on by the RBI ${ }^{11}$ In the matched dataset of firms and their lead banks, our sample has approximately 8,000 firms over the 2006-2016 period. We also use hand-collected information on restructured loans from the Ministry of Corporate Affairs in supplemental analysis. We use these data to examine the relationship between the timeline of the regulatory forbearance policy of the Reserve Bank of India, bank health status, and the liquidity/solvency status of borrower firms. ${ }^{12}$

Our main findings are as follows. First, we document a strong positive correlation be-

\footnotetext{
${ }^{8}$ Additionally, for $21 \%$ of the firms earnings were lower than interest payments with an interest coverage ratio less than one. The interest coverage ratio is defined as Earnings before Interest and Taxes $(\mathrm{EBIT}) /$ Interest Expense.

${ }^{9}$ The circulars are posted on https://rbi.org.in/Scripts/BS_CircularIndexDisplay.aspx dated August 2008 to February 2018, the relevant time-frame for the forbearance related measures in India.

${ }^{10}$ The Public Financial Institutions Obligation as to Fidelity and Secrecy) ACT, 1983. http://legislative.gov.in/sites/default/files/A1983-48.pdf

${ }^{11}$ Data are available on the RBI's online portal, Database on Indian Economy (DBIE)

${ }^{12}$ We classify banks into stressed and healthy banks based on the proportions of non-performing loans in the total gross advances lent out by the bank in 2007, i.e., before the introduction of forbearance policy by RBI.
} 
tween firm- and bank-distress over the period 2006-2016. Simple univariate regressions show a statistically significant correlation between the proportion of low-liquidity and low-solvency firms in bank portfolios and the proportion of distressed assets on individual bank balance sheets, suggesting a strong co-incidence between bank- and firm-distress. Second, using a triple interaction specification in a pooled regression setting, we show that indirect recapitalization schemes like forbearance in the classification of stressed loans may have encouraged banks to channel debt not only to firms with low-liquidity but also to low-solvency borrowers. Stressed banks also significantly increase lending to zombie borrowers. The pattern of lending appears inconsistent with the intent of the forbearance policy. It is also surprising that we do not find a change in lending patterns following forbearance withdrawal suggesting that prolonged periods of asset-quality forbearance may have persistent effects.

Note that the triple difference estimates are plausibly causal given that the implicit parallel trends assumption is not violated. While zombie and non-zombie firms may have been on different time-trends prior to the introduction of the forbearance schemes, the relative difference between zombie and non-zombie firms were on similar time-trends at stressed and non-stressed banks, which is the variation we exploit in the triple difference specification.

Third, we examine the match between zombie firms and stressed banks which may adversely affect the ability of healthy firms to borrow from these banks, especially if the stressed banks also dominate lending to particular industries. McGowan, Andrews, and Millot (2018) suggest that there may be a policy dimension, including bank forbearance policies, to the problem of zombie lending prevalent in many countries. We document a statistically significant increase in zombie lending by stressed banks during the forbearance period. ${ }^{13}$

Collectively, our findings suggest that the lending norms relaxed during the forbearance period promoted loans from stressed banks to their existing low-quality borrowers. These loans likely enabled zombie firms to continue servicing their old loans, i.e., forbearance facilitated the ever-greening of previous loans exacerbating the 'extend and pretend' phenomenon.

\footnotetext{
${ }^{13} \mathrm{~A}$ firm is classified as a zombie if the firm received subsidized credit, i.e., the firm is able to borrow loans at an average interest rate that is lower than the Prime Lending Rate (PLR) of State Bank of India and has a debt-to-assets ratio greater than 0.15 .
} 
Also, stressed bank lending to zombie firms remains relatively stable subsequent to forbearance withdrawal suggesting sticky matches between stressed banks and low-quality borrowers that strengthened during times of forbearance. While prior literature shows that insufficient recapitalization can perversely increase zombie lending (Acharya et al., 2019, Blattner, Farinha, and Rebelo, 2019), our results highlight that the perverse matching between the unhealthy banks and zombie firms may also render future recapitalization ineffective.

Our evidence is consistent with a misallocation of credit by marginal banks, i.e., banks close to their minimum capital requirement may avoid loan loss recognition either due to sunk costs or soft budget constraints (Peek and Rosengren, 2005, Dewatripont and Maskin, 1995) and face perverse incentives to provide additional credit to severely impaired borrowers 14 Marginal banks continue to evergreen loans, essentially gambling for resurrection (Freixas, Rochet, and Parigi, 2010, Acharya et al., 2011, Baldursson and Portes, 2013, Koudstaal and Van Wijnbergen, 2012) ${ }^{15}$ Ben-David, Palvia, and Stulz (2019) provide a nice survey of the broad literature on gambling for resurrection. Our paper shows that compared to their healthy counterparts, stressed banks had higher proportions of low-solvency and zombie firms in their loan portfolios and after the introduction of forbearance were more likely to increase lending to these firm-types. Using supplemental loan-level data on restructured loans, we exploit within-firm variation and show that stressed banks had higher loan restructuring rates compared with healthier banks. Thus, even accounting for demand-side factors we see a greater increase in zombie lending by stressed banks.

Spillover effects from zombie lending can crowd out healthy firms by reducing their access to bank credit (Caballero, Hoshi, and Kashyap, 2008). To test this congestion hypothesis in bank lending, we examine the spillovers to the leverage ratios of higher quality borrowers in industries that have high proportions of zombie firms and also on the lending patterns

\footnotetext{
${ }^{14}$ For example, with sunk costs and ex-ante asymmetric information, theoretically motivate how banks may continue lending to inefficient borrowers even after the borrower type is revealed. Peek and Rosengren (2005) suggest soft budget constraints as an explanation for lending inefficiencies in Japan.

${ }^{15}$ The papers cited here document evidence of gambling or risk-shifting by banks as a distress response in the aftermath of recent crises. However, there is also literature suggesting that regulatory and governance measures could serve to limit risk-taking behaviors (Laeven and Levine, 2009, Benston and Kaufman, 1997. Akhigbe and Whyte, 2001).
} 
of banks with high proportions of zombie firms in their portfolios. We find that in industries with high proportions of zombie firms lending to healthy firms declines significantly during the forbearance period. Similarly, lending to healthy firms declines significantly as the proportion of zombies in bank lending portfolios increase. Consistent with the literature documenting that zombie-lending can distort competition by subsidizing credit to inefficient firms (Storz et al., 2017, Andrews and Petroulakis, 2019, and McGowan, Andrews, and Millot, 2018), we find that zombie lending crowds out healthy firms via both industry and bank congestion channels. We also provide evidence that the healthier firms migrate away from government-owned banks to form new banking relationships with private sector banks, creating a separating equilibrium of sticky matches between stressed banks and weak firms that persists after forbearance withdrawal.

We follow Banerjee and Hofmann (2018) and Caballero, Hoshi, and Kashyap (2008) and examine the real effects of the forbearance policy by looking at real investment and employment. Capital expenditures by low-solvency firms borrowing from stressed banks decline significantly during the forbearance phase. However, the wage bill for these firms is positively and statistically significantly correlated with the implementation of forbearance suggesting that, in addition to repaying existing loans, low-quality borrowers may have used the new loans for wage payments. We do not discern a statistically significant pattern in the capital or wage expenditures for low-liquidity firms in the forbearance or withdrawal periods. The overall pattern of results suggests that forbearance may have had the unintended consequence of propping up low solvency firms and not temporarily liquidity constrained firms as originally intended.

We conclude with a discussion of several robustness checks and also provide evidence that forbearance implementation is consistent with implicit sovereign backing especially for state-owned banks. Our main set of results focus on lending to otherwise insolvent borrowers by stressed banks. We hypothesize that relaxing provisioning norms during the forbearance period may facilitate the ever-greening of loans to zombie firms. While the reduced provisioning requirements can allow banks to engage in regulatory arbitrage, they may also allow the 
sovereign to postpone recapitalization - particularly the state-owned banks of which they are the majority owner - kicking the can down the road. We show that indeed, the bulk of the zombie lending during the forbearance period was concentrated in the state-owned banks. The finding is consistent with the conjecture that the sovereign may favor budget-neutral forbearance schemes in lieu of costly bank recapitalization. Indeed Acharya (2020) argues that forbearance is a manifestation of fiscal dominance, deferring the risk-weights attached to problematic loans (Patel, 2020).

To address the endogeneity concern that greater forbearance is more likely for firms and by extension to banks that are expected to recover quickly, we turn to an alternative identification strategy using proximity to the regulator, the RBI. Consistent with Gropp et al. (2020), we use proximity to the regulator as a proxy for the influence that the banks can exert on the regulator. Further, since forbearance schemes are implicitly backed by the government, pressures to forbear may be further concentrated in state-owned banks. Using the proximity measure, we find that state-owned banks with greater forbearance increased debt to zombie firms by 25 percent during the forbearance period and there were no statistically discernible changes in the withdrawal phase. Further, we do not uncover similar patterns of zombie firms lending by private sector banks assuaging concerns that results are driven by proximity to Mumbai, the financial capital of India.

The paper proceeds as follows. Section 2 describes the related literature. Section 3 provides background details of the RBI's forbearance policy in the aftermath of the global financial crisis. Section 4 describes our data sources and presents summary statistics. Section 5 presents our findings on (i) the lending patterns to low-solvency and low-liquidity borrowers following the implementation and withdrawal of forbearance; (ii) lending to zombie firms; (iii) the spillovers to healthy firms, and (iv) the real effects of forbearance. Section 6 presents robustness checks and alternative tests. Section 7 provides a discussion of our results and concludes. 


\section{Related Literature}

Our paper makes contributions to several strands of the literature. Seminal papers in the literature on weakly capitalized banks, zombie firms and the misallocation of credit focused on Japanese banks (Caballero, Hoshi, and Kashyap, 2008, Peek and Rosengren, 2005). More recently, the emphasis has shifted to European banks (Acharya et al., 2019, Blattner, Farinha, and Rebelo, 2019, and Gopinath et al., 2017).

Our nearest neighbor in the literature is Acharya et al. (2019), which examines the impact of unconventional monetary policy on credit misallocation in Europe. New lending at advantageous conditions provided impaired borrowers with the liquidity necessary to meet payments on their outstanding loans and allowed banks to defer loan loss recognition. Our paper shows that asset quality forbearance allowed banks to not only lend to low-liquidity borrowers, but that the unintended beneficiaries of the policy were low-solvency or impaired borrowers 16

Our paper corroborates the growing concern that zombie firms may be holding back growth in a number of countries, including Japan (Caballero, Hoshi, and Kashyap, 2008), and Europe (Acharya et al., 2019, Gopinath et al., 2017). Blattner, Farinha, and Rebelo (2019) examine the relationship between weak banks and low productivity growth following the European sovereign debt crisis while Gropp et al. (2020) focus on the productivity impact of distressed bank recapitalization through TARP during the global financial crisis. ${ }^{17}$ Banerjee and Hofmann (2018) and Caballero, Hoshi, and Kashyap (2008) show that zombie-firm presence lowers investment and employment in more productive firms ${ }^{18}$ In addition to the industry and bank congestion effects, our paper suggests that impaired borrowers may have

\footnotetext{
${ }^{16}$ Indirect means of forbearance include beneficial restructuring, maturity extension or conversion of the payment structure ranging from regular installments to a lump-sum payment at maturity, and may be more prevalent in developing countries like India.

${ }^{17}$ Consistent with the cleansing recessions hypothesis, Gropp et al. (2020) show that regions with higher regulatory forbearance during the crisis experienced slower productivity growth with depressed job creation, employment, and wage growth.

${ }^{18}$ Further, Banerjee and Hofmann (2018) emphasize that there may be a policy dimension to this problem including structural policy weaknesses, e.g., inadequate insolvency regimes, bank forbearance, loose monetary policy and impaired banking systems, and the persistence of crisis-induced support to small and medium enterprises.
} 
used the new loans to repay existing loans, as well as their wage bill at the expense of capital expenditures. We find that regulatory forbearance is associated with depressed wage growth and capital expenditures for healthy firms.

Importantly, we show that the effects of forbearance are persistent and do not revert once forbearance measures are retracted. This is consistent with models where frictions in the creative destruction processes also predict weak recovery (Caballero, 2007; Caballero, Hoshi, and Kashyap, 2008). We show that forbearance measures may fundamentally change bankfirm relationships within industries by altering the composition of credit to zombie versus healthy firms. We also contribute to the novel literature on tackling zombie firms in the economy through increased bank supervision (Bonfim et al., 2020) and improved insolvency regimes (Andrews and Petroulakis, 2019).

Our paper is related to recent papers focusing on the ongoing banking crisis in India. We show that the perverse effects of forbearance were concentrated in state-owned banks. Since the forbearance schemes based on provisioning requirements apply to all banks and not just state-owned banks, the compromised standards can also lead to deterioration in balance sheets of private sector banks. In a contemporaneous paper, Flanagan and Purnanandam (2020) show that private sector banks with more distant and passive investors have a higher propensity to hide bad loans. The analysis in Flanagan and Purnanandam (2020) overlaps with the withdrawal phase studied in this paper and focuses on the clean-up phase which forced banks to recognize bad loans.19.

Finally, our paper is related to the literature that analyzes the impact of bailouts on bank lending. For example, Cong et al. (2019) show that implicit government guarantees for state-connected firms become more prominent during recessions, while Laeven and Valencia (2018) provide evidence that banking crises last longer in the presence of bank guarantees. Our paper examines the implicit guarantees embodied in regulatory forbearance measures especially for government-owned banks.

\footnotetext{
${ }^{19}$ Chopra, Subrahmanian, and Tantri $(2020)$ focuses on the clean-up phase as well emphasizing the impact of under-capitalization on lending patterns.
} 


\section{Regulatory Forbearance and The GFC}

This section describes the asset quality forbearance policy implemented by the Reserve Bank of India (RBI). We begin by describing the forbearance policies that were put in place in the midst of the Global Financial Crisis. Broadly, we divide the forbearance policies into two sub-periods: a period of increasing forbearance between August 2008 and May 2013 and a period with declining forbearance between May 2013 and February 2018 when forbearance measures introduced in the previous years were significantly withdrawn. The online appendix also briefly describes the evolution of the legal framework that banks can access to resolve non-performing or stressed loans.

\subsection{The GFC, Regulatory Forbearance and Regulatory Arbitrage}

Before 2008, loans in good standing were classified as standard assets and subject to a capital requirement of $0.25 \%-1 \%$ (Table A). The provisioning requirements for standard assets depends on the industry sector of the loan and hence there is a range of provisioning rates across industries. Loans that missed principal and/or interest payments were immediately classified as a sub-standard asset and subjected to a higher capital provisioning rate of $10 \%$ up to a one year period. If an asset continued in the sub-standard category beyond one year, it was downgraded further into the doubtful and then loss categories with progressive increases in provisioning rates to account for the steady deterioration in asset quality. Table A shows the different provisioning rates based on the alternative categories of loans in 2008. ${ }^{20}$

\footnotetext{
${ }^{20}$ These provisioning rates have been gradually increased since 2008. The most recent rates (as of July 1st, 2015) are $15 \%$ for sub-standard category, $25 \%$ for doubtful assets upto one year \& $40 \%$ for assets in doubtful category from one to three years. The latest notice pertaining to provisioning norms can be found in Master Circular - Prudential Norms on Income Recognition, Asset Classification and Provisioning Pertaining to Advances (2015). https://rbidocs.rbi.org.in/rdocs/notification/PDFs/ 101MC16B68A0EDCA9434CBC239741F5267329.PDF
} 
Table A: Provisioning Requirements by Loan Category in 2008

\begin{tabular}{llc}
\hline Asset Category & NPA Duration & Provisioning Rate \\
\hline Standard & & $0.25 \%-1 \%$ \\
\hline Sub-Standard & $<12$ months & $10 \%$ \\
\hline Doubtful & 12 to 24 months & $20 \%$ \\
& 24 to 48 months & $30 \%$ \\
& $>48$ months & $100 \%$ \\
\hline Loss & & $100 \%$
\end{tabular}

Notes: Provisioning requirements by loan categories as defined by the Reserve Bank of India.

As a precautionary measure, and potentially to address the emerging crisis in the infrastructure sector, the Reserve Bank of India announced a "Special Regulatory Treatment" for the restructuring of debt in 2008. Asset quality forbearance was designed to provide temporary liquidity relief to otherwise solvent firms due to GFC-related adverse shocks to the cash flows of firms. Under the terms of this new regulation, lending institutions were no longer required to automatically downgrade the asset quality of a loan to the sub-standard category due to missed payments of principal or interest or both. If banks could claim that a firm had missed payments because it was facing temporary liquidity difficulties during the crisis, they could classify the loan assets into the new 'restructured' category that was not subject to the higher provisioning rates. Under normal circumstances, the loan would be downgraded to the sub-standard category and capital provisioning requirements would increase proportionately.

Not surprisingly, banks took full advantage of the 'restructured' classification to avoid the higher provisioning requirements. Forbearance steadily provided banks with a route to postpone or all together avoid the recognition of troubled assets (Vishwanathan, 2018). The restructured classification was used to engage in regulatory arbitrage, a phenomenon sometimes referred to as 'extend and pretend', deviating sharply from the original intent of the forbearance policy, namely, to provide temporary relief for otherwise viable firms who were 
encountering liquidity issues during a crisis.

By 2013, restructured assets constituted nearly 70\% (50\%) of stressed assets for public (private) commercial banks, respectively (Figure 17). The non-performing to gross asset ratio in Figure 10 mirrors the pattern. As restructured or hidden assets rose with the announcement of forbearance, the non-performing asset ratio declines. Similarly, the ratio of distressed assets (defined as the sum of non-performing and restructured assets) was relatively flat during the forbearance period and increases sharply after the withdrawal is announced-distressed assets had, however, started increasing for public banks by 2011 (Figure 1 c). Taken together the patterns in the three panels of Figure 1 suggest that the evolution of the hidden asset ratio masked the true extent of deterioration of bank loan portfolios. We see that once the withdrawal of forbearance was announced in 2013, the restructured to distressed assets ratio begins to decline while the ratio of non-performing and distressed assets increases sharply. We discuss the construction of these measures in greater detail in Section 3.1.2.

A Financial Stability Report from the RBI notes that while regulatory forbearance may be justified during major crisis periods, forbearance for extended periods of time potentially lead to moral hazard problems (Financial Stability Report (Including Trend and Progress of Banking in India 2013-14), 2014). It also noted that as India moved towards implementing Basel II norms, accounting discretion such as restructuring would subsequently have no impact on capital requirements. In May 2013, the RBI announced that forbearance on asset classification would be withdrawn effective April 1, 2015.

\subsection{Regulatory Forbearance: The Withdrawal Phase}

Between 2013 and 2017, the RBI together with the government began tightening the prudential norms for asset classification and income recognition. However, some windows of restructuring remained open. Raghuram Rajan, Governor of the RBI initiated an 'Asset Quality Review' (AQR) that led banks to the recognize the non-performing nature of several loans, previously considered as restructured assets under the forbearance regime. During 
this time we see a significant increase in the proportion of non-performing assets in the gross loans of banks. Noticeably, its only after 2015, the AQR implementation year, that the proportion of restructured assets in gross loans finally starts declining. Figure 1 provides visual confirmation of the use of forbearance regulations to hide the stressed loans under the guise of 'restructured' assets. ${ }^{21}$

Forbearance measures can therefore be broadly classified into two phases, a phase starting August 2008 and ending May 2013 where forbearance increased and a second phase beginning May 2013 and ending February 2018 when forbearance was completely removed. Table A1 summarizes the major policy events and the direction of increases and decreases in forbearance over our sample period. Our analysis ends in the first quarter of 2016 to avoid the confounding effects of the the Insolvency and Bankruptcy Code introduced in May 2016, which significantly altered the bad loan resolution process and importantly to avoid contaminating our results with the demonetization episode that began in November 2016.

\section{Data}

We use firm-level data from the Prowess database and bank-level data from the DBIE database of Reserve Bank of India. Prowess covers both publicly listed and unlisted firms from a wide cross-section of manufacturing, services, utilities, and financial industries from 1989-2019. About one-third of the firms in Prowess are publicly listed firms. The companies covered account for more than $70 \%$ of industrial output, $75 \%$ of corporate taxes, and more than $95 \%$ of excise taxes collected by the Government of India (CMIE).

The advantage of detailed balance sheet and income statement data at the firm level is the information it provides on a number of variables, such as sales, profitability, and assets. Prowess also provides information on the identity of banks from whom firms borrow. However, coverage of balance sheet items for these banks tends to be sparse in Prowess, so

\footnotetext{
${ }^{21}$ Other measures implemented include the creation of a data warehouse of large loans called as Central Repository of Information on Large Credits (CRILC) that covers all loans in India over Rs. 5 crore (approximately US\$ 0.7 million). The database is accessible to all the banks and provides a transparent way for banks gain information about whether a borrower has defaulted with another bank.
} 
we hand-match the bank-identities to detailed information on bank balance sheets from the RBI's DBIE database.22

Our forensic approach matching firms to banks has a major advantage. Financial secrecy laws prohibit banks in India from revealing the identity of their borrowers ${ }^{23}$ However, there is no such restriction on firms voluntarily revealing their bankers. To conduct our empirical analysis, we take advantage of this asymmetry in information sharing to build a bridge from the firm- to bank-level data.

The data from Prowess combined with the DBIE data are particularly well-suited for understanding how banks and firms adjust over time and how their responses may be related to policy changes such as the forbearance policy. Prowess provides the names of banks for about 19,600 firms. After applying the mentioned filters, our sample has 8,331 unique firms. $36 \%$ of the firm-year observations have a single banking relationship and rest have multiple banks. The average number of bankers among multiple banking firms is 4.86 over the sample period.

Prowess covers firms in the organized sector, which refers to registered companies that submit financial statements. According to the government, "the organized sector comprises enterprises for which the statistics are available from the budget documents or reports, etc. On the other hand the unorganized sector refers to those enterprises whose activities or collection of data is not regulated under any legal provision or do not maintain any regular accounts" ${ }^{24}$ The 1956 Companies Act requires Indian firms to disclose information on capacities, production, and sales in their annual reports. All listed companies are included in the database regardless of whether financials are available.

The Indian NIC system (2008) ${ }^{25}$ system classifies firms in the Prowess dataset by industry. The data include firms from a wide range of industries, including mining, basic

\footnotetext{
${ }^{22}$ When a firm borrows from more than one bank in year, the bank names are recorded in Prowess in the order in which they appear in the firm's financial statements. In the case of multiple banking relationships, we retain the first bank as it likely corresponds to the firm's lead bank.

${ }^{23}$ THE PUBLIC FINANCIAL INSTITUTIONS (OBLIGATION AS TO FIDELITY AND SECRECY) ACT, 1983. http://legislative.gov.in/sites/default/files/A1983-48.pdf

${ }^{24}$ For more details, refer to: Ministry of Labour and Employment (2000)

${ }^{25}$ See http://mospi.nic.in/classification/national-industrial-classification for further details.
} 
manufacturing, financial and real estate services, and energy distribution.

Another advantage of the bank- and firm-level data is that detailed balance sheet information allows us to analyze how the forbearance policy affects banks according to their loan portfolios of firms distinguished by solvency and liquidity status. The data allow us to compile a sample of non-financial Indian firms matched with their bankers so that the nature of matching can be explored using the borrower and bank level characteristics. Prowess also provides data on stock market returns and financial performance variables like current assets, current liabilities, debt, cash flows, interest expenses, and so on. We use the financial variables to construct firm-level measures of quality i.e. liquidity and solvency. We also use information on real variables like the change in gross fixed assets and the wage bill of a firm to examine the real effects of the forbearance policy changes.

We supplement the main analysis with loan-level data on loan charges from the Ministry of Corporate Affairs (MCA). These data are self-declared by firms and may or may not be validated by a formal audit. The data contain information about the loan amount and the financial institution name. We use the "date of modification" to construct whether a loan is restructured and the loan amount restructured. We match the loan-level data to the main Prowess data using the Company Identification Number (CIN). We hand match the data on scheduled commercial banks. The final dataset comprises matched firm-bank information on collateralized loans. Since the data is filed manually by companies and banks, there are numerous instances where, due to human error, there are duplicate observations in the data. We deal with these inaccuracies in the following way. Each charge has a unique charge identification number. We drop observations with duplicate charge identification numbers, or if the charge identification number is different, but loan amounts, bank names, and dates are the same. We take a conservative approach and drop observations where the date of loan initiation, loan amount, and the CIN appears more than once. We then aggregate up to the bank-firm-year level and form a balanced panel to get 1,298,440 observations.

We use a sample period from 2006-2016. We end the sample period in March 2016 to avoid confounding the results with the introduction of the Insolvency and Bankruptcy Code 
in May 2016 and the demonetization episode of November 2016. Throughout the sample we distinguish between the phase after introduction of forbearance in 2008 and the phase after withdrawal was announced in 2013.

Turning to the bank-level data, The firm-level data is matched with the bank-level information obtained from annual Bank Statistical Returns (BSR) available from the Reserve Bank of India's website. ${ }^{26}$ The publicly available version has bank-level balance sheet data and common variables such as industry classification, credit, deposits, NPAs, restructured advances, and so on.

Our baseline analysis includes public and private scheduled commercial banks. We extend the analysis to foreign banks for a placebo test in the robustness section. In 2016, there were 27 public sector banks, 21 private sector banks and 49 foreign banks in the Indian banking system 27 Public sector banks account for almost $70 \%$ of the total market share, private sector banks for approximately 23\%, and foreign banks for the remaining 7\%. Figure 2 shows that asset quality has declined significantly post-2013 and more so for public sector banks. With this motivation, we restrict our sample of lenders to public and private sector banks. We construct bank-level measures of performance using the DBIE's BSR dataset.

The fiscal year for a vast majority of Indian firms ends in March. A subset of firms release data on a quarterly basis as well. The bank-level data is released at the end of March every year. To ensure that we use the latest available information about each firm we use the latest date in a financial year for firms' financial variables. We exclude observations with missing values for total assets, a central variable required for computing several variables used in our main analysis. Table A2 provides a detailed summary of variable definitions. Table A3 reports the steps we follow to construct our sample for the period 2006-2016. The final sample is at the firm-lead-bank-year level comprising 38,016 observations, 8331 unique firms and 39 unique lead banks.

To identify zombie firms, we require a minimum benchmark lending rate for prime bor-

\footnotetext{
${ }^{26}$ Following is the link to DBIE portal of RBI https://dbie.rbi.org.in/DBIE/dbie.rbi?site=publications $\# ! 4$

${ }^{27}$ In addition there were 56 regional rural banks, 1,562 urban cooperative banks and 94,384 rural cooperative banks, and cooperative credit institutions-these banks are excluded from our analysis as they do not lend to the firms in our sample.
} 
rowers. We use the Prime Lending Rate (PLR) charged by State Bank of India as the benchmark minimum interest rate. The prime lending rate is the rate at which banks are willing to lend to highly-rated borrowers. We use the minimum prime lending rate as a conservative estimate of the interest rates at which only the most creditworthy borrowers can borrow. In the robustness tests, we consider a narrower definition of zombie-firms that adds a low interest coverage ratio $(I C R<2)$ filter to the subsidized credit filter. This definition demonstrates that the borrowers we classify as zombies are able to obtain credit at subsidized rates even when their debt servicing capability is not strong.

\subsection{Constructing Borrower and Bank-Level Measures}

In the formal analysis, we examine both bank and borrower-level responses to the forbearance policy to assess whether bank lending to low-quality firms changed and whether banks used the asset classification benefits to their advantage. In other words, did the forbearance provide an opportunity for regulatory arbitrage? Consistent lending increases to low-solvency and zombie firms following the announcement of forbearance could indicate that the firms were distressed due to fundamental economic problems and not due to temporary liquidity constraints. Next, we describe the construction of our borrower-level measures from the firm-level data and the bank-level measures.

\subsubsection{Borrower-Level Measures}

We begin with measures of borrower-level liquidity and solvency indicators. Liquidity ratios are based on the portions of the company's current assets and current liabilities taken from firm balance sheet and indicate the ability to repay short term obligations. We consider the Quick Ratio (Current Assets-Inventory/Current Liabilities) and the Cash Ratio (Cash to Current Liabilities) as measures of liquidity. The higher the value of these ratios, the more comfortable the firm is with respect to short term survival and cash availability.

The solvency measures indicate the long term survival potential of firms. To measure solvency, we use Debt-to-Equity Ratio, Debt to Assets ratio and Altman Scores using Emerg- 
ing Market weights. The Debt to Equity ratio signals the extent of leverage and measures the ability to repay long term obligations. The lower the ratio, the more comfortable is the leverage position of the firm. The measures are winsorized at $0.5 \%$ level on both ends of the tail for every year to avoid major outliers from biasing the averages.

\subsubsection{Bank-Level Measures}

At the bank level, we require a measure that can capture the effect of regulatory forbearance on the bank's portfolio of assets. We begin by constructing bank-level portfolios by first collapsing the matched bank-firm dataset at the bank level to compute the total number of borrowers attached to each bank. Next, we map the bank-level information from the RBI, namely, Gross Advances (GA), Restructured Advances (RA) and Non-Performing Advances (NPA) to our collapsed dataset by bank and year to compute the measures as follows.

We construct the 'Hidden Assets Ratio', or the proportion of restructured assets in the total pool of distressed assets of a bank. It is computed as the restructured assets as a proportion of restructured and non-performing assets on a bank's balance sheet $\left(\frac{R A}{D A}\right)$. Given that more granular level data is not available for tracking the overtime evolution of loans across the different loan classification categories like standard and non-standard ${ }^{28}$ we use this measure with the caveat that this is an overestimate of the potential hiding of bad loans by banks in India. For the purpose of our analysis, we define Distressed Assets as the sum total of non-performing loans (NPAs) and restructured loans (RA) in any given year. This is the proportion of potentially bad loans hidden as RAs and declared bad loans as NPAs by banks. We compute the measure as the fraction of restructured assets and non-performing assets as a proportion of gross advances by the bank $\left(\frac{D A}{G A}\right)$. Similarly, we compute the NPA ratio as the ratio of non-performing assets to gross advances $\left(\frac{N P A}{G A}\right)$.

\footnotetext{
${ }^{28}$ On an annual basis, the RBI publishes the aggregate volume of loans in the standard and NPA categories for each bank but does not disclose how an individual loan transitions over years from one category to another. We also do not know at the firm level that if that firm's loan has been classified as NPA.
} 


\subsection{The Data at First Glance}

Table 1 shows the summary statistics for the selected firm level and bank level ratios used in our analysis. We present the statistics for high and low quality borrowers by: solvency, liquidity and zombie status. We also test for the significance of the difference in means between the high and low quality groups. Panel A shows the summary statistics by solvency and liquidity status. We observe that firms classified as low-solvency have significantly lower liquidity measures and significantly higher debt compared to solvent firms. Similarly, lowliquidity firms also have significantly lower-solvency measures and lower aggregate debt levels compared to the liquid firms.

Panel B splits the sample via zombie status. We use three alternative definitions of zombie firms. First, we capture the firms that are recipients of subsidized credit (Zombie Status \#1). Second, we impose an additional condition of an interest coverage ratio below two (Zombie Status \#2). Third, we also examine a subset of firms classified as 'speculative credit' defined by the IMF (Zombie Status \#3). More detailed explanations follow in Section 5. Zombie firms have significantly higher aggregate debt levels and leverage ratios along with lower interest coverage ratios and liquidity ratios compared to the creditworthy firms in the sample. An interesting observation is that the Zombie Status \#1 and \#3 definitions of low-quality firms do not depend on average interest rate paid by a firm. Perversely, these definitions indicate a significantly lower cost of borrowing for low-quality firms compared to healthy firms. We infer that low-quality firms had cheaper access to credit during our sample period despite their low-solvency and liquidity status.

In the formal empirical specifications, low-solvency firms have above-median debt-toequity ratios and low-liquidity firms have below-median cash ratios. Zombie firms are defined as borrowers who receive subsidized credit; i.e. they pay an average interest rate below that paid by most creditworthy borrowers in the economy.

Table 1. Panel C shows descriptive statistics for the bank-level data by bank health status. Stressed banks are on average smaller and have higher proportions of restructured and non-performing loans compared to healthy banks. As also mentioned in Section 3, 
Figure 2 plots the evolution of bank-level distressed and restructured asset ratios between 2006-2016, further split by ownership, into public and private banks. Panel A shows the restructured assets ratio $\left(\frac{R A}{D A}\right)$ steeply rising post 2008 until 2013 indicating that banks used the forbearance policy heavily, reflected in the rising levels of restructured loans. Panel B plots the distressed assets ratio $\left(\frac{D A}{G A}\right)$ increasing significantly post-2008 and continuing to do so in the post-2013 period indicating the rapidly rising levels of distressed loans. Panel C displays the non-performing assets ratio $\left(\frac{N P A}{D A}\right)$, the proportion of loans recognized as bad loans. The ratio hovered at relatively low levels till 2013 following which it spikes up pretty quickly indicating a transfer of restructured assets to the non-performing category (i.e., from Panel A to Panel C). By 2016, NPAs were almost 10\% of total loans in the Indian banking sector-significantly higher than other emerging markets. Also note that the non-performing loans are significantly higher for public sector banks compared to private sector banks.

Using simple uni-variate regressions, Table 2 displays the correlation between the proportion of low-liquidity and low-solvency firms in bank's portfolio and the distressed asset ratio of the bank in between 2006-2016. We present regression coefficients for $\frac{D A}{G A}, \frac{R A}{D A}$ and $\frac{N P A}{G A}$ against different measures of low-solvency and low-liquidity. Solvency measures are based on debt-to-equity ratios and liquidity measures on the cash ratio.

The first two rows measure the proportion of firms in a bank's portfolio with above median leverage ratios and in the top quartile. The third row, focuses on a leverage ratio above 2, an accepted definition of leverage that is 'too high'. The last three rows focus on low-liquidity firms and measure the proportion of firms in a bank's portfolio with a cash ratios in the bottom quartile, below median, and below unity respectively.

The data suggest that there is a consistent pattern of statistically significant and positive correlations between the bank-health measured by the ratio of stressed assets and low-quality borrowers measured by low-liquidity and low-solvency. The evidence in Table 2 provides preliminary evidence for the hypothesis that there is a time-invariant sticky match between stressed banks and low-quality borrowers.

Further, Table 3 displays confusion matrices based on the three firm characteristics of 
liquidity, solvency and zombie-status, and by bank-health status. The matrices uncover some interesting lending pattern differences across stressed and healthy banks. Stressed-banks tend to lend more heavily to to low-solvency, low-liquidity and zombie credit firms compared with their healthy counterparts. The proportion of high solvency/low-liquidity firms and lowsolvency/low-liquidity firms is significant. While low-liquidity firms constitute the 'intended' beneficiaries of the policy, low-solvency firms constitute the 'unintended' beneficiaries. We also see that the loan portfolios of stressed banks comprise a higher proportion of low-quality firms signaling a mis-allocation of credit.

Figure 2 presents a graphical description of the time-series patterns in lending by stressed and healthy banks. Panel A shows a rapid expansion in the aggregate credit extended by stressed compared to healthy banks. However, if the increase in lending by stressed banks was comprised of creditworthy borrowers, then the credit expansion may be less of a concern. A visual inspection of the data reveals how aggregate credit was apportioned between borrowers by quality status based on alternative criteria such as zombie-status (Panel B), solvencystatus (Panel C) and liquidity-status (Panel D).

We see that the credit extended to zombie firms shows a steep and sustained increase after 2008. While lending to creditworthy firms declines sharply following the forbearance withdrawal announcements by the RBI, no such reversal appears in lending to zombie firms following forbearance retraction. Similarly, lending to low-solvency firms consistently increases relative to 2008-levels along with a very apparent decline in credit extended to solvent firms. Credit increases to low-solvency firms appear to moderate around the forbearance withdrawal announcement alongside increases in credit allocations to solvent firms.

Finally, we fail to observe a striking difference in the credit allocated to firms by liquidity status, although there is somewhat of a decline in credit extended to liquid firms following forbearance withdrawal. Overall, the patterns of credit allocation by firm-health status are puzzling especially given that the original forbearance policy allowances were intended specifically to address the needs of firms experiencing temporary liquidity stress. In the next section, we formally investigate the empirical validity of the patterns observed in Table 3 
and Figure 2 .

\section{Benchmark Specification and Results}

A visual inspection of the data suggest that following the implementation of forbearance measures lending increased to the 'intended' beneficiaries low-liquidity but solvent firms. However, lending also increased to the 'unintended' beneficiaries, the low-liquidity and lowsolvency firms. Further, there appears to be a time-invariant sticky match between stressed banks and low-quality firms including those in zombie status. In this section, we formally investigate the relationship between bank-lending and firm-health status to investigate whether asset quality forbearance impacted the efficiency of credit allocation.

\subsection{Firm-level Borrowing}

To formally examine the significance of the patterns observed in Figure 2, we first test whether lending to low-solvency borrowers increased following the implementation of forbearance measures. Specifically, we explore whether there is any evidence for a sticky match between stressed banks and low solvency borrowers. Following Acharya et al. (2019), we use triple-interaction specifications for our variables of interest. We estimate the following pooled specification:

$$
\begin{aligned}
& \log \left(\text { Debt }_{j, t+1}\right)=\alpha_{t}+\gamma_{j}+\beta_{1} * \text { Stressed Bank }_{b} * \text { Low Solvency }_{j, t} \\
& +\sum_{k=1}^{2} \delta_{k} * \text { Stressed Bank }_{b} * \text { Forbearance }_{t}^{k}+\sum_{k=1}^{2} \eta_{k} * \text { Low Solvency }_{j, t} * \text { Forbearance }_{t}^{k} \\
& +\sum_{k=1}^{2} \zeta_{k} * \text { Stressed Bank }_{b} * \text { Low Solvency }_{j, t} * \text { Forbearance }_{t}^{k}+\epsilon_{j, t+1}
\end{aligned}
$$


Observations are at the firm-level and each firm is linked to a lead bank 29 We classify a bank as stressed, Stressed Bank $k_{b}$, if the proportion of non-performing loans in the total gross advances lent by a bank is in top two terciles in 2007, i.e., prior to forbearance provision by the RBI. It is noteworthy that there is substantial overlap between the subset of banks classified as stressed, based on their 2007 NPA ratio, and the set of banks placed under the RBI's Prompt Corrective Action framework between February 2014 and January 2018. The Reserve Bank specified certain regulatory trigger points based on the capital to risk-weighted assets ratio (CRAR), the net non-performing assets (NPA) and Return on Assets (RoA), to initiate certain structured and discretionary actions when banks crossed these thresholds (Annex 4: Prompt Corrective Action (PCA) Framework, 2014).

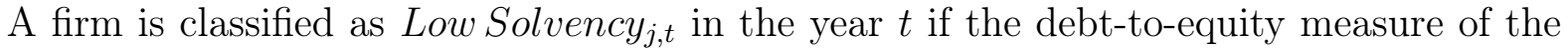
firm in time period $t$ is above median. A firm is classified as Low Liquidity Lin in the year $t$ if the cash ratio measure of the firm in time period $t$ is below median. The indicator variable Forbearance $^{k}=1$ takes a value of 1 in the years following 2008, i.e., after the introduction of forbearance and Forbearance ${ }^{k}=2$ takes a value of 1 post 2013, i.e., after the forbearance withdrawal announcement by the RBI. All specifications control for time-invariant borrower characteristics and time-varying firm size using log sales.

The pooled estimation strategy allows us to test the effects of the introduction and withdrawal of forbearance in the same regression specification. Our primary interest lies in the interaction coefficients, $\zeta_{1}$ and $\zeta_{2}$. The triple interaction coefficient $\zeta_{1}$ represents the correlation between the the outcome variable, the level of debt, $\log \left(\operatorname{Debt}_{j, t+1}\right)$, and stressed bank lending to low-solvency firms over the entire post-forbearance, 2009-2016. Note also that $\zeta_{1}$ estimates the baseline effect during the forbearance phase as it represents the marginal change in lending to low solvency firm $j$ by a stressed bank $b$ following the introduction of forbearance. $\zeta_{2}$ measures the incremental effect during the withdrawal phase. In all the regression specifications, we control for the main and pairwise and interaction terms if they are not absorbed by the fixed effects. For brevity we omit these interaction terms in the

\footnotetext{
${ }^{29}$ The Prowess data do not provide information on lending by each bank-firm pair and hence we link firms to a lead bank.
} 
table displays.

Columns 1 and 2 of Table 4 summarize the results. On average, we observe a positive and statistically significant coefficient of 0.384 in lending to low-solvency firms by stressed banks during the phase of increasing forbearance. To gain a more granular understanding of the significance of lending to low-solvency versus creditworthy firms, we compute marginal effects. We compare the difference in margins when the solvency status changes from 0 to 1 at $($ Stressed bank $=1$, Post Forbearance $=1)$ and at (Stressed bank=0, Post Forbearance $=1)$. The difference in margins indicates that lending to low-solvency firms by stressed banks is $7 \%$ higher than to creditworthy firms. The coefficient $\zeta_{2}$, that measures lending to low-solvency firm $j$ by stressed bank $b$ in the withdrawal phase (2014-2016) is insignificant. Our prior was that the retraction of forbearance would curb lending to low-solvency firms. However, the insignificant coefficient $\zeta_{2}$ signals a sticky match between stressed banks and low-quality borrowers after forbearance withdrawal, indicating the potentially persistent effects of having provided forbearance to begin with.

Next, we examine the impact of forbearance on liquidity-constrained firms. We estimate the following pooled specification:

$$
\begin{aligned}
& \log \left(\text { Debt }_{j, t+1}\right)=\alpha_{t}+\gamma_{j}+\beta_{1} * \text { Stressed Bank }_{b} * \text { Low Liquidity }_{j, t} \\
& +\sum_{k=1}^{2} \delta_{k} * \text { Stressed Bank }_{b} * \text { Forbearance }_{t}^{k}+\sum_{k=1}^{2} \eta_{k} * \text { Low Liquidity }_{j, t} * \text { Forbearance }_{t}^{k} \\
& +\sum_{k=1}^{2} \zeta_{k} * \text { Stressed Bank }_{b} * \text { Low Liquidity }_{j, t} * \text { Forbearance }_{t}^{k}+\epsilon_{j, t+1}
\end{aligned}
$$

Once again, the triple interaction coefficients $\zeta_{1}$ and $\zeta_{2}$ are of interest. $\zeta_{1}$ measures the marginal change in lending to the average liquidity-constrained firm, $j$, by stressed bank, $b$, in the forbearance phase. Columns 3-4 of Table 4 summarize the results. We observe a positive and significant coefficient of 0.306 . The finding is robust to controls for time-invariant bank and borrower characteristics as well as year effects. A margins computation of the difference 
in lending by stressed banks to low-liquidity firms is approximately $4 \%$ higher. $\zeta_{2}$, withdrawal phase lending by stressed banks to liquidity-constrained firms is statistically insignificant, similar to the finding about solvency. The statistical insignificance of $\zeta_{2}$ is consistent the hypothesis of persistence in lending patterns following forbearance retraction.

Given the considerable overlap between the low-liquidity and low-solvency firms, Table IA.4 partitions the firms in our sample into four categories based on their liquidity and solvency status. The forbearance policy was designed to sustain solvent borrowers facing temporary liquidity stress. The patterns in Columns 1 and 2 however do not indicate a significant change in the loans extended to illiquid firms that are otherwise solvent, in theory, the intended beneficiaries of forbearance policy. Perversely, the data suggest that credit was allocated away from these firms. Further, leverage grows by $25 \%$ for borrowers in the lowsolvency and low-liquidity category (Column 4). This finding further illustrates a pattern of credit misallocation by stressed banks consistent with risk-shifting and a gambling for resurrection narrative.

\subsection{Zombie Lending}

Andrews and Petroulakis (2019) explore the connection between 'zombie' firms, firms that would typically exit in a competitive market, and bank health. Indirect means of forbearance can include beneficial restructuring, maturity extension or conversion of the payment structure from regular installments to a lump-sum payment at maturity, and may be more prevalent in emerging countries like India. McGowan, Andrews, and Millot (2018) argue that, perversely, it became easier for weak firms that do not adopt the latest technologies to remain in the market, while more productive firms are less likely to expand. Further, their study emphasizes the policy dimensions to the observed patterns, including structural policy weaknesses (e.g., inadequate insolvency regimes), bank forbearance, loose monetary policy and impaired banking systems, alongside persistent crisis-induced support to small and medium enterprises. In addition, there is a growing concern that zombie firms may be holding back potential growth in a number of countries, including Japan (Caballero, Hoshi, 
and Kashyap, 2008), the United Kingdom (Acharya et al., 2019), and Southern Europe (Gopinath et al., 2017).

Much of the literature attributes the rise of zombie credit to weakening banks capital ratios (Acharya et al., 2019). A popular measure of bank capital is the Tier-I Capital to the Risk Weighted Assets Ratio (CRAR-T1). CRAR-T1 consists of the first line of defense for a bank in wake of any losses. We plot the proportion of zombie borrowers against the Tier 1 capital ratio of the average bank in our sample. Figure IA.2 shows an inverse relationship between bank capital adequacy and the proportion of zombie borrowers. An interpretation of the observed pattern is that if banks' balance sheets were under stress in the midst and aftermath of the great financial crisis, banks may have faced a perverse incentive to lend to zombie borrowers by evergreening loans-a phenomenon referred to as 'extend and pretend.'

In the case of India, the regulator enabled such lending by allowing regulatory forbearance which happened against a backdrop of increasing capital requirements. Bearing in mind the worsening interest coverage ratio of low-quality borrowers in our sample, coincident with declining bank health and forbearance provision, we test for the prevalence of zombie lending in our data. We focus on whether a match exists between zombie firms and stressed banks. Further we explore whether zombie lending adversely affecting healthy firms in their ability to borrow, especially if stressed banks also dominate lending in particular industries. If so, healthy firms may be crowded out and the spillover effects of zombie lending could reduce healthy firm access to to bank credit.

Identification of zombies: Before turning to formal hypothesis testing, we briefly discuss alternative methods to identify zombie firms from the literature. The seminal approach in Caballero, Hoshi, and Kashyap (2008) defines zombie firms as those potentially receiving subsidized bank credit. More specifically, comparing actual interest payments made by firms with an estimated benchmark interest rate based on the firm's debt structure and market interest rates allows for the classification of zombie firms.

McGowan, Andrews, and Millot (2018) base their classification of zombies on the interest coverage ratio. A choice that is based on the fact that interest coverage ratios encompass 
channels other than subsidized credit through which zombie firms may be kept alive such as non-performing loans (NPLs), government guarantees to small and medium enterprises, and weak insolvency regimes. Acharya et al. (2019) classify firms as zombies if the following criteria are met: (i) subsidized credit access in year $t$, (ii) credit ratings derived from three year median are BB or lower, and (iii) the syndicate composition has either remained constant, or banks that left the syndicate were not replaced by new participants.

In the baseline specification, we follow the Caballero, Hoshi, and Kashyap (2008) definition of zombies. Specifically, we classify a firm as a Zombie if the firm received subsidized credit in time period $T$ i.e. the firm is able to borrow loans at an average interest rate that is lower than the Prime Lending Rate (PLR) of State Bank of India and has a debt-to-assets ratio $>0.15$.

Table IA.1 displays zombie-firm characteristics. Column 6 suggests that zombie firms are more likely to be in the manufacturing or infrastructure industry. This is consistent with the argument that the forbearance measures may have been directed towards helping failed infrastructure projects from the preceding lending boom period of 2002-2006 Zombie firms are also older, publicly-listed, and large. We are reassured that our zombie definition is not capturing small firms with high growth potential, that may not currently be able to service debt.

In addition to confirm that our results are robust to the zombie-firm definition, we use a set of alternative measures for classifying firms as recipients of 'zombie credit'. These include, (i) in addition to subsidized credit the borrower has an interest coverage ratio below two $(I C R<2)$, (ii) following Banerjee and Hofmann (2018) the borrower has $I C R<1$ consecutively for at least three years and below median Tobin's q in any given year in the industry to which it belongs. Tobin's q is a market-based measure and hence this sample is

\footnotetext{
${ }^{30}$ The origins of the trouble in the banking sector can be traced back to the credit boom between 2004 to 2009. Commercial credit nearly doubled and was accompanied by significant foreign capital inflows, especially in infrastructure and related sectors such as Telecom, Power, Roads, Aviation, and Steel (Chakrabarty, 2013a). By 2008, poor credit quality (Chakrabarty, 2013b) coupled with problems gaining access to land and environmental clearances, led to an increase in distressed assets, especially in the infrastructure sector (Chavan and Gambacorta, 2019, Chakrabarty, 2013a). Against this backdrop, the global financial crisis (GFC) occurred.
} 
restricted to listed borrowers, and (iii) the IMF's speculative credit definition i.e. firms with an interest coverage ratio, $I C R<4.1$ and a net debt-to-assets ratio greater than 0.25 .

The Impact of Forbearance on Zombie Lending and Spillovers: In line with the triple-interaction pooled regressions, we estimate the following specification to analyze borrowing by zombie firms in our sample:

$$
\begin{aligned}
& \log \left(\text { Debt }_{j, t+1}\right)=\alpha_{t}+\gamma_{j}+\beta_{1} * \text { Stressed Bank }_{b} * \text { Zombie }_{j, t} \\
& +\sum_{k=1}^{2} \delta_{k} * \text { Stressed Bank }_{b} * \text { Forbearance }_{t}^{k}+\sum_{k=1}^{2} \eta_{k} * \text { Zombie }_{j, t} * \text { Forbearance }_{t}^{k} \\
& +\sum_{k=1}^{2} \zeta_{k} * \text { Stressed Bank }_{b} * \text { Zombie }_{j, t} * \text { Forbearance }_{t}^{k}+\epsilon_{j, t+1}
\end{aligned}
$$

where $k=1$ post the introduction of forbearance and $k=2$ for withdrawal of forbearance.

Columns 1 and 2 of Table 5 summarize the results. We see a positive and significant coefficient $(0.31)$ on the triple interaction term, $\zeta_{1}$, on zombie lending by stressed banks in the forbearance period (Column 1). The positive and significant $\zeta_{1}$ rises slightly to 0.32 in the more robust specification with bank and year fixed effects (Column 2). The marginal effects computation shows that lending by stressed banks to zombie firms is $2 \%$ higher than zombie lending by healthy banks. The pattern of findings suggests that lending norms that were relaxed during the forbearance period stimulated lending by stressed banks to their existing low-quality borrowers and these new loans in all likelihood enabled zombie firms to service their older loans, i.e., forbearance facilitated the ever-greening of previous loans. Interestingly, zombie-firm borrowing from stressed banks does not fall significantly in the forbearance retraction period, $\zeta_{2}$ is not statistically significant. That the pattern does not appear to reverse following forbearance withdrawal indicates yet again the potentially persistent effects of policies that relax lending norms.

Next, we examine the dynamic effects of the forbearance policies on zombie lending using event study graphs by simply replacing the indicators for Forbearance ${ }_{t}^{k}$ in Equation 3 with 
an indicator for each time period. Figure 3 plots the coefficients for the triple interaction term. Consistent with the findings in Table 5, we see an increase in zombie lending in the forbearance phase but no evidence of a reversal during the withdrawal phase. The figure also suggests that the triple difference specification does not violate the parallel trends assumption. Figure 2 shows that the zombie and healthy borrowers may have been on different trends prior to the reform. However, our main specification compares the relative impact of lending to zombie and healthy borrowers by stressed banks against the same relative difference by healthy banks. While it is difficult to argue that stressed and healthy banks - or analogously zombie and healthy firms - were on similar trends prior to the crisis, it is plausible that the relative difference between zombie and healthy firms was similar at stressed and healthy banks. Indeed, Figure 3 suggests that the parallel trends assumption is not violated. Arguably, our estimates represent the causal impact of the forbearance policies on the zombie lending.

We also check the validity of our inferences using alternative refinements of the zombiefirm classification criteria. We present results in the Appendix Table IA.6 and Table IA.7. First, we add $I C R<2$ condition to the subsidized credit definition to ensure that the firms classified as zombies are indeed getting close to the point where they cannot service the interest costs on their borrowing (Table IA.6). Second, we employ the IMF's speculative credit definition in Table IA.7 which includes debt of all firms in the data set with an ICR of less than 4.1 and a net debt-to-assets ratio greater than 0.25 , where net debt is gross debt less cash 31 The thresholds are empirically established based on constituents of the global investment-grade and speculative-grade bond indices. Similar to our baseline measure, we see a statistically significant increase in zombie lending relative to non-zombie firms of $15 \%$ and $20 \%$ respectively using the alternative definitions. We find qualitatively similar results following Banerjee and Hofmann (2018)'s zombie-firm measure, however, while the coefficient estimates are qualitatively similar in sign, they are not statistically significant. Recall that this alternative definition requires information about Tobin's q that can only be calculated

\footnotetext{
${ }^{31}$ See the Global Financial Stability Report, October 2019: Lower for Longer, IMF
} 
for listed firms, while the subsidized credit definition maximizes coverage in our sample.

To discern whether the observed increase in zombie lending comes from bank supply-side or firm demand-side effects, we supplement the main analysis with data on restructured loans. We create a balanced panel at the firm-bank group-year level where bank group refers to stressed and healthy banks. Following Khwaja and Mian (2005), Table IA.8 disentangles the demand and supply-side channels by comparing the total amount of restructured loans made by stressed banks against those made by healthy banks for the same firm. Using the more stringent zombie definition that accounts for firm distress $(I C R<2)$ in addition to the baseline definition of subsidized credit, we see that the amount of restructured loans from stressed banks increased by 56 percent compared to healthy banks in the same firmyear (Columns 3 and 4). Similarly, there were more restructured loans to zombie firms from stressed banks relative to healthy banks. The coefficients in Columns 1-2 and 5-6 using the baseline subsidized credit and IMF's speculative credit zombie definitions, also show an increase in restructured loans, although the coefficients are imprecisely estimated ${ }^{32}$ Our results point to bank-supply side effects leading to an increase in zombie lending during the forbearance period.

We also see that there is a reversal in loan restructuring in the withdrawal phase. Zombie lending can occur in two ways. Banks can restructure loans, as was evident during the forbearance phase due to loan provisioning incentives. Banks can also evergreen loans by making new loans at subsidized rates to borrowers to pay off the old loans. Our zombie measure accounts for these differing incentives during the forbearance and withdrawal phases. Therefore, we focus on total zombie lending for the main analysis. While Table IA.8 documents that banks had lower loan restructurings in the withdrawal phase, Table 5 shows that zombie lending overall did not decline. Since loan provisioning incentives for restructured loans were removed in the withdrawal phase, it appears that banks simply shifted away from restructuring loans as a form of evergreening, but did not reduce overall zombie lending.

\footnotetext{
${ }^{32}$ A report published by the RBI (Report of the High Level Task Force on Public Credit Registry for India, 2008) notes that inaccuracies exist in the MCA data due to filing errors. The data need not be audited and is self-reported by firms. Firms can also delay the date of filing. All these factors can lead to measurement errors, biasing our estimates towards zero.
} 
Spillovers: Our findings thus far raise an important question. Does zombie-lending crowd out healthy firm access to credit? Credit access spillovers can occur in two ways. First, a direct channel through the bank-credit reallocation, banks can direct credit to zombie firms crowding out allocations to healthier firms, or the bank congestion channel. Second, an indirect channel that interferes with the creative destruction process (Caballero, Hoshi, and Kashyap (2008)), decreasing the demand for credit by healthy firms in the economy, the industry congestion channel.

To investigate the first channel, we test the bank-credit allocation hypothesis. That is, what happens to lending to healthy firms by stressed banks with higher proportions of zombies in their loan portfolios? To do so, we collapse the data to the bank level, and calculate the proportion of zombies in a bank's portfolio in a given year. We map this proportion back to the firm-level dataset and estimate the following baseline specification:

$$
\begin{aligned}
& \log \left(\operatorname{Debt}_{j, t+1}\right)=\alpha_{t}+\gamma_{j}+\beta_{1} * \text { Bank Frac Zombie }_{b, t} * \text { Healthy }_{j, t} \\
& +\sum_{k=1}^{2} \delta_{k} * \text { Bank Frac Zombie } \text { B }_{b, t} * \text { Forbearance }_{t}^{k}+\sum_{k=1}^{2} \eta_{k} * \text { Healthy }_{j, t} * \text { Forbearance }_{t}^{k} \\
& +\sum_{k=1}^{2} \zeta_{k} * \text { Bank Frac Zombie }_{b, t} * \text { Healthy }_{j, t} * \text { Forbearance }_{t}^{k}+\epsilon_{j, t+1}
\end{aligned}
$$

where $k=1$ for Introduction of forbearance and $k=2$ for withdrawal of forbearance.

Columns 3 and 4 of Table 5 summarize the results. The coefficient on the triple interaction term, $\zeta_{1}$ is negative and significant $(-1.062$ and -1.086$)$ in the baseline specification with and without bank-year fixed effects. The results suggest that as the proportion of zombie firm in the portfolios of stressed banks increases by 10\%, lending to healthy firms declines significantly, and is $10.6 \%$ lower than lending to zombie firms.

Using our baseline zombie definition of subsidized credit, in Table 5 we evaluate the indirect effects or spillovers from zombie lending to healthy firms via the bank-congestion channel. Using the full sample of banks, our first observation is that the proportion of firms classified as zombies in bank-loan portfolios is significant. The proportion of zombie firms 
in loan portfolios even at the 25 th percentile of zombie lending is approximately $42 \%$. This fraction is $47 \%$ for the sub-sample where the lead bank is stressed and $34 \%$ for the subsample where the lead bank is healthy. The high proportions of zombie firms in healthy bank portfolios is also noteworthy.

Next, we evaluate lending to healthy firms at the two points of reference, i.e., 25 th and 75th percentile values of the bank congestion measure for the full sample, and the subsamples evaluated at the full-sample coefficient $(-1.062)$. For the full sample, we find that as the zombie proportion in bank portfolios rises from the 25 th percentile value (42\%) to 75 th percentile value(58\%), the congestion effect intensifies from a $44 \%$ decline to a $61 \%$ decline in lending to healthy firms. The difference of a 17\% (61\%-44\%) marginal contraction in lending to healthy firms provides confirmatory evidence of the congestion in bank-lending due to zombie firms. Similar calculations for the sub-samples of stressed and healthy lead banks suggest marginal contractions amounting to an additional $13 \%$ and $14 \%$ as the proportion of zombie firms in loan portfolios rises from the 25 th to the 75 th percentile. ${ }^{33}$

To investigate the indirect channel, we examine the lending spillovers to higher quality borrowers in industries with higher proportions of zombie firms. First, to identify the granular industry classification we use the two-digit NIC codes in the Prowess data. We calculate the proportion of zombies in industry $h$ in year $t$ and classify the subset of firms that are not zombies, as healthy firms $j$. With this classification, we estimate the following baseline

\footnotetext{
${ }^{33}$ Using the two alternative definitions of zombie firms we find qualitatively similar coefficients for the bank congestion channel albeit statistically insignificant. An interesting observation using the alternative zombie definitions is that the coefficients that capture spillovers from bank congestion are statistically significant and negative in the withdrawal phase. This is suggestive of significant bank congestion, crowding out credit to healthy firms in the withdrawal phase as well, and no significant decline in the leverage of low-quality borrowers in the withdrawal period.
} 
specification:

$$
\begin{aligned}
& \log \left(\operatorname{Debt}_{j, t+1}\right)=\alpha_{t}+\gamma_{j}+\beta_{1} * \text { Industry Frac Zombie } \text { I }_{h, t} * \text { Healthy }_{j, t} \\
& +\sum_{k=1}^{2} \delta_{k} * \text { Industry Frac Zombie } \text { F }, t_{*} * \text { Forbearance }_{t}^{k}+\sum_{k=1}^{2} \eta_{k} * \text { Healthy }_{j, t} * \text { Forbearance }_{t}^{k} \\
& +\sum_{k=1}^{2} \zeta_{k} * \text { Industry Frac Zombie } e_{h, t} * \text { Healthy }_{j, t} * \text { Forbearance }_{t}^{k}+\epsilon_{j, t+1}
\end{aligned}
$$

where $k=1$ post the introduction of forbearance and $k=2$ for withdrawal of forbearance.

Columns 5 and 6 of Table 5 present the results. The coefficient on the triple interaction term, $\zeta_{k}$ which examines the debt levels of healthy firms, as the proportion of zombie firms in an industry increases during the forbearance period, is negative and statistically significant in the baseline specification with and without industry-year fixed effects $(-0.896$ and -0.693$)$.

Using our baseline zombie definition of subsidized credit, we now evaluate the indirect effects or spillovers from zombie lending to healthy firms via the industry-congestion channel. Similar to the summary statistics for the bank-congestion measure, for industries at the 25th percentile of industry-zombie-concentration, the proportion of firms classified as zombies is quite high at about $33 \%$ for the full sample. This fraction is $37 \%$ for the sub-sample where the lead bank is stressed and $32 \%$ for the sub-sample where the lead bank is healthy.

Next, we evaluate the lending to healthy firms at the two points of reference i.e. 25th and 75th percentile values of the industry congestion measure for the full sample, and the sub-samples evaluated at the full-sample coefficient (-0.896). For the full sample, we find that as the industry-zombie proportion rises from the 25 th percentile value $(33 \%)$ to 75 th percentile value(63\%), the congestion effect intensifies from a $29 \%$ to a $56 \%$ decline in lending to healthy firms. Thus, the difference is an additional $27 \%$ (56\%-29\%) contraction in lending to healthy firms is further evidence that an industry congestion channel is in operation. Similar calculations for the sub-samples of stressed and healthy lead banks suggest lending contractions of $23 \%$ and $25 \%$, respectively.

Using the refined definition of zombie firms that adds the $I C R<2$ criterion, we find 
that the triple interaction coefficient remains statistically significant. The decline in lending to healthy firms intensifies from $10 \%$ to $20 \%$ as the industry-level zombie fraction rises from the 25th to the 75 th percentile. The corresponding decline is along similar lines for the stressed bank sub-sample (10.5\% to $20.1 \%$ ) as well as for the healthy bank sub-sample $(9.9 \%$ to $18.9 \%$ ). We also employ the IMF's definition of speculative credit and replace the zombiefirm dummy with a dummy that takes the value of one if the firm has an $I C R<4.1$ and net debt-to-assets ratio greater than 0.25. Again, the triple interaction coefficient is statistically significant, albeit at the $10 \%$ level. The decline in lending to healthy firms intensifies from $11 \%$ to $24 \%$ as the industry fraction of zombie rises from the 25 th to the 75 th percentile. The corresponding decline is along similar lines for the stressed bank sub-sample (12\% to $25 \%$ ) and for the healthy bank sub-sample (11\% to $23 \%$ ).

The pattern of lending is of particular concern as we might expect healthy firms to regain access to credit once forbearance is withdrawn. To reiterate, we do not observe significant reversals in the patterns of lending to either low or high-quality borrowers when the withdrawal of forbearance is announced. Results from alternative definitions of zombie firms for the bank-congestion effect are qualitatively similar and the industry-congestion effects are robust across all three definitions.

The findings from the zombie-lending and spillovers estimations highlight the crowdingout effects of artificially propping up low-quality firms at the expense of their more creditworthy counterparts. If market forces of creative destruction were allowed to operate unfettered, inefficient and loss-making firms would exit allowing the fittest to survive. A perverse pattern appears to prevail instead - the evergreening of loans by stressed banks to zombie firms, and a reduction in the access to credit for healthy firms.

A potential concern is that the matching of large banks and large firms may be driving our findings. To address this concern, we divide the firms and banks matched into four categories based on the asset-size of banks and firms: big bank, small bank, big firm and small firm. We re-estimate our specifications for these four sub-samples but do not find a 
statistically significant matching relationship based on firm and bank size. ${ }^{34}$

Before turning to the real effects, Table IA.5 explores the ability of firms to substitute for bank credit by accessing corporate bond markets instead. Columns 1 and 2 show that zombie firms that can access the bond markets are not simply substituting away from corporate bonds. We find that even healthy firms with bond market access are unable to makeup the shortfall in bank lending by substituting into corporate bonds. The reallocation of credit from healthy to zombie firms can potentially impact real outcomes. In the next subsection we explore the real effects of forbearance on firm investment and employment patterns.

\subsection{The Real Effects of Forbearance}

To uncover evidence about the real effects of the forbearance policy, as a first pass, we examine firm investment and employment patterns. We compute real investment as the capex ratio $=\frac{\text { Capex }_{j, t+1}}{\text { Total Assetsj,t+1 }}$ where Capex $_{j, t+1}$ is the change in gross fixed assets between year $t$ and $t+1$. We measure employment expenses using the proportion of wages in the total expenses of firm i.e. $\frac{\text { Wages }_{j, t+1}}{\text { Total Expensesj,t+1 }}$.

We estimate the following specification for low-solvency borrowers:

$$
\begin{aligned}
y_{j, t+1}= & \alpha_{t}+\gamma_{j}+\beta_{1} * \text { Stressed Bank } k_{b} * X_{j, t} \\
& +\sum_{k=1}^{2} \delta_{k} * \text { Stressed Bank } k_{b} * \text { Forbearance }_{t}^{k}+\sum_{k=1}^{2} \eta_{k} * X_{j, t} * \text { Forbearance }_{t}^{k} \\
& +\sum_{k=1}^{2} \zeta_{k} * \text { Stressed Bank }_{b} * X_{j, t} * \text { Forbearance }_{t}^{k}+\epsilon_{j, t+1}
\end{aligned}
$$

where $y \in($ Capex Ratio, Wage ratio) and $X \in$ (Low Solvency, Low Liquidity); $k=1$ and $k=2$ are the introduction and withdrawal of forbearance, respectively.

Panel A of Table 6 summarizes the results for low-solvency borrowers. Columns 1 and 2 show that following forbearance provision, low-quality borrowers do not appear to increase their capital expenditures. In fact, capital expenditures by low-solvency firms that borrow

\footnotetext{
${ }^{34}$ Results are available on request.
} 
from stressed banks declines significantly during the forbearance phase. The findings in Columns 3 and 4 suggest that in addition to repaying existing loans, these low-quality borrowers may have used the new loans for wage payments. Noteworthy is the fact that once forbearance withdrawal is announced, wage expenditures decline.

Panel B of Table 6 summarizes the results for low-liquidity borrowers. We are unable to discern any statistically significant patterns in the capital expenditures or wage expenditures for low-liquidity firms in the forbearance or withdrawal periods. The overall pattern of results suggests that forbearance may have had the unintended consequence of supporting lowsolvency firms instead of firms facing temporary liquidity constraints as originally intended.

To examine the performance of zombie and healthy companies during the forbearance period, we replace the dependent variable with firm productivity in our benchmark specification. We use the Olley-Pakes method to estimate firm-level productivity using balance sheet variables. We find that the productivity of zombie-firms is, on average, $8 \%$ lower than healthy firms. This $8 \%$ difference in productivity represents $10 \%$ of the mean productivity in the sample. Turning to the spillovers channel, in industries with average fractions of zombie firms, the average productivity of a healthy firms is about $40 \%$ higher. We do not find significant differences in productivity between zombie versus healthy firms through the bank congestion channel.$^{35}$

\footnotetext{
${ }^{35}$ Results are available on request.
} 


\section{Robustness Checks and Alternative Tests}

In this section we explore alternative measures and motivations for forbearance and their impact on the credit allocation.

An Alternative Measure of Forbearance: Provisioning Rates. First, we establish that the provisioning requirements directly influenced bank incentives to engage in zombie lending. Table IA.10 examines the impact of provisioning requirements of restructured loans on zombie lending. Since restructured loans require lower provisioning compared to nonperforming loans, banks have an incentive to classify loans as restructured to ameliorate bank capital requirements.

Lowered provisioning rates on restructured loans may increase the attractiveness of zombie lending, while high provisioning rates imply lower gains from restructuring bad loans. The evidence in Table IA.10 suggests that there is a correlation between lower provisioning rates and an increase in credit to zombie firms. A 1\% lower provisioning rate on restructured loans corresponds to a 3\% increase in zombie credit (Column 2). Columns 3 and 4 also indicate that a $1 \%$ lower provisioning rate on restructured loans leads to a $9 \%$ decrease in credit to healthy firms via the industry congestion channel and $9 \%$ decline in credit via the bank congestion channel.

By replacing the forbearance and withdrawal phase binary dummies with a continuous measure of provisioning rates on restructured loans and directly capturing the regulatory arbitrage incentives, we confirm the baseline impact on zombie lending using an alternate measure of forbearance. The exercise also addresses the concern that given that forbearance and post-forbearance periods in the baseline specification coincide with the crisis and postcrisis years, we may simply be capturing effects on credit through firms' business cycle.

\section{An Alternative Definition of Bank Health: The Capital-To-Risk Weighted Asset}

Ratio. Provisioning requirements ought to bind more for weakly-capitalized banks since restructuring instead of recognizing bad loans, allows banks to avoid recognizing capital erosion. The baseline analysis uses the variation in bank health defined by the stressed 
asset ratio (NPAs). We repeat the baseline analysis using the capital-to-risk weighted assets ratio (CRAR) ratio. Table IA.9 replaces the time-invariant stressed bank dummy with a continuous time-varying measure of bank health captured by the CRAR ratio. Higher levels of CRAR indicate bank health and vice-versa. If banks with lower levels of CRAR engage in zombie lending we would expect to see a negative coefficient on the CRAR measure. Consistent with our baseline results, banks with $1 \%$ lower CRAR increase lending to low solvency and low liquidity firms (Columns 1-4) by $9 \%$. Column 6 indicates that banks with $1 \%$ lower CRAR increase lending to zombie firms by $7 \%$ during the forbearance period. As previously shown, these effects do not reverse post-forbearance.

Capital Inadequacy and State-Owned Banks Lax provisioning requirements may also allow the government to avoid costly recapitalization, especially of the state-owned banks of which they are the majority owners. Indeed, Figure 4 shows that post-forbearance the stressed assets share of state-owned banks relative to their total market share increased. In contrast, the ratio decline for private sector banks. Table IA.2 shows that the public sector banks engaged in greater zombie lending relative to their private sector counterparts (Columns 1 and 2). It appears the regulatory forbearance policy allowed state-owned banks to mask their capital inadequacy problems.

A Placebo Test: Foreign Banks. The baseline specifications exclude foreign banks under the assumption that their capital requirements are not sensitive to local forbearance measures in India. After 2014, foreign banks had the option to become wholly owned subsidiaries, however, prior to that they operated as branches. The hypothesis is that foreign banks are less sensitive to changes in local provisioning requirements because they are externally funded by their parent company or bank. We conduct a placebo test using the subset of foreign banks. Table IA.11 shows no impact on lending patterns in this sub-sample consistent with our priors. Foreign banks account for only $7 \%$ of the total market share of loans and hence the number of observations is reduced.

Alternative Lenders. We also examine whether the forbearance schemes necessitated firms to seek alternate lenders. Our previous results emphasize the possibility of a sticky 
match between low-quality borrowers and stressed banks and the consequent ever-greening of non-performing loans. Table IA.3 shows the results from a regression specification where the dependent variable is a binary indicator that classifies firms when they form a new relationship with a bank in period $T$ and did not have a relationship in the previous year.

Across the specifications, we find that healthy firms are $4 \%$ (Column 3) more likely to commence borrowing from private sector banks and $11 \%$ more likely to start borrowing from foreign banks. Plausibly, the forbearance schemes further worsen the perverse matching of stressed banks with unhealthy firms. The omitted group is public sector banks. In Column 1, healthy firms were $4.4 \%$ more likely to form a new banking relationship with private sector banks in the forbearance period. This effect declines during the withdrawal phase although the net effect of the forbearance and withdrawal phases is negative. Overall there is an increase in the switching behavior of healthy firms that perhaps explains the persistent patterns in lending to healthy firms that we document earlier in the paper.

\subsection{An Alternative Identification Strategy: Distance to Regulator}

We conclude by providing evidence using an alternate identification strategy based on proximity to the regulator (RBI). Thus far we conjecture that bank-level differences in responses to forbearance predict zombie-firm lending. The evidence also suggests that state-owned banks significantly drive zombie lending. The regulator's decision to provide forbearance to firms, and by extension to banks, is not exogenous to its expectations of output growth. Indeed, Agarwal et al. (2014) find that the higher the growth expectations, the more lax the supervisor. Forbearance can thus simply reflect the regulator's calculus that particular industries that receive forbearance have greater expected future returns, even if temporarily stressed.

A question also arises whether regulatory forbearance constitutes an implicit subsidy by the government and this may be more germane for state-owned banks. Forbearance policies were explicitly stipulated for illiquid firms and not intended to provide an opportunity for the evergreening of loans. However by relaxing the provisioning requirement for standard 
restructured assets, the government may have been able to provide an implicit subsidy thereby avoiding or delaying a more costly recapitalization needed to more comprehensively clean up state-owned bank balance sheets. It is also plausible that the regulator tolerated evergreening under pressure from the government to provide forbearance, especially with respect to state-owned banks.

To address potential endogeneity issues surrounding forbearance provision, we turn to an alternate identification strategy. Gropp et al. (2020) examine the impact of forbearance in the US in the aftermath of the GFC using the distance to the regulator, the Federal Deposit Insurance Corporation (FDIC), in Washington as an instrument for forbearance. We follow their strategy of and instrument for forbearance using the 'distance to the RBI.'

To examine the effect of the proximity to the regulator on lending, we replace the Stressed $\mathrm{Bank}_{b}$ indicator with a measure of proximity to the regulator (RBI) in our baseline specifications (equations $1-3$ ). Proximity to the regulator is equal to one if the distance of the bank headquarters is below the median value and zero otherwise. Table 7 presents the results for the subset of firms whose lead bank is a state-owned bank.

Using the proximity to the regulator as a proxy for forbearance, we find that lending to low-solvency firms increased by $33 \%$ (Column 2). Similarly, lending to low-liquidity firms increases by $26 \%$ (Column 4). Further, lending to zombie firms increases by $25 \%$. Note, that the provisioning requirements ensured that forbearance was available to all firms. State-owned banks can influence the regulator by lobbying for both the level of provisioning and for the industries brought under the provisioning requirements. Initially, provisioning requirements were relaxed for infrastructure projects, but soon after covered all firms. We argue that the laxity of the regulator is evident from whether forbearance was provided to liquid in contrast to insolvent firms, and in also to zombie firms. While evergreening is not officially condoned, the regulator can of course turn a blind eye.

Table IA.12 presents results for a subset of firms that borrow from private sector banks. We find no effect of proximity to the regulator for the private sector banks. This finding can also be viewed as a placebo test, confirming that the results in Table 7 are not driven 
by other features arising from the geographic location or proximity to Mumbai, the financial capital of India where the regulator is also located. Overall, the results in this section show that our results are robust to using an identification strategy based on proximity to the regulator as a measure of the degree of forbearance.

\section{Discussion and Concluding Remarks}

This paper provides evidence that the regulatory forbearance measures enacted by the Reserve Bank of India during the global financial crisis effectively handed over a license for banks to engage in regulatory arbitrage. We find that the forbearance measures provided banks with an incentive to hide true asset quality, and therefore the build-up of stressed assets in the system is a by-product of accounting subterfuge. Using both bank and firm-level data, we examine the externalities and costs generated by regulatory forbearance.

We show that indirect recapitalization schemes like forbearance in classification of stressed loans may have encouraged banks to channel debt to not only firms with low-liquidity but also to low-solvency borrowers. The significant increase in zombie firm lending has led to a significant misallocation of credit. Lending to healthy firms falls significantly in industries with higher proportions of zombies and by banks with higher proportions of zombie-borrowers. The results also signal the possibly persistent negative effects of prolonged phases of forbearance, hindering the process of creative destruction as impaired firms continue to survive at the expense of healthy ones.

Our findings imply that regulatory forbearance can function as an implicit subsidy from the government that postpones costly bank recapitalization. Asset quality forbearance in particular can allow banks to effectively "extend and pretend" distressed loans masking the underlying bank capital erosion. Loan-loss recognition would undoubtedly weaken bank balance sheets and warrant recapitalization.

The implicit subsidy has further significance in India's predominantly state-owned bank-

ing system. Given that state-owned banks comprise a nearly $70 \%$ share, recapitalization costs 
are unquestionably consequential compared to budget-neutral forbearance schemes. Acharya (2020) highlights forbearance as a form of fiscal dominance focused on postponing further stress on the sovereign's balance sheet entailed by costly bank recapitalization, especially when fiscal space is limited. We show in this paper that while bank balance sheets can look deceptively healthy, under-capitalized banks and zombie lending can impair the provision of credit to healthy firms in the economy further compromising the financial system.

In fact, subsequent efforts to correct for the zombie lending such as the bankruptcy law in 2016 had limited success in exacting banks to recognize non-performing loans (Kulkarni et al., 2020) and regulatory intervention efforts were, at best, partially effective. This paper shows that the sticky match between stressed banks and impaired firms persists even after forbearance is withdrawn.

The findings take on particular significance in the context of the ongoing COVID-19 crisis. In the wake of the pandemic, countries across the world have announced forbearance measures to help distressed firms tide over temporary liquidity shocks (Baudino, 2020). This paper provides a cautionary tale that, if not designed properly, temporary forbearance measures may be difficult to unwind and can have persistent effects on industry structure. As economies recover and forbearance policies are withdrawn, active regulatory intervention may be needed to correct for the prevalence of zombie lending (Kulkarni et al., 2020; Bonfim et al., 2020). While insufficient recapitalization can perversely increase zombie lending, a perverse match between stressed banks and zombie firms may impact the effectiveness of future policy interventions. 


\section{References}

Acharya, Viral. 2020. Quest for Restoring Financial Stability in India. Sage Publications Pvt. Limited.

Acharya, Viral V, Tim Eisert, Christian Eufinger, and Christian Hirsch. 2019. "Whatever it Takes: The Real Effects of Unconventional Monetary Policy." The Review of Financial Studies 32 (9), 3366-3411.

Acharya, Viral V, Irvind Gujral, Nirupama Kulkarni, and Hyun Song Shin. 2011. "Dividends and Bank Capital in the Financial Crisis of 2007-2009." Working Paper, New York University.

Agarwal, Sumit, David Lucca, Amit Seru, and Francesco Trebbi. 2014. "Inconsistent regulators: Evidence from banking". The Quarterly Journal of Economics 129 (2): 889938.

Akhigbe, Aigbe, and Ann Marie Whyte. 2001. "The Impact of FDICIA on Bank Returns and Risk: Evidence from the Capital Markets". Journal of Banking and Finance 25 (2): 393-417.

Andrews, Dan, and Filippos Petroulakis. 2019. "Breaking the Shackles: Zombie Firms, Weak Banks and Depressed Restructuring in Europe." ECB Working Paper No.2240.

Ansari, Jugnu, Khushboo Khandelwal, and Nagpurnanand Prabhala. 2016. "Financial Stress in Indian Corporates." Robert H. Smith School Research Paper No. RHS 2773398.

Baldursson, Fridrik M, and Richard Portes. 2013. "Gambling for Resurrection in Iceland: The Rise and Fall of the Banks." Working Paper, London Business School.

Banerjee, Ryan, and Boris Hofmann. 2018. "The Rise of Zombie Firms: Causes and Consequences." BIS Quarterly Review September.

Baudino, Patrizia. 2020. "Public Guarantees for Bank Lending in Response to the Covid-19 Pandemic", Bank for International Settlements Working Paper.

Ben-David, Itzhak, Ajay A Palvia, and René M Stulz. 2019. "Do Distressed Banks Really Gamble for Resurrection?", NBER Working Paper No. 25794.

Benston, George J., and George G. Kaufman. 1997. "FDICIA after Five Years". Journal of Economic Perspectives 11, No. 3 (September): 139-158. 
Blattner, Laura, Luisa Farinha, and Francisca Rebelo. 2019. "When Losses Turn into Loans: The Cost of Undercapitalized Banks.” ECB Working Paper No. 2228.

Bonfim, Diana, Geraldo Cerqueiro, Hans Degryse, and Steven Ongena. 2020. "On-Site Inspecting Zombie Lending." Swiss Finance Institute Research Paper No. 20-16.

Caballero, Ricardo J. 2007. Specificity and the Macroeconomics of Restructuring. Cambridge: The MIT Press.

Caballero, Ricardo J, Takeo Hoshi, and Anil K Kashyap. 2008. "Zombie Lending and Depressed Restructuring in Japan." American Economic Review, 98(5), 1943-77.

Chakrabarty, KC. 2013a. Infrastructure Financing by Banks in India-Myths and Realities, Keynote address at the Annual Infrastructure Finance Conclave organised by SBI Capital Markets Limited, Agra, 9.

- 2013b. Two Decades of Credit Management in Banks: Looking Back and Moving Ahead, RBI Bull, 67:17-40.

Chavan, Pallavi, and Leonardo Gambacorta. 2019. "Bank Lending and Loan Quality: An Emerging Economy Perspective". Empirical Economics 57 (1): 1-29.

Chopra, Yakshuo, Krishnamurthi Subrahmanian, and Prassana Tantri. 2020. "Bank Cleanups, Capitalization, and Lending: Evidence from India." Review of Financial Studies Forthcoming.

Cong, Lin William, Haoyu Gao, Jacopo Ponticelli, and Xiaoguang Yang. 2019. "Credit Allocation Under Economic Stimulus: Evidence From China." Review of Financial Studies 32 (9), 3412-3460.

Dewatripont, M., and E. Maskin. 1995. "Credit and Efficiency in Centralized and Decentralized Economies." The Review of Economic Studies 62 (4), 541-555.

Financial Stability Report (Including Trend and Progress of Banking in India 2013-14). 2014, Issue No. 10, Reserve Bank of India.

Flanagan, Thomas, and Amiyatosh Purnanandam. 2020. "Why Do Banks Hide Losses?", University of Michigan Working Paper.

Freixas, Xavier, Jean-Charles Rochet, and Bruno M. Parigi. 2010. "The Lender of Last Resort: A Twenty-First Century Approach." Journal of the European Economic Association 2 (6): 1085-1115. 
Gopinath, Gita, Sebnem Kalemli-Ozcan, Loukas Karabarbounis, and Carolina Villegas-Sanchez. 2017. "Capital Allocation and Productivity in South Europe." The Quarterly Journal of Economics 132, no. 4 (June): 1915-1967.

Gropp, Reint, Steven R. G. Ongena, Joerg Rocholl, and Vahid Saadi. 2020. "The Cleansing Effect of Banking Crises." CEPR Discussion Paper No. DP15025.

The Indian Express. 2018. Raghuram Rajan Explains: Understanding Bad Loans.

Khwaja, Asim Ijaz, and Atif Mian. 2005. "Do Lenders Favor Politically Connected Firms? Rent Provision in an Emerging Financial Market". The Quarterly Journal of Economics 120 (4): 1371-1411.

Koudstaal, Martin, and Sweder Van Wijnbergen. 2012. "On Risk, Leverage and Banks: Do Highly Leveraged Banks Take on Excessive Risk?" Working Paper, Tinbergen Institute.

Kulkarni, N., S. K. Ritadhi, S. Vij, and K. Waldock. 2020. "Unearthing Zombies", CAFRAL Working Paper.

Laeven, Luc, and Ross Levine. 2009. "Bank Governance, Regulation and Risk-Taking". Journal of Financial Economics 93 (2): 259-275.

Laeven, Luc, and Fabian Valencia. 2018. "Systemic Banking Crises Revisited." International Monetary Fund Working Paper No. 18/206.

McGowan, Adalet, Dan Andrews, and Valentine Millot. 2018. "The Walking Dead? Zombie Firms and Productivity Performance in OECD Countries." Economic Policy 33 (96), $685-736$.

Ministry of Labour and Employment. 2000. "Informal Sector in India: Approaches for Social Security". New Delhi: Government of India, Statement on Industrial Policy.

Faculty of Law, University of Oxford. 2016. Promoter Exits in India: A Real Leash Reined by the Market Watchdog?

Patel, Urjit. 2020. Overdraft: Saving the Indian Saver. Harper India.

Peek, J., and E. Rosengren. 2005. "Unnatural Selection: Perverse Incentives and the Misallocation of Credit in Japan." American Economic Review 95(4), 1144-1166.

Master Circular - Prudential Norms on Income Recognition, Asset Classification and Provisioning Pertaining to Advances. 2009, Reserve Bank of India. 
Master Circular - Prudential Norms on Income Recognition, Asset Classification and Provisioning Pertaining to Advances. 2015, Reserve Bank of India.

Annex 4: Prompt Corrective Action (PCA) Framework. 2014, Reserve Bank of India.

Insolvency and Bankruptcy Code and Bank Recapitalisation. 2017, Reserve Bank of India.

Report of the High Level Task Force on Public Credit Registry for India. 2008, Reserve Bank of India.

Storz, Manuela, Michael Koetter, Ralph Setzer, and Andreas Westphal. 2017. "Do We Want These Two to Tango? On Zombie Firms and Stressed Banks in Europe." IWH Discussion Papers 13/2017, Halle Institute for Economic Research (IWH).

Vishwanathan, NS. 2018. It is not Business as Usual for Lenders and Borrowers. Deputy Governor, Reserve Bank of India, Speech Delivered at National Institute of Bank Management, Pune on Fourteenth Convocation. 


\section{A Data Appendix}

Table A1: Major Regulatory Announcements since 2008

\begin{tabular}{l|l|l}
\hline Date & Content of Announcement & Direction of RF \\
\hline 27-Aug-08 & Special Regulatory Treatment Announced allowing forbearance & Increase \\
\hline 30-May-13 & Announcement of withdrawal of Forbearance beginning April 1, 2015 & Decrease \\
\hline 26-Feb-14 & $\begin{array}{l}\text { Framework for Revitalising Distressed Assets in the Economy-Guidelines } \\
\text { on Joint Lenders Forum (JLF) and Corrective Action Plan (CAP) }\end{array}$ & Increase \\
\hline 15-Jul-14 & $\begin{array}{l}\text { Flexible Structuring of Long Term Project Loans } \\
\text { to Infrastructure and Core Industries }\end{array}$ & Increase \\
\hline 1-Apr-15 & Asset Quality Review Started & Decrease \\
\hline 8-Jun-15 & Strategic Debt Restructuring Scheme for conversion of debt to equity & Increase \\
\hline 13-Jun-16 & Scheme for Sustainable Structuring of Stressed Assets & Increase \\
\hline 12-Feb-18 & Resolution of stressed assets: Revised Framework & Decrease
\end{tabular}

Notes: This table lists in a chronological order the major policy announcements by RBI pertaining to the increase or decrease in Regulatory Forbearance (RF) allowed on classification norms of stressed assets held by banks. The dates were collected by a detailed survey of all master RBI circulars released between August 27, 2008 and February 12, 2018. 
Table A2: Variables Description and Source

\begin{tabular}{|c|c|c|}
\hline \multicolumn{2}{|r|}{ Firm-level variables: } & \\
\hline $\log _{\text {Debt }_{j, t}}$ & Log of total borrowings of a firm in a year (million INR) & CMIE \\
\hline Capex $_{j, t}$ & $\begin{array}{l}\text { Total investment of a firm in a year measured as year-on-year change } \\
\text { in gross fixed capital formation as a fraction of lagged assets (million INR) }\end{array}$ & CMIE \\
\hline Wages Ratio & Total salaries paid in year as a fraction of total expenses (million INR) & CMIE \\
\hline New Relationship $_{j, t}$ & Dummy variable that equals one if firm forms a new banking/non-banking relationship & CMIE \\
\hline Low Solvency $_{j, t}$ & $\begin{array}{l}\text { Dummy variable that equals one if firm has a above median debt to equity ratio in the } \\
\text { cross-section of a year }\end{array}$ & CMIE \\
\hline Low Liquidity $_{j, t}$ & $\begin{array}{l}\text { Dummy variable that equals one if firm has a below median cash to current liabilities ratio } \\
\text { in the cross-section of a year }\end{array}$ & CMIE \\
\hline Zombie $_{j, t}$ (status 1) & $\begin{array}{l}\text { Dummy variable that equals one if a firm's average interest expenses (interest expenses scaled by debt) } \\
\text { are below the prime lending rate of State Bank of India \& debt to asset ratio greater than } 0.15\end{array}$ & CMIE \\
\hline Zombie $_{j, t}$ (status 2) & $\begin{array}{l}\text { Dummy variable that equals one if a firm is classified zombie as measured by the subsidised credit definition } \\
\text { and also has an interest coverage ratio below } 2\end{array}$ & CMIE \\
\hline Zombie $_{j, t}$ (status 3) & $\begin{array}{l}\text { Dummy variable that equals one if a firm satisfies the IMF's condition of speculative credit i.e. } \\
\text { net debt to assets ratio greater than } 0.25 \text { \& interest coverage ratio below } 4.1\end{array}$ & CMIE \\
\hline NonZombie $_{t}$ & $\begin{array}{l}\text { Dummy variable that equals one if a firm is not classified a zombie in a year measured by the above } \\
\text { zombie definitions }\end{array}$ & CMIE \\
\hline $\log _{\text {Sales }_{j, t}}$ & Log of total sales of a firm in a year (million INR) & CMIE \\
\hline Bond $_{j, t}$ & Dummy variable that equals one if a firm accessed bond market in a year & CMIE \\
\hline Industry Frac Zombie ${ }_{h, t}$ & $\begin{array}{l}\text { The fraction of total firms classified as a zombie in an industry in a year } \\
\text { Bank-level variables }\end{array}$ & CMIE \\
\hline Stressed Bank $b$ & $\begin{array}{l}\text { Dummy variable that equals one if a bank belonged to top two terciles of non-performing loans ratio in } \\
\text { the cross-section of year } 2007 \text { i.e. before announcement of forbearance policy }\end{array}$ & DBIE \\
\hline Public Bank $_{b}$ & Dummy variable that equals one if a bank has a majority ownership by government of India & DBIE \\
\hline CRAR Bank $_{b, t}$ & Bank's capital to risk weighted assets ratio (in \%) & DBIE \\
\hline Regulator Proximity $_{b}$ & $\begin{array}{l}\text { Dummy variable that equals one if the distance of the bank headquarters is below median } \\
\text { value in the cross-section of banks }\end{array}$ & CMIE \\
\hline Bank Frac Zombie $_{h, t}$ & $\begin{array}{l}\text { The fraction of total firms classified as a zombie in a bank's portfolio of total number of firms in a year } \\
\text { Year-level variables: }\end{array}$ & CMIE \\
\hline Forbearance $_{t}^{\text {Post } 2008}$ & $\begin{array}{l}\text { Dummy variable that equals one if year is after August } 2008 \text { i.e. when the special regulatory treatment/ } \\
\text { forbearance was introduced in aftermath of the GFC }\end{array}$ & $\mathrm{RBI}$ \\
\hline Forbearance $_{t}^{\text {Post } 2013}$ & Dummy variable that equals one if the year is after May 2013 i.e. after forbearance withdrawal was announced & RBI \\
\hline Prov rate $_{t}$ & The provisioning rate required by Reserve Bank of India on restructured loans in a year & $\mathrm{RBI}$ \\
\hline
\end{tabular}


Table A3: Sample Construction

A. CMIE-DBIE Matched Sample Construction and Coverage Summary: 2006-2016

\begin{tabular}{lcc}
\hline Variables & \# Observations & \# Unique Firms \\
\hline Number of non-financial firm-year observations in CMIE sample with non-missing assets & 206,999 & 35,275 \\
Number of firm-lead bank-year observations in CMIE banker's data & 60,955 & 44,198 \\
Number of firm-year observations matched to a lead banker & 38,016 & 9,020 \\
Number of firm-bank-year observations matched to DBIE bank-level data & 25,844 \\
Number of firm-bank-year observations with non-missing debt & 33,713 \\
Number of firm-bank-year observations with non-missing solvency status & 37,187 \\
Number of firm-bank-year observations with non-missing liquidity status & 38,016 \\
Number of firm-bank-year observations with non-missing zombie status 1 & 28,599 \\
Number of firm-bank-year observations with non-missing zombie status 2 & 27,342 \\
Number of firm-bank-year observations with non-missing zombie status 3 & 8,791 \\
\hline
\end{tabular}

B. DBIE Sample Coverage: 2006-2016

\begin{tabular}{lcc}
\hline Variables & \# Observations & \# Unique Banks \\
\hline Number of bank-year observations (only domestic Scheduled Commercial Banks) & 509 & 52 \\
Number of bank-year observations: public banks & 294 & 28 \\
Number of bank-year observations: private banks & 215 & 24 \\
Number of stressed banks: public banks & 187 & 17 \\
Number of stressed banks: private banks & 148 & 17 \\
\hline
\end{tabular}

Notes: This table reports the sample summary for the data sets for the period 2006-2016. Panel A ${ }^{36}$ reports the CMIE prowess data set's coverage summary at the firm-year and firm-lead bank-year level. The table also reports the reduction in number of observations as bank-level variables are merged. We also list the number of observations with non-missing values of various measures of firm quality as well as our main dependent variable, debt (in year $t+1$ ). Panel B 37 describes the Reserve Bank of India's DBIE dataset coverage at the bank-year level. A firm is classified as Zombie (status 1) if the the firm received subsidized credit in time period $\mathrm{T}$ i.e. the firm is able to borrow loans at an average interest rate that is lower than the Prime Lending Rate (PLR) of State Bank of India and has Debt to Assets ratio >.15. A firm is classified as Zombie (staus 2) if in addition to satisfying zombie status 1 , the firm has an ICR below 2 . A firm is classified as Zombie (status 3 ) if the the firm satisfies the IMF's definition of speculative credit i.e. has an ICR less than 4.1 and a net debt-to-assets ratio greater than 0.25 . Net debt is gross debt minus cash.

${ }^{36}$ For the baseline definition of zombie (zombie status 1 ), we take a conservative approach and classify firms with missing average interest rate as 'healthy'. We relax this assumption in the alternative zombie definition (zombie status 2), where we only consider non-missing values of average interest rate.

${ }^{37}$ The banks that were merged during our sample are dropped when matching bank-level data to firm-level data resulting in a match of 39 banks of which 29 are classified as stressed. The number of stressed public banks is 16 \& the number of stressed private banks is 13 . 
Figure 1: The Time-series Evolution of Troubled Asset Ratios

Notes: This figure plots the time-series evolution of annual troubled asset ratios for the period 2005-2016 for public and private sector banks. Panel A of the figure plots the evolution of average bank level proportion of restructured loans in the total distressed loans during the sample period 2006-2016. Panel B of the figure shows the evolution of average bank level proportion of non-performing loans in the total loans during the sample period 2006-2016. Panel C of the figure shows the evolution of average bank level proportion of distressed loans in the total loans given out by a bank during the sample period 2006-2016. The 'Hidden Assets Ratio' is computed as the restructured assets as a proportion of restructured and non-performing assets on a bank's balance sheet $\left(\frac{R A}{D A}\right)$. Distressed Assets are defined as the sum of non-performing loans (NPAs) and restructured loans (RA) in any given year. The NPA ratio as the ratio of non-performing assets to gross advances $\left(\frac{N P A}{G A}\right)$. The distressed assets ratio is the fraction of restructured assets and non-performing assets as a proportion of gross advances by bank $\left(\frac{D A}{G A}\right)$. Public banks are banks with majority ownership of the government of India. Public and private sector bank classification is from DBIE.

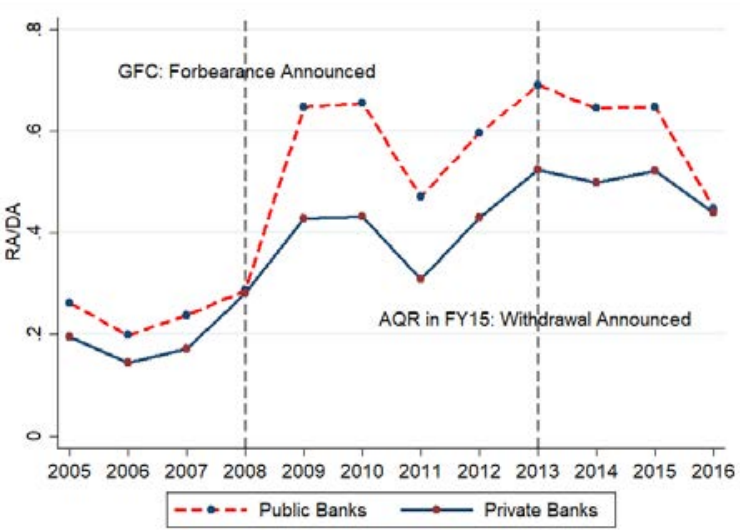

(a) Hidden Assets Ratio $\left(\frac{R A}{D A}\right)$

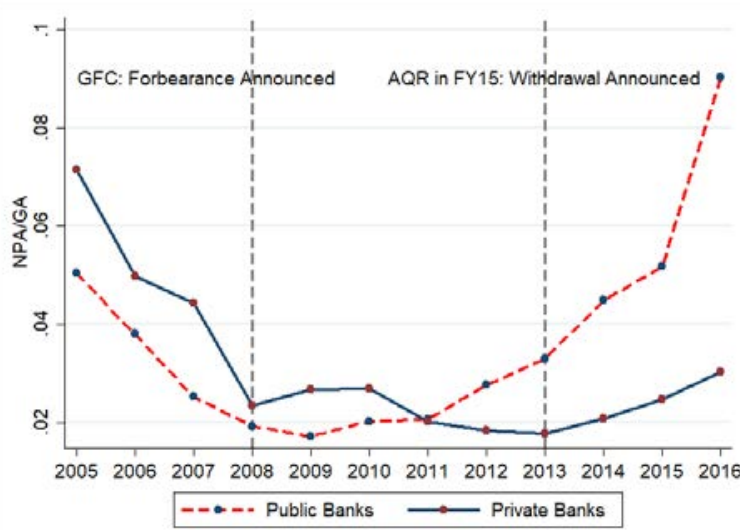

(b) Non-performing Assets Ratio $\left(\frac{N P A}{G A}\right)$

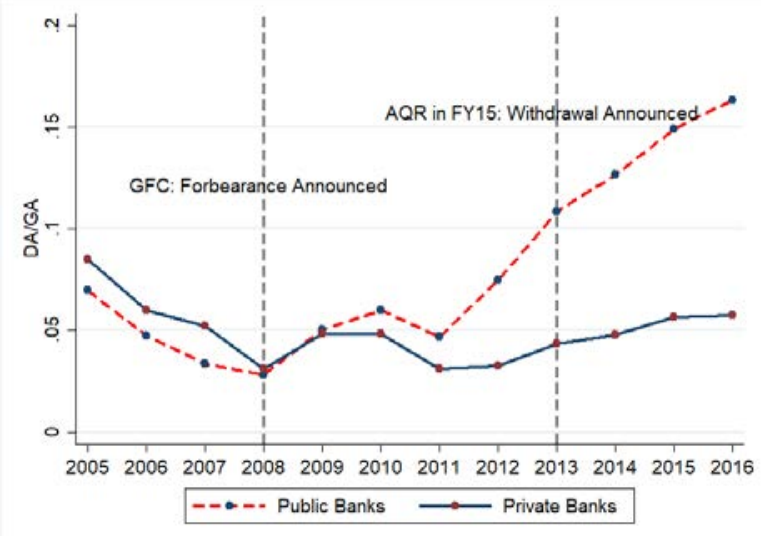

(c) Distressed Assets Ratio $\left(\frac{D A}{G A}\right)$ 
Figure 2: Firm Borrowing Based on Solvency, Liquidity and Zombie Status

Notes: Panel A of the figure shows the evolution of sum of loans issued by stressed banks and good banks during the sample period 2006-2016. A bank is classified as Stressed Bank if the proportion of non-performing loans in the total gross advances (loans) for the bank is in top two terciles in 2007 i.e. the year before the introduction of the forbearance policy by RBI. The remaining one-third of the banks are classified as good banks. Panel B of the figure shows the log-ratio of total debt borrowed by zombie and no-zombie firms in a given year relative to the year of the forbearance announcement, i.e., the y-axis is normalized to 0 at the announcement year in 2008. A firm is classified as Zombie if the the firm received subsidized credit in time period $T$ i.e. the firm is able to borrow loans at an average interest rate that is lower than the Prime Lending Rate (PLR) of State Bank of India and has Debt to Assets ratio $>.15$. Remaining firms are classified as nonzombies. Panel $\mathrm{C}$ of the figure shows the log-ratio of total debt borrowed by the low-solvency and solvent firms in a given year relative to the year of the forbearance announcement, i.e., the y-axis is normalized to 0 at the year of the announcement in 2008. A firm is classified as Low Solvency if the Debt to equity measure of the firm in time period $T$ is above median. Remaining firms are classified as solvent. Panel D of the figure shows the log-ratio of total debt borrowed by the low-liquidity and liquid firms in a given year relative to the year of the forbearance announcement, i.e., the y-axis is normalized to 0 at the year of the announcement in 2008. A firm is classified as Low Liquidity if the cash ratio measure of the firm in time period $T$ is below median. Remaining firms are classified as liquid.

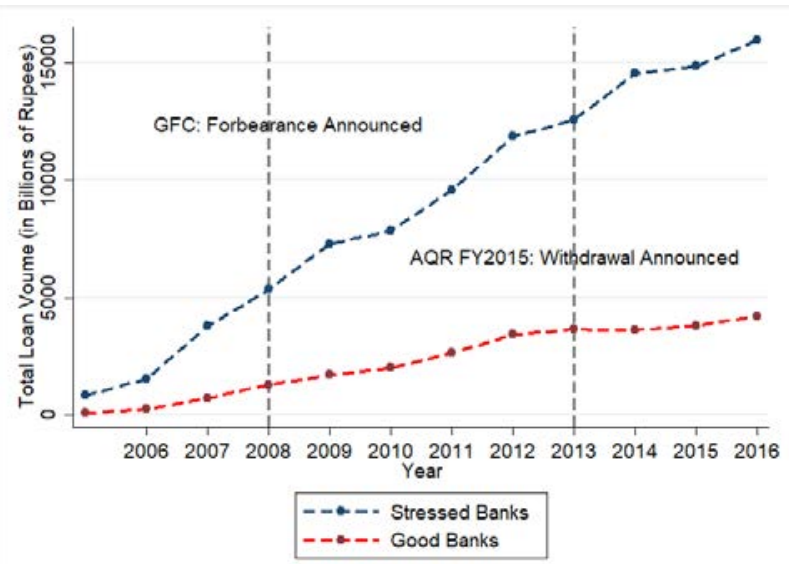

(a) Aggregate Lending By Banks

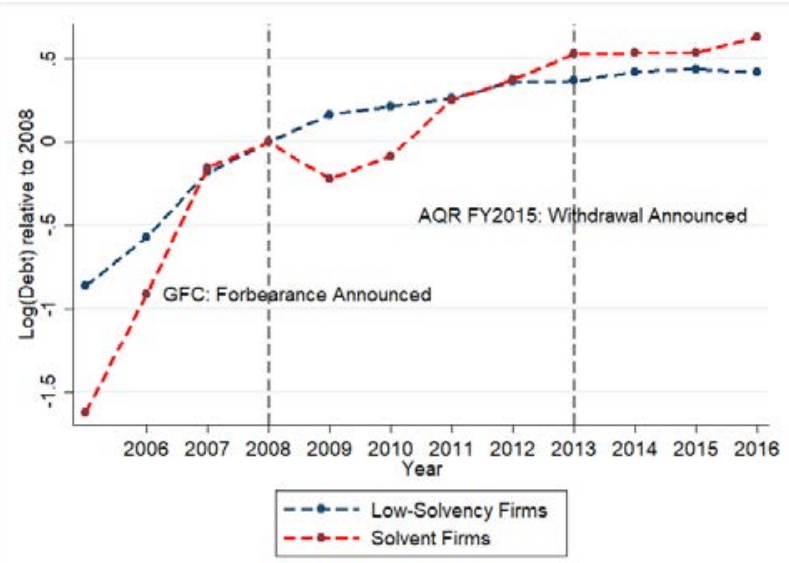

(c) Debt of Low-solvency \& Solvent firms ${ }_{51}$ (d) Debt of Low-liquidity \& Liquid firms

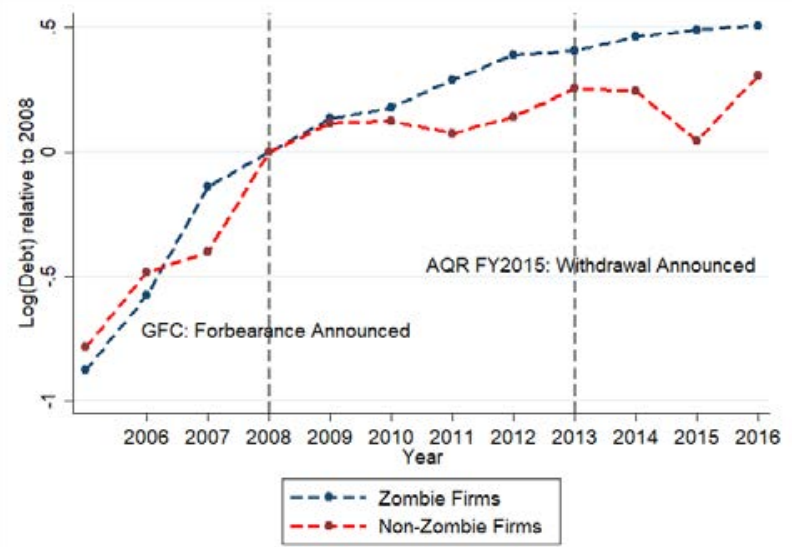

(b) Debt of Zombie \& Non-zombie Firms

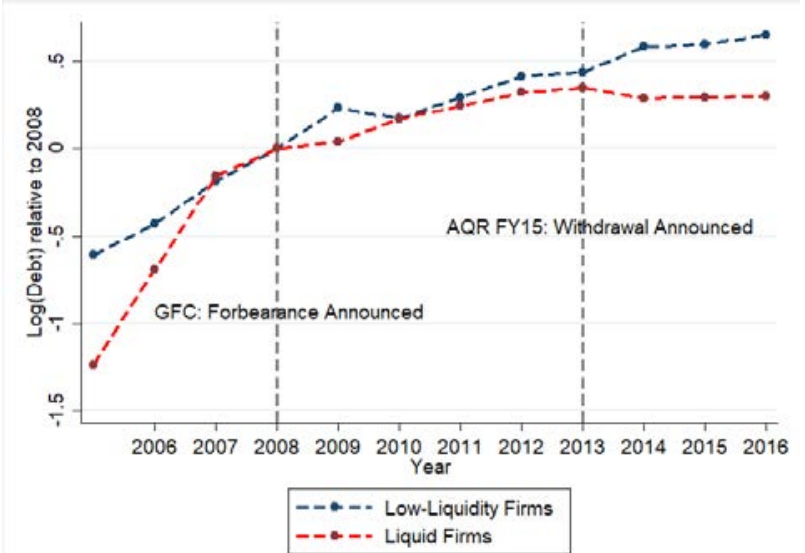


Figure 3: Event Study: The Impact of Forbearance on Lending to Zombie Borrowers

Notes: This figure shows the event study plots for the impact of forbearance policy on zombie lending using the Equation 3 with an indicator for each year. The coefficient for the triple interaction term with Stressed Bank ${ }_{b}, Z_{o m b i e}, t$, and an indicator for each year is plotted below. The gray bars represent the 5 percent confidence interval. The dependent variable is the firm-level log of debt in period $\mathrm{T}+1$. A bank is classified as Stressed Bank if the proportion of non-performing loans in the total gross advances (loans) for a bank is in the top two terciles in year 2007 i.e. before the introduction of the forbearance policy by RBI. A firm is classified as Zombie if the firm received subsidized credit in time period T i.e. the firm can borrow loans at an average interest rate that is lower than the Prime Lending Rate (PLR) of State Bank of India and has a debt to assets ratio $>$.15. The specification controls for the year fixed effects, time-invariant bank fixed effects, timeinvariant borrower characteristics and time-varying firm size via log of sales. Standard errors are clustered at firm level. 95\% confidence intervals are shown.

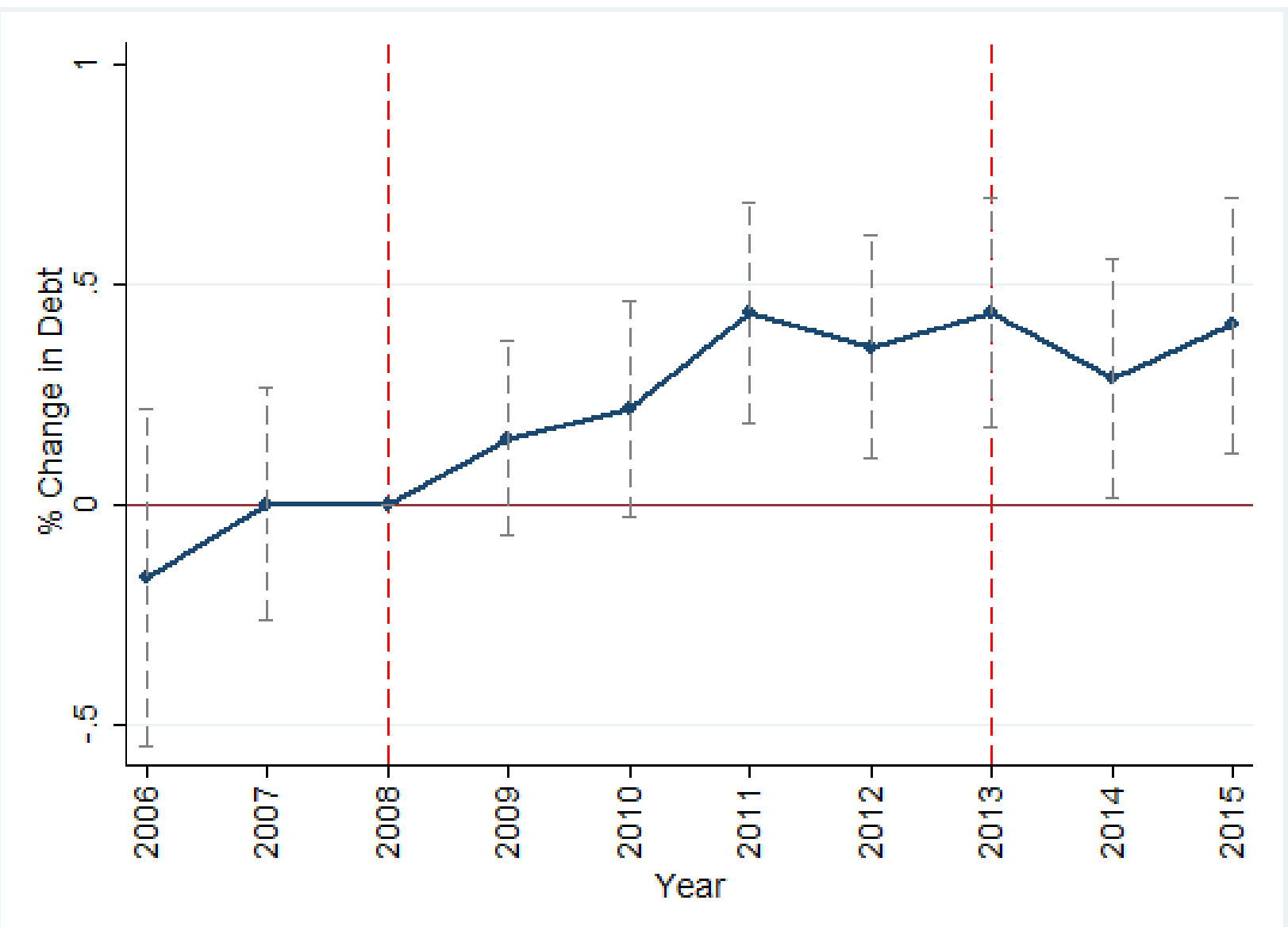


Figure 4: Public and Private Sector Banks: Distressed Asset Share to Market Share

Notes: Figure 4 plots the time-series evolution of the bank-level average of ratio of distressed assets share and the market share for the period 2005-2016. The distressed assets share of a bank is defined as the sum of non-performing assets (NPAs) and restructured assets (RAs) out of gross advances (loans) in a given year. The market share is defined as the proportion of a bank's loans in the total loans of the aggregate banking sector in a year. Public banks are banks with majority ownership of the government of India. Public and private sector bank classification is from DBIE.

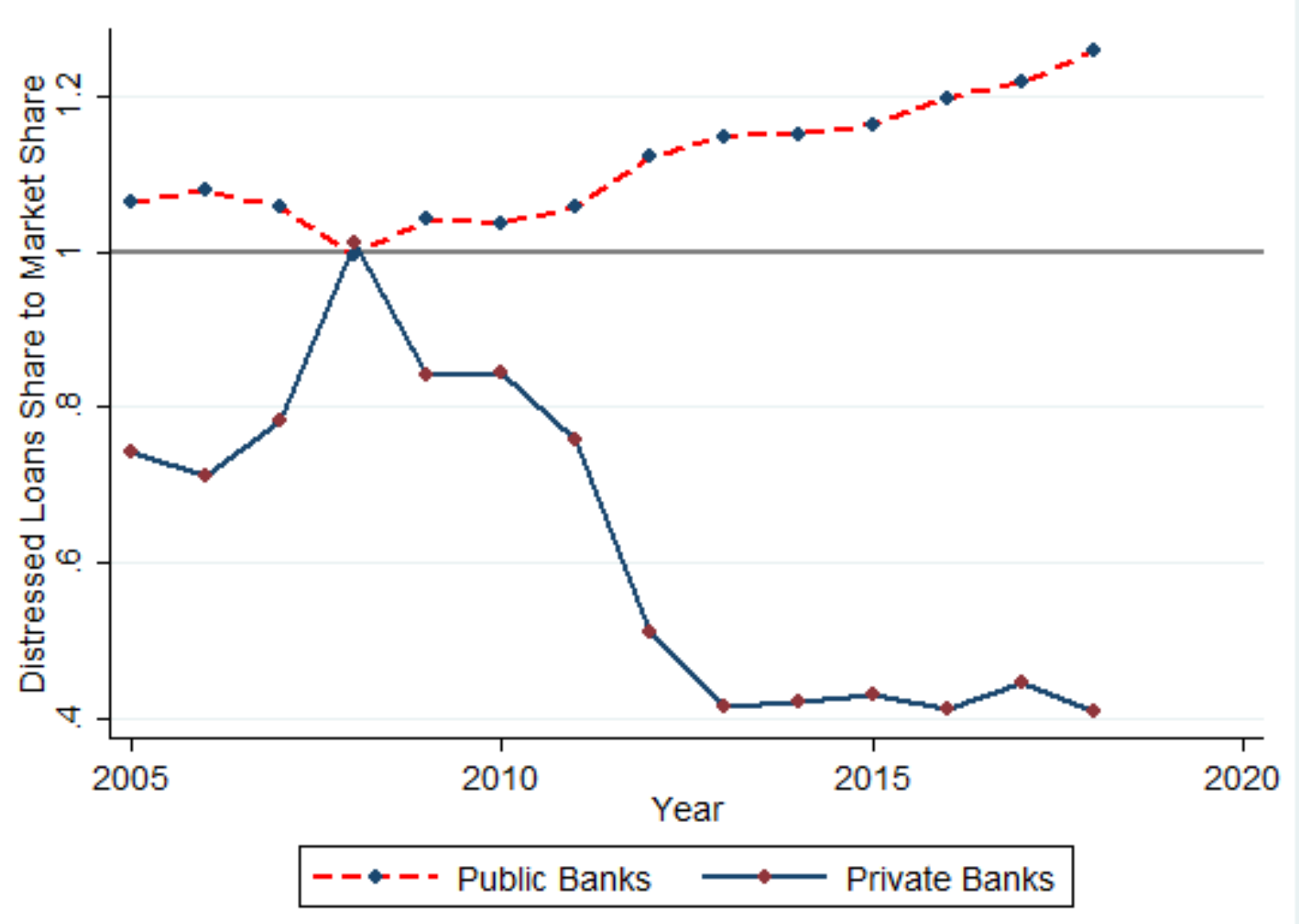


Table 1: Panel A: Firm-Year Univariate Tests by Solvency \& Liquidity Status

\begin{tabular}{|c|c|c|c|c|c|c|}
\hline \multirow[b]{2}{*}{ Variables } & \multicolumn{3}{|c|}{ Solvency Status } & \multicolumn{3}{|c|}{ Liquidity Status } \\
\hline & Solvent & Low-Solvency & Diff & Liquid & Low-Liquidity & Diff \\
\hline Cash Ratio & 1.62 & 0.28 & $(* * *)$ & 1.72 & 0.03 & $(* * *)$ \\
\hline Quick Ratio & 3.47 & 0.90 & $(* * *)$ & 3.39 & 0.67 & $(* * *)$ \\
\hline Debt Equity ratio & 0.16 & 4.91 & $(* * *)$ & 1.47 & 3.52 & $(* * *)$ \\
\hline Debt Assets Ratio & 0.12 & 0.45 & $(* * *)$ & 0.38 & 0.67 & $(* * *)$ \\
\hline Interest Coverage Ratio & 50.41 & 10.07 & $(* * *)$ & 40.65 & 18.41 & $(* * *)$ \\
\hline Log Sales & 4.10 & 6.47 & $(* * *)$ & 5.15 & 5.83 & $(* * *)$ \\
\hline Log Debt & 5.75 & 6.95 & $(* * *)$ & 6.10 & 6.38 & $(* * *)$ \\
\hline Capex Ratio & 0.04 & 0.06 & $(* * *)$ & 0.05 & 0.04 & $(* * *)$ \\
\hline Wages Ratio & 0.15 & 0.08 & $(* * *)$ & 0.13 & 0.09 & $(* * *)$ \\
\hline Avg Interest Rate & 37.98 & 10.76 & $(* * *)$ & 28.06 & 13.89 & $(* * *)$ \\
\hline Observations & 16,260 & 17,453 & & 17,715 & 19,472 & \\
\hline
\end{tabular}

Panel B: Firm-Year Univariate Tests by Zombie Status

\begin{tabular}{|c|c|c|c|c|c|c|c|c|c|}
\hline \multirow[b]{2}{*}{ Variables } & \multicolumn{3}{|c|}{ Zombie Status 1} & \multicolumn{3}{|c|}{ Zombie Status 2} & \multicolumn{3}{|c|}{ Zombie Status 3} \\
\hline & Healthy & Zombie & Diff & Healthy & Zombie & Diff & Healthy & Zombie & Diff \\
\hline Cash Ratio & 1.474 & 0.215 & $(* * *)$ & 0.402 & 0.215 & $(* * *)$ & 0.655 & 0.154 & $(* * *)$ \\
\hline Quick Ratio & 3.121 & 0.845 & $(* * *)$ & 1.180 & 0.866 & $(* * *)$ & 1.716 & 0.691 & $(* * *)$ \\
\hline Debt Equity ratio & 1.953 & 3.305 & $(* * *)$ & 1.352 & 5.344 & $(* * *)$ & 1.365 & 4.014 & $(* * *)$ \\
\hline Debt Assets Ratio & 0.511 & 0.582 & $(* * *)$ & 0.327 & 0.744 & $(* * *)$ & 0.295 & 0.586 & $(* * *)$ \\
\hline Interest Coverage Ratio & 55.710 & 4.823 & $(* * *)$ & 13.710 & 0.802 & $(* * *)$ & 32.476 & 1.593 & $(* * *)$ \\
\hline Log Sales & 4.154 & 6.500 & $(* * *)$ & 5.668 & 6.380 & $(* * *)$ & 5.001 & 6.748 & $(* * *)$ \\
\hline Log Debt & 5.436 & 6.894 & $(* * *)$ & 6.946 & 6.373 & $(* * *)$ & 6.518 & 7.052 & $(* * *)$ \\
\hline Capex Ratio & 0.037 & 0.053 & $(* * *)$ & 0.051 & 0.038 & $(* * *)$ & 0.049 & 0.046 & $(*)$ \\
\hline Wages Ratio & 0.159 & 0.075 & $(* * *)$ & 0.087 & 0.082 & $(* * *)$ & 0.107 & 0.067 & $(* * *)$ \\
\hline Avg Interest Rate & 43.224 & 7.764 & $(* * *)$ & 25.339 & 8.333 & $(* * *)$ & 30.003 & 11.375 & $(* * *)$ \\
\hline Observations & 19,177 & 18,839 & & 19,393 & 9,206 & & 13,971 & 13,371 & \\
\hline
\end{tabular}

Notes: Panels A and B show the summary statistics for the selected firm level ratios used in our analysis. We present the statistics for high and low quality borrowers by: Solvency, Liquidity and Zombie status. We also test for the significance of the difference in means between the high and low quality groups. A firm is classified as Low Solvency if the debt to equity measure of the firm in time period $\mathrm{T}$ is above median. A firm is classified as Low Liquidity if the cash ratio measure of the firm in time period $\mathrm{T}$ is below median. A firm is classified as Zombie (status 1 ) if the the firm received $>$. 15. A firm is classified as Zombie (staus 2) if in addition to satisfying zombie status 1, the firm has an ICR below 2. A firm is classified as Zombie (status 3 ) if the the firm satisfies the IMF's definition of speculative credit i.e. has an ICR less than 4.1 and a net debt-to-assets ratio greater than 0.25 . Net debt is gross debt minus cash. Capex and wages ratio are capital expenditure and wage bill respectively scaled by total expenses in a year. 
Panel C: Bank-Year Univariate Tests by Health Status

\begin{tabular}{|c|c|c|c|}
\hline \multirow[b]{2}{*}{ Variables } & \multicolumn{2}{|c|}{ Bank Health Status } & \multirow{2}{*}{$\frac{\text { t-test }}{\text { Diff }}$} \\
\hline & Healthy Banks & Stressed Banks & \\
\hline Log Gross Advances & 13.140 & 12.810 & $(* *)$ \\
\hline Log Assets & 13.672 & 13.300 & $(* * *)$ \\
\hline Restructured Assets Ratio & 0.031 & 0.035 & \\
\hline Non-Performing Loans Ratio & 0.024 & 0.036 & $(* * *)$ \\
\hline Distressed Assets Ratio & 0.055 & 0.071 & $(* * *)$ \\
\hline Observations & 174 & 335 & \\
\hline
\end{tabular}

Notes: Panel C summarizes the main variables used in analysis from the bank-year data set obtained from Reserve Bank of India (DBIE website) for the sample period 2006-2016. The variables, Gross Advances, assets and stressed assets are originally measured in million INR. Stressed assets are sum of non-performing loans and restructured loans in a year. All the ratio variables are calculated as proportions out of the gross advances. 
Table 2: The Relationship Between Bank and Firm Distress

\begin{tabular}{llll}
\hline Measure & $\frac{R A}{D A}$ & $\frac{N P A}{G A}$ & $\frac{D A}{G A}$ \\
\hline \% Borrowers (Debt-Equity Ratio $>$ Q4) & $0.722^{* * *}$ & $0.0362^{* * *}$ & $0.144^{* * *}$ \\
\% Borrowers (Debt-Equity Ratio > Q2) & $0.695^{* * *}$ & -0.00164 & $0.0769^{* * *}$ \\
\% Borrowers (Debt-Equity Ratio $>2$ ) & $1.303^{* * *}$ & $0.0408^{* * *}$ & $0.212^{* * *}$ \\
\% Borrowers (Cash Ratio $<$ Q1) & $0.384^{* *}$ & $0.0310^{*}$ & $0.0946^{* * *}$ \\
\% Borrowers (Cash Ratio $<\mathrm{Q} 2)$ & $0.387^{* * *}$ & 0.00935 & $0.0407^{*}$ \\
\% Borrowers (Cash Ratio $<1$ ) & $0.973^{* * *}$ & $0.0776^{* * *}$ & $0.219^{* * *}$ \\
\hline
\end{tabular}

Notes: This table summarizes the correlation between bank level ratios and the proportion of low quality borrowers in the bank's portfolio i.e. proportion of firms with low solvency measures and low liquidity measures in a bank's portfolio. RA/DA is restructured assets as a proportion of restructured and non-performing assets on a bank's balance sheet. NPA/GA is the ratio of non-performing assets to gross advances. DA/GA is the fraction of restructured assets and non-performing assets as a proportion of gross advances by the bank. Debt-Equity Ratio is used as a measure of solvency and Cash Ratio (Cash to Current Liabilities) is used as a measure of liquidity. Cash ratio $<Q 1$ refers to the proportion of borrowers with a cash ratio measure in the lowest quartile Q1. Cash ratio $<Q 2$ refers to the proportion of borrowers with a cash ratio measure below the median Q2. Cash ratio $<1$ refers to the proportion of borrowers with a cash ratio measure $<1$ which is the industry accepted signal of declining liquidity. Debt-Equity Ratio $>$ Q4 refers to the proportion of borrowers with a debt to equity measure in the top quartile Q4. Debt-Equity Ratio $>Q 2$ refers to the proportion of borrowers with a debt to equity measure above the median Q2. Debt-Equity Ratio $>2$ refers to the proportion of borrowers with a debt to equity measure $>2$ which is the industry accepted signal of insolvency. All measures are computed separately for each year. 
Table 3: Confusion Matrices for the Panel of Firm-Year-Bank Observations in the Sample

\begin{tabular}{|c|c|c|c|c|c|c|c|c|}
\hline & \multicolumn{4}{|c|}{ Healthy Banks } & \multicolumn{4}{|c|}{ Stressed Banks } \\
\hline Solvency $_{j, t}$ & $\begin{array}{l}\text { High } \\
\text { Low } \\
\text { Overall }\end{array}$ & $\begin{array}{l}\text { High } \\
38 \% \\
18 \% \\
56 \%\end{array}$ & $\begin{array}{r}\text { iquid } \\
\text { Low } \\
16 \% \\
28 \% \\
44 \%\end{array}$ & $\begin{array}{l}\mathrm{y}_{j, t} \\
\text { Overall } \\
54 \% \\
46 \% \\
100 \%\end{array}$ & $\begin{array}{l}\text { High } \\
\text { Low } \\
\text { Overall }\end{array}$ & $\begin{array}{l}\text { High } \\
30 \% \\
18 \% \\
48 \%\end{array}$ & $\begin{array}{l}\text { iquidi } \\
\text { Low } \\
14 \% \\
38 \% \\
52 \%\end{array}$ & $\begin{array}{l}\mathrm{y}_{j, t} \\
\text { Overall } \\
44 \% \\
56 \% \\
100 \%\end{array}$ \\
\hline Solvency $_{j, t}$ & $\begin{array}{l}\text { High } \\
\text { Low } \\
\text { Overall }\end{array}$ & $\begin{array}{l}\text { No } \\
47 \% \\
12 \% \\
58 \%\end{array}$ & $\begin{array}{c}\text { Zomb } \\
\text { Yes } \\
8 \% \\
33 \% \\
42 \%\end{array}$ & $\begin{array}{l}j, t \\
\text { Overall } \\
55 \% \\
45 \% \\
100 \%\end{array}$ & $\begin{array}{l}\text { High } \\
\text { Low } \\
\text { Overall }\end{array}$ & $\begin{array}{l}\text { No } \\
35 \% \\
12 \% \\
47 \%\end{array}$ & $\begin{array}{l}\text { Zomb } \\
\text { Yes } \\
9 \% \\
44 \% \\
53 \%\end{array}$ & $\begin{array}{l}j, t \\
\text { Overall } \\
45 \% \\
55 \% \\
100 \%\end{array}$ \\
\hline Liquidity $_{j, t}$ & $\begin{array}{l}\text { High } \\
\text { Low } \\
\text { Overall }\end{array}$ & $\begin{array}{l}\text { No } \\
36 \% \\
21 \% \\
56 \%\end{array}$ & $\begin{array}{c}\text { Zomb } \\
\text { Yes } \\
17 \% \\
27 \% \\
44 \%\end{array}$ & $\begin{array}{l}j, t \\
\text { Overall } \\
53 \% \\
47 \% \\
100 \%\end{array}$ & $\begin{array}{l}\text { High } \\
\text { Low } \\
\text { Overall }\end{array}$ & $\begin{array}{l}\text { No } \\
27 \% \\
19 \% \\
46 \%\end{array}$ & $\begin{array}{l}\text { Zomb } \\
\text { Yes } \\
19 \% \\
36 \% \\
54 \%\end{array}$ & $\begin{array}{l}j, t \\
\text { Overall } \\
45 \% \\
55 \% \\
100 \%\end{array}$ \\
\hline
\end{tabular}

The total number of firm-year observations in the full sample are 38,016 .

Notes: This table shows the distribution of the sample across the measures of firm quality and bank quality. A bank is classified as Stressed Bank if the proportion of non-performing loans in the total gross advances (loans) for a bank is in the top two terciles in 2007 i.e. before the introduction of forbearance policy by RBI. A firm is classified as Low Solvency if the Debt to equity measure of the firm in time period $\mathrm{T}$ is above median. A firm is classified as Low Liquidity if the cash ratio measure of the firm in time period $\mathrm{T}$ is below median. A firm is classified as Zombie if the the firm received subsidized credit in time period $\mathrm{T}$ i.e. the firm is able to borrow loans at an average interest rate that is lower than the Prime Lending Rate (PLR) of State Bank of India and has Debt to Assets ratio > .15. 
Table 4: The Impact of Forbearance on Debt of Low-solvency and Low-liquidity Firms

\begin{tabular}{|c|c|c|c|c|}
\hline \multirow[t]{2}{*}{ Dependent Variable: $\log$ Debt $_{j, t+1}$} & \multicolumn{2}{|c|}{ Solvency } & \multicolumn{2}{|c|}{ Liquidity } \\
\hline & (1) & $(2)$ & $(3)$ & $(4)$ \\
\hline Stressed Bank $_{b} *$ Low Solvency ${ }_{j, t} *$ Forbearance $_{t}^{\text {Post } 2008}$ & $\begin{array}{c}0.359^{* * *} \\
(0.125)\end{array}$ & $\begin{array}{c}0.384^{* * *} \\
(0.123)\end{array}$ & & \\
\hline Stressed Bank $_{b} *$ Low Solvency ${ }_{j, t} *$ Forbearance $_{t}^{\text {Post } 2013}$ & $\begin{array}{c}0.0661 \\
(0.0899)\end{array}$ & $\begin{array}{c}0.0603 \\
(0.0893)\end{array}$ & & \\
\hline Stressed Bank $_{b} *$ Low Liquidity ${ }_{j, t} *$ Forbearance $_{t}^{\text {Post } 2008}$ & & & $\begin{array}{l}0.310^{* * *} \\
(0.0939)\end{array}$ & $\begin{array}{l}0.306^{* * *} \\
(0.0928)\end{array}$ \\
\hline Stressed Bank $_{b} *$ Low Liquidity ${ }_{j, t} *$ Forbearance $_{t}^{\text {Post } 2013}$ & & & $\begin{array}{l}-0.0304 \\
(0.0884)\end{array}$ & $\begin{array}{l}-0.0182 \\
(0.0883)\end{array}$ \\
\hline No. of Observations & 21827 & 21827 & 24080 & 24080 \\
\hline $\mathrm{R}^{2}$ & 0.931 & 0.933 & 0.927 & 0.928 \\
\hline Borrower FE & $\mathrm{Y}$ & $\mathrm{Y}$ & $\mathrm{Y}$ & $\mathrm{Y}$ \\
\hline Year FE & $\mathrm{N}$ & Y & $\mathrm{N}$ & $\mathrm{Y}$ \\
\hline Bank FE & $\mathrm{N}$ & $\mathrm{Y}$ & $\mathrm{N}$ & $\mathrm{Y}$ \\
\hline
\end{tabular}

Standard errors in parentheses; ${ }^{*} p<0.10,{ }^{* *} p<0.05,{ }^{* * *} p<0.01$.

The total number of firm-year observations in the full sample are 38,016 .

Notes: This table shows the results for the impact on lending to low-solvency (columns 1-2) and low-liquidity (columns 3-4) firms at stressed banks using a triple difference specification. The dependent variable is the log of debt of a firm in period $\mathrm{T}+1$. A bank is classified as Stressed Bank if the proportion of non-performing loans in the total gross advances (loans) for the bank is in the top two terciles in 2007 i.e. before the introduction of forbearance policy by RBI. A firm is classified as Low Solvency if the debt to equity measure of the firm in time period $\mathrm{T}$ is above median. A firm is classified as Low Liquidity if the cash ratio measure of the firm in time period $\mathrm{T}$ is below median. The indicator variable Forbearance ${ }^{\text {Post } 2008}$ takes a value 1 in the years post 2008 i.e. after the introduction of forbearance. The indicator variable Forbearance ${ }^{\text {Post } 2013}$ takes a value 1 in the years post 2013 i.e. after the announcement of withdrawal of forbearance by RBI. Only the triple interaction terms are shown though remaining interaction terms, not absorbed by the fixed effects, are also included but not shown for brevity. Borrower, year, and bank fixed effects are as indicated. All specifications control for time-invariant borrower characteristics and time-varying firm size via log of sales. Standard errors are clustered at the firm level. 
Table 5: The Impact of Forbearance on Zombie and Healthy Firms

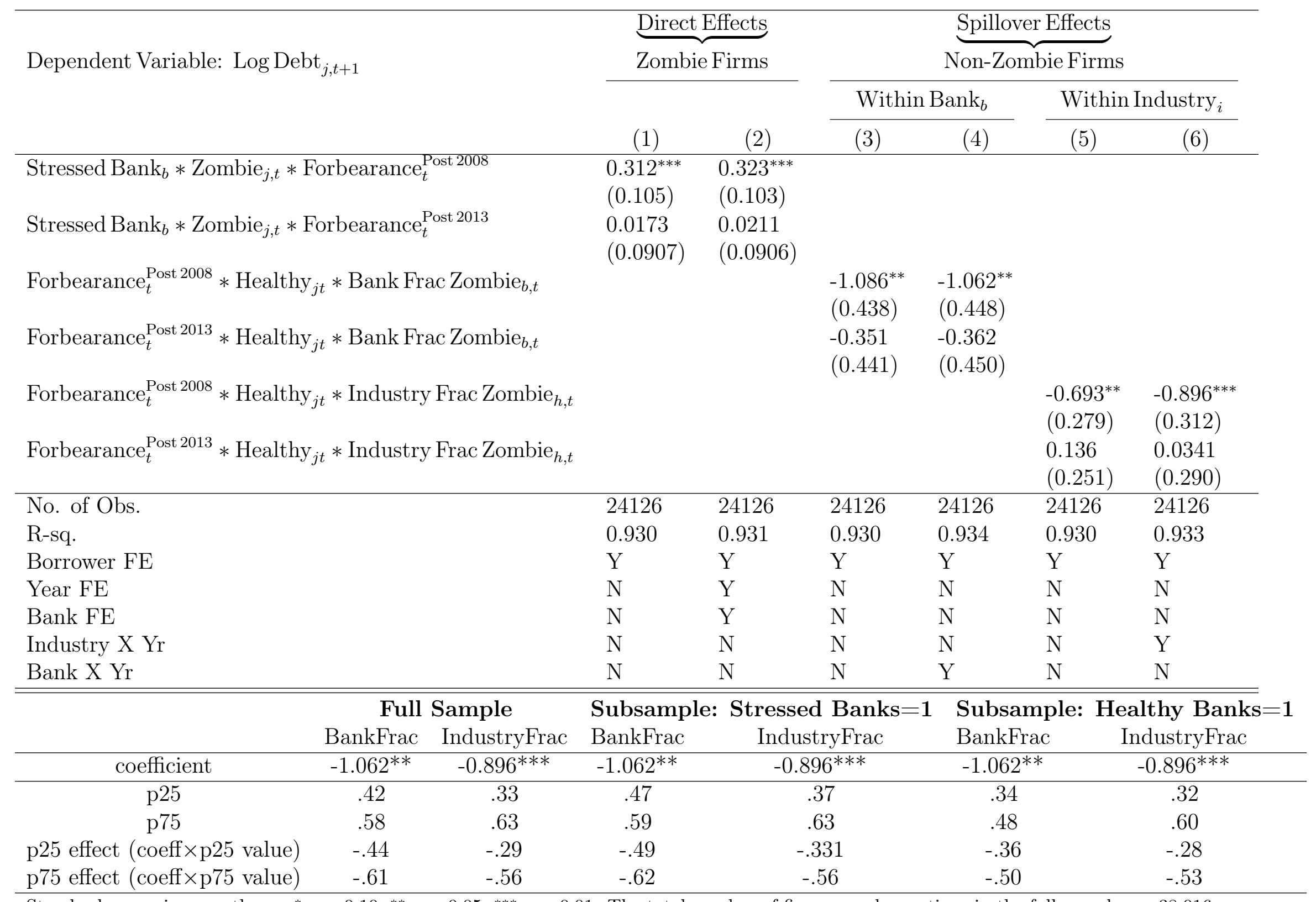

Standard errors in parentheses; ${ }^{*} p<0.10,{ }^{* *} p<0.05,{ }^{* * *} p<0.01$. The total number of firm-year observations in the full sample are 38,016 . 
Notes: This table summarizes the direct (columns 1-2) and spillover effects (columns 3-6) of regulatory forbearance on debt using a triple difference specification. The dependent variable in all columns is the firm-level log of debt in $\mathrm{T}+1$. A firm is classified as Zombie if the the firm received subsidized credit in time period $\mathrm{T}$ i.e. the firm is able to borrow loans at an average interest rate that is lower than the Prime Lending Rate (PLR) of State Bank of India and has Debt to Assets ratio > .15. A bank is classified as Stressed Bank if the proportion of non-performing loans in the total gross advances (loans) for the bank is in the top two terciles in 2007 i.e. before the introduction of Forbearance policy by RBI. The indicator variable Forbearance $\mathrm{P}^{\text {Post } 2008}$ takes a value 1 in the years Post 2008 i.e. after the introduction of Forbearance. The indicator variable Forbearance ${ }^{\text {Post } 2013}$ takes a value 1 in the years Post 2013 i.e. after the announcement of withdrawal of Forbearance by RBI. Industry Frac Zombie Z $_{h, t}$ is the fraction of total firms classified as a zombie in an industry in time period T. Bank Frac Zombie $b, t$ is the fraction of total firms classified as a zombie in a bank's portfolio in time period T. Only the triple interaction terms are shown though remaining interaction terms, not absorbed by the fixed effects, are also included but not shown for brevity. All specifications control for time-invariant borrower characteristics and time-varying firm size via log of sales. Borrower, year, industry-year and bank fixed effects are as indicated. Standard errors are clustered at firm level. 
Table 6: The Impact of Forbearance on Investment and Wages

\begin{tabular}{|c|c|c|c|c|}
\hline \multirow[t]{2}{*}{ Dependent Variable : } & \multicolumn{2}{|c|}{$\operatorname{Capex}_{j, t+1}=\frac{\Delta \operatorname{GFA}_{j, t+1}}{\text { Total Assets }_{j, t+1}}$} & \multicolumn{2}{|c|}{$\operatorname{Emp}_{j, t+1}=\frac{\text { Wages }_{j, t+1}}{\text { Total Expenses }}$} \\
\hline & (1) & $(2)$ & $(3)$ & (4) \\
\hline Stressed Bank $_{b} *$ Low Solvency ${ }_{j, t} * \mathrm{RF}_{t}^{\text {Post } 2008}$ & $\begin{array}{l}-0.0171^{*} \\
(0.00932)\end{array}$ & $\begin{array}{l}-0.0173^{*} \\
(0.00931)\end{array}$ & $\begin{array}{l}0.0163^{* *} \\
(0.00705)\end{array}$ & $\begin{array}{l}0.0162^{* *} \\
(0.00704)\end{array}$ \\
\hline Stressed Bank $_{b} *$ Low Solvency ${ }_{j, t} * \mathrm{RF}_{t}^{\text {Post } 2013}$ & $\begin{array}{l}0.00820 \\
(0.00619)\end{array}$ & $\begin{array}{c}0.00790 \\
(0.00620)\end{array}$ & $\begin{array}{l}-0.0116^{*} \\
(0.00666)\end{array}$ & $\begin{array}{l}-0.0111^{*} \\
(0.00667)\end{array}$ \\
\hline No. of Observations & 22144 & 22144 & 24678 & 24678 \\
\hline $\mathrm{R}^{2}$ & 0.453 & 0.456 & 0.862 & 0.863 \\
\hline
\end{tabular}

Panel B: Low-Liquidity Firms

\begin{tabular}{|c|c|c|c|c|}
\hline & $(5)$ & (6) & $(7)$ & $(8)$ \\
\hline Stressed Bank $_{b} *$ Low Liquidity ${ }_{j, t} * \mathrm{RF}_{t}^{\text {Post } 2008}$ & $\begin{array}{c}-0.0105 \\
(0.00804)\end{array}$ & $\begin{array}{c}-0.00973 \\
(0.00803)\end{array}$ & $\begin{array}{c}0.00302 \\
(0.00605)\end{array}$ & $\begin{array}{c}0.00279 \\
(0.00604)\end{array}$ \\
\hline Stressed Bank $_{b} *$ Low Liquidity ${ }_{j, t} * \mathrm{RF}_{t}^{\text {Post } 2013}$ & $\begin{array}{r}-0.00489 \\
(0.00625) \\
\end{array}$ & $\begin{array}{l}-0.00458 \\
(0.00620) \\
\end{array}$ & $\begin{array}{c}0.00323 \\
(0.00598) \\
\end{array}$ & $\begin{array}{c}0.00361 \\
(0.00598) \\
\end{array}$ \\
\hline No. of Observations & 24136 & 24136 & 27002 & 27002 \\
\hline $\mathrm{R}^{2}$ & 0.436 & 0.439 & 0.850 & 0.851 \\
\hline Borrower FE & $\mathrm{Y}$ & $\mathrm{Y}$ & $\mathrm{Y}$ & Y \\
\hline Year FE & $\mathrm{N}$ & $\mathrm{Y}$ & $\mathrm{N}$ & $\mathrm{Y}$ \\
\hline Bank FE & $\mathrm{N}$ & Y & $\mathrm{N}$ & Y \\
\hline
\end{tabular}

Standard errors in parentheses; ${ }^{*} p<0.10,{ }^{* *} p<0.05,{ }^{* * *} p<0.01$.

The total number of firm-year observations in the full sample are 38,016 .

Notes: This table summarizes the real effects of regulatory forbearance on capital and employment for low-solvency (panel A) and low-liquidity (panel B) firms at stressed banks using a triple difference specification. Panel A shows the results for low-solvency firms and Panel B shows the results for low-liquidity firms. In columns 1-2 the dependent variable is the capex ratio defined as the proportion of change in gross fixed assets out of total assets of a firm in period $\mathrm{T}+1$. Columns 3-4 show the results for expenditure on employment as proxied by the proportion of wages in the total expenses of a firm in period $\mathrm{T}+1$. A bank is classified as Stressed Bank if the proportion of non-performing loans in the total gross advances (loans) for the bank is in the top two terciles in 2007 i.e. before the introduction of forbearance policy by RBI. A firm is classified as Low Solvency if the Debt to equity measure of the firm in time period $\mathrm{T}$ is above median. A firm is classified as Low Liquidity if the cash ratio measure of the firm in time period $\mathrm{T}$ is below median. The indicator variable Forbearance ${ }^{\text {Post } 2008}$ takes a value 1 in the years Post 2008 i.e. after the introduction of forbearance. The indicator variable Forbearance ${ }^{\text {Post } 2013}$ takes a value 1 in the years Post 2013 i.e. after the announcement of withdrawal of forbearance by RBI. Only the triple interaction terms are shown though remaining interaction terms, not absorbed by the fixed effects, are also included but not shown for brevity. All specifications control for time invariant borrower characteristics and time varying firm size via Log of Sales. Borrower, year, and bank fixed effects are as indicated. Standard errors are clustered at firm level. 
Table 7: Identification Using Proximity to the Regulator: Firms Borrowing from State-owned Banks

\begin{tabular}{|c|c|c|c|c|c|c|}
\hline Dependent Variable: $\log$ Debt $_{j, t+1}$ & (1) & $(2)$ & $(3)$ & $(4)$ & $(5)$ & (6) \\
\hline Regulator Proximity $_{b} *$ Low Solvency $_{j, t} *$ Forbearance $_{t}^{\text {Post } 2008}$ & $\begin{array}{l}0.318^{* * *} \\
(0.118)\end{array}$ & $\begin{array}{l}0.328^{* * *} \\
(0.117)\end{array}$ & & & & \\
\hline Regulator Proximity $_{b} *$ Low Solvency $_{j, t} *$ Forbearance $_{t}$ Post 2013 & $\begin{array}{l}-0.116 \\
(0.105)\end{array}$ & $\begin{array}{l}-0.118 \\
(0.103)\end{array}$ & & & & \\
\hline Regulator Proximity $_{b} *$ Low Liquidity $_{j, t} *$ Forbearance $_{t}^{\text {Post } 2008}$ & & & $\begin{array}{l}0.251^{* * *} \\
(0.0891)\end{array}$ & $\begin{array}{l}0.257^{* * *} \\
(0.0887)\end{array}$ & & \\
\hline Regulator Proximity $_{b} *$ Low Liquidity $_{j, t} *$ Forbearance $_{t}$ Post 2013 & & & $\begin{array}{c}-0.0553 \\
(0.105)\end{array}$ & $\begin{array}{r}-0.0356 \\
(0.104)\end{array}$ & & \\
\hline Regulator Proximity $_{b} *$ Zombie $_{j, t} *$ Forbearance $_{t}^{\text {Post } 2008}$ & & & & & $\begin{array}{l}0.227^{* *} \\
(0.102)\end{array}$ & $\begin{array}{l}0.249^{* *} \\
(0.101)\end{array}$ \\
\hline Regulator Proximity $_{b} *$ Zombie $_{j, t} *$ Forbearance $_{t}^{\text {Post } 2013}$ & & & & & $\begin{array}{c}-0.107 \\
(0.108)\end{array}$ & $\begin{array}{c}-0.101 \\
(0.107)\end{array}$ \\
\hline No. of Obs. & 16495 & 16495 & 18086 & 18086 & 18114 & 18114 \\
\hline R-sq. & 0.936 & 0.937 & 0.932 & 0.933 & 0.935 & 0.935 \\
\hline Borrower FE & $\mathrm{Y}$ & $\mathrm{Y}$ & $\mathrm{Y}$ & $\mathrm{Y}$ & $\mathrm{Y}$ & $\mathrm{Y}$ \\
\hline Year FE & $\mathrm{N}$ & $\mathrm{Y}$ & $\mathrm{N}$ & $\mathrm{Y}$ & $\mathrm{N}$ & $\mathrm{Y}$ \\
\hline Bank FE & $\mathrm{N}$ & $\mathrm{Y}$ & $\mathrm{N}$ & $\mathrm{Y}$ & $\mathrm{N}$ & $\mathrm{Y}$ \\
\hline
\end{tabular}

Standard errors in parentheses; ${ }^{*} p<0.10,{ }^{* *} p<0.05,{ }^{* * *} p<0.01$

The total number of firm-year observations in the full sample are 38,016.

Notes: This table summarizes the impact of regulatory forbearance on lending to low-solvency (columns 1-2), low-liquidity firms (columns 3-4), and zombie (columns 5-6) firms with proximity to the regulator for the subset of firms that borrow from state-owned banks. The dependent variable is the Log of Debt of a firm in period $\mathrm{T}+1$. A firm is classified as Zombie if the the firm received subsidized credit in time period T i.e. the firm is able to borrow loans at an average interest rate that is lower than the Prime Lending Rate (PLR) of State Bank of India and has Debt to Assets ratio > .15. A firm is classified as Low Solvency if the Debt to equity measure of the firm in time period $\mathrm{T}$ is above median. A firm is classified as Low Liquidity if the cash ratio measure of the firm in time period $\mathrm{T}$ is below median. Regulator Proximity ${ }_{b}$ is 1 if the distance of the bank headquarters is below the median value and 0 otherwise. Only the triple interaction terms are shown though remaining interaction terms, not absorbed by the fixed effects, are also included but not shown for brevity. All specifications control for time-invariant borrower characteristics and time-varying firm size via log of sales.

Borrower, year, and bank fixed effects are as indicated. Standard errors are clustered at firm level. 


\title{
The Unholy Trinity: Regulatory Forbearance, Stressed Banks and Zombie Firms
}

\section{Online Appendix}

\author{
Anusha Chari Lakshita Jain Nirupama Kulkarni
}




\section{Appendix IA.1 Loan Recovery Processes Prior to the GFC}

India did not implement an effective and comprehensive bankruptcy framework until 2016 (Insolvency and Bankruptcy Code and Bank Recapitalisation, 2017). Prior to this, and in the absence of the requisite legal apparatus for resolving stressed assets, the central bank resorted to makeshift arrangements with out-of-court resolutions that mimicked formal bankruptcy laws. Not surprisingly, India has consistently ranked very low in global rankings of loan recovery prospects and the time taken for the resolution of stressed-assets.

Debt Recovery Tribunals (established under the "Recovery of Debts due to Banks and Financial Institutions Act of 1993") were established to help banks and financial institutions recover their dues speedily without being subject to the lengthy procedures of the civil courts (See The Indian Express, 2018 for a perspective on bad loan problem) ${ }^{38}$ Subsequently, the SARFAESI Act of 2002 allowed banks and other financial institutions to auction off the residential or commercial properties of defaulters to recover loans. In addition, the RBI introduced the Corporate Debt Restructuring mechanism in 2001 to allow syndicates or consortium of lenders to restructure the debt of corporate firms.

The policy specifically targeted multiple banking accounts along with syndication/consortium accounts of corporate borrowers with outstanding exposures to banks and other financial institutions exceeding Rs.10 crores (roughly US $\$ 1.35$ million). Recognizing the difficulties in reaching an agreement among different lending institutions, the policy specifically targeted exposures involving more than one lender under a consortium or multiple banking arrangements. The rationale for the restructuring mechanism was to allow loans to otherwise viable firms to be restructured through an orderly and coordinated program to help minimize losses to the both borrowers and creditors.

Criticism arose that the provisions of SARFAESI Act were not being used properly by banks and recovery rates were a mere $13 \%$ of the original amounts at stake in 2013-14. Influential promoters could still play off one bank against another by choosing to repay some loans while strategically defaulting on others. Many listed firms in India are backed by promoters who are a set of persons and/or families that effectively control the firm. The term 'promoter' is defined under Section 2(69) of the Companies Act, 2013 and Regulation 2(1)(za) of the Securities and Exchange Board of India (Issue of Capital and Disclosure Requirements) Regulations, 2009 to broadly mean persons having 'control' over a company (Faculty of Law, University of Oxford, 2016) 39 Overall, banks were not backed by the regulators in their efforts to recover outstanding loans, particularly those given to politically-connected promoters.

\footnotetext{
${ }^{38}$ See the article by Dr Raghuram Rajan for a perspective on bad loan problem at https://indianexpress.com/article/explained/raghuram-rajan-bad-loans-npa-indian-banking-systemeconomy-5351347/

${ }^{39}$ https://www.law.ox.ac.uk/business-law-blog/blog/2016/12/promoter-exits-india-real-leash-reinedmarket-watchdog
} 
Figure IA.1: Recent Banking Trends in India

Notes: This figure shows the aggregate growth trends in assets, credit, deposits and non-performing assets of the banks in India for the period 2013-2017. Panel (a) shows the aggregate growth trends of assets, credit, deposits and gross non-performing asset (GNPA) ratio for the banks in India for the period 2013-2017. GNPA ratio is the proportion of non-performing assets to gross advances (loans). Panel (b) shows the growth in advances (loans) by bank-type. Bank types are public, private, and foreign banks. Public banks are banks with majority government ownership. Classification for bank-types is from DBIE.

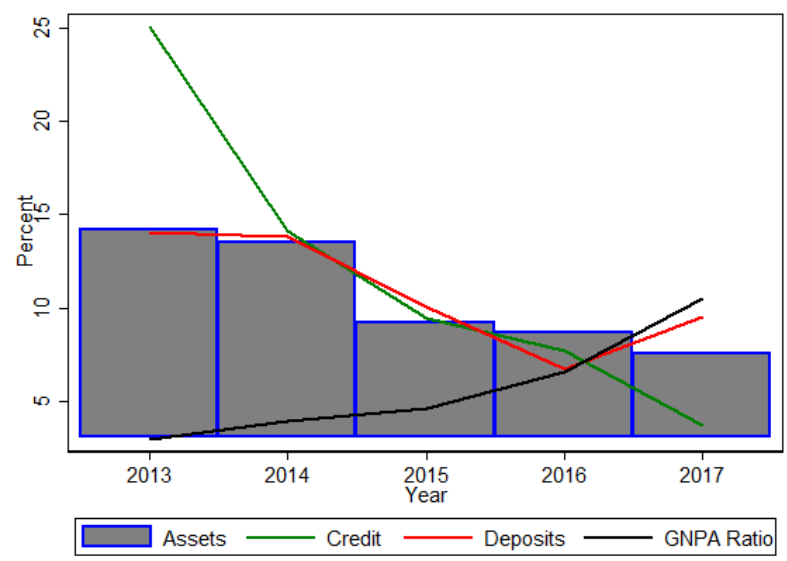

(a) Aggregate Growth

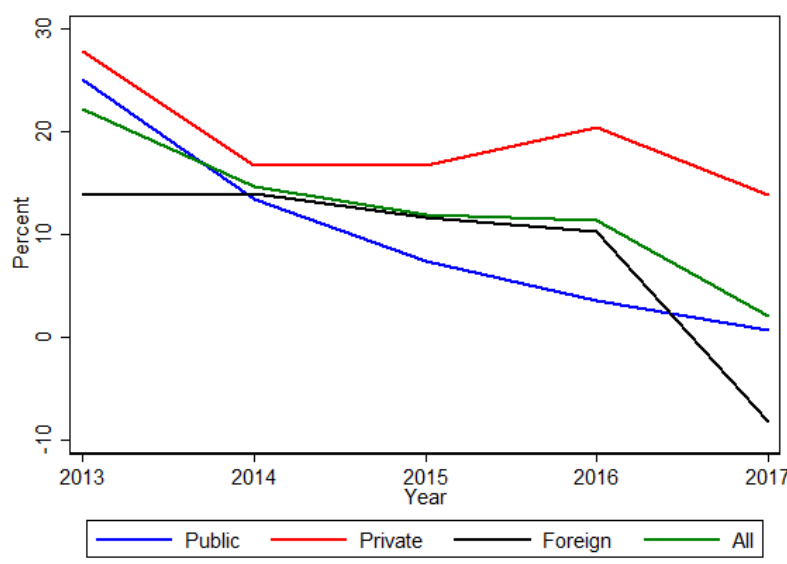

(b) Gross Advances by Bank Type 
Figure IA.2: Relationship between Bank Capital and Bank-level Zombie Proportion

Notes: This figure plots the time-series trend in bank capital and the proportion of zombie firms in the bank's portfolio for the years 2006-2016. The y-axis on the left-hand-side measures the average proportion of zombies in a bank's portfolio and the y-axis on the right-hand-side measures the average bank capital ratio (CRAR Tier I). The horizontal line at $9 \%$ refers to the stipulated minimum capital ratio.

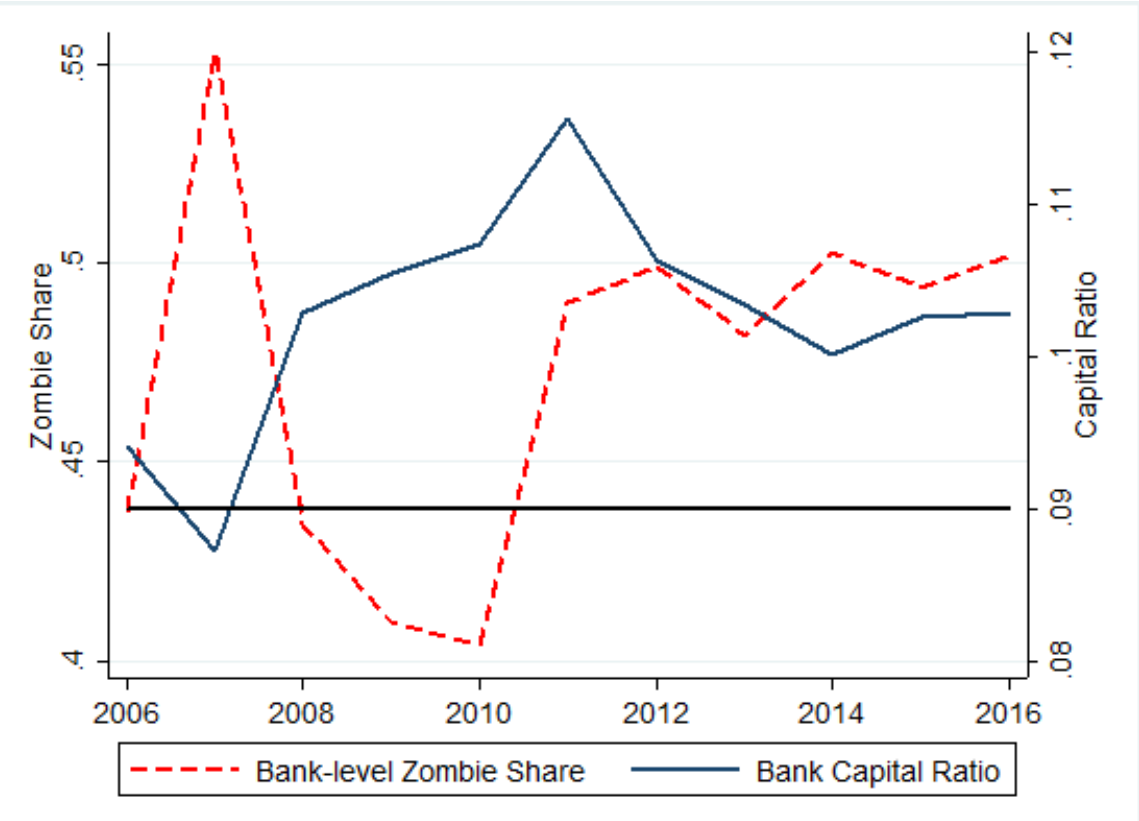


Table IA.1: Characteristics of Zombie Firms

\begin{tabular}{|c|c|c|c|c|c|c|}
\hline Dependent Variable: Zombie ${ }_{j, t}$ & $(1)$ & $(2)$ & $(3)$ & $(4)$ & $(5)$ & $(6)$ \\
\hline Manufacturing firm & $\begin{array}{c}0.234^{* * *} \\
(0.00985)\end{array}$ & & & & & $\begin{array}{l}0.231^{* * *} \\
(0.0113)\end{array}$ \\
\hline Infrastructure firm & & $\begin{array}{c}-0.119^{* * *} \\
(0.0127)\end{array}$ & & & & $\begin{array}{c}0.0407^{* * *} \\
(0.0144)\end{array}$ \\
\hline Young & & & $\begin{array}{c}-0.164^{* * *} \\
(0.0141)\end{array}$ & & & $\begin{array}{c}-0.0791^{\text {*** }} \\
(0.0143)\end{array}$ \\
\hline Listed firms & & & & $\begin{array}{c}0.127^{* * *} \\
(0.00940)\end{array}$ & & $\begin{array}{c}0.0819^{* * *} \\
(0.00963)\end{array}$ \\
\hline Size & & & & & $\begin{array}{l}0.206^{* * *} \\
(0.0198)\end{array}$ & $\begin{array}{l}0.121^{* * *} \\
(0.0198)\end{array}$ \\
\hline No. of Obs. & 38324 & 38324 & 39227 & 39227 & 39227 & 38324 \\
\hline R-sq. & 0.0547 & 0.00858 & 0.00549 & 0.0160 & 0.00860 & 0.0691 \\
\hline
\end{tabular}

Standard errors in parentheses; ${ }^{*} p<0.10,{ }^{* *} p<0.05,{ }^{* * *} p<0.01$

Notes: This table summarizes the characteristics of zombie firms. Columns 1-5 shows coefficients from uni-variate regressions. Column 6 shows coefficients for the horse-race regression including all the variables. The dependent variable in all columns is whether a firm is classified as a zombie in a given year. A firm is classified as Zombie if the the firm received subsidized credit in time period T i.e. the firm is able to borrow loans at an average interest rate that is lower than the Prime Lending Rate (PLR) of State Bank of India and has Debt to Assets ratio $>$.15. Manufacturing firm is a dummy variable that takes the value 1 if a firm is a manufacturing firm. Similarly, Infrastructure firm and Listed firms are dummy variables that take the value 1 if a firm is an infrastructure firm and listed firm respectively. Young is a dummy variable that takes the value 1 for firms with age less than 5 years. Size is proxied by the log of the assets of the firm. Standard errors are clustered at the firm-level. 
Table IA.2: Heterogeneity in the Impact of Forbearance for Public and Private Sector Banks

\begin{tabular}{lcc}
\hline Dependent Variable: Log Debt $_{j, t+1}$ & $(1)$ & $(2)$ \\
\hline Public Bank $_{b} *$ Zombie $_{j, t} *$ Forbearance $_{t}{ }^{\text {Post 2008 }}$ & $0.229^{*}$ & $0.256^{* *}$ \\
Public Bank $_{b} *$ Zombie $_{j, t} *$ Forbearance $_{t}{ }^{\text {Post } 2013}$ & $(0.128)$ & $(0.128)$ \\
& 0.132 & 0.134 \\
No. of Obs. & $(0.100)$ & $(0.101)$ \\
R-sq. & 24126 & 24126 \\
Borrower FE & 0.930 & 0.931 \\
Year FE & $\mathrm{Y}$ & $\mathrm{Y}$ \\
Bank FE & $\mathrm{N}$ & $\mathrm{Y}$ \\
\hline
\end{tabular}

Standard errors in parentheses; ${ }^{*} p<0.10,{ }^{* *} p<0.05,{ }^{* * *} p<0.01$

The total number of firm-year observations in the full sample are 38,016 .

Notes: This table summarizes the direct effects (columns 1-2) on debt for public and private sector banks using a triple difference specification. Public banks are banks with majority government ownership.

Classification for public and private sector banks is from DBIE. The dependent variable in the columns is the firm-level log of debt in $\mathrm{T}+1$. A firm is classified as Zombie if the the firm received subsidized credit in time period $\mathrm{T}$ i.e. the firm is able to borrow loans at an average interest rate that is lower than the Prime Lending Rate (PLR) of State Bank of India and has Debt to Assets ratio > .15. Public Bank is 1 for public sector banks. The indicator variable Forbearance ${ }^{\text {Post } 2008}$ takes a value 1 in the years Post 2008 i.e. after the introduction of Forbearance. The indicator variable Forbearance ${ }^{\text {Post } 2013}$ takes a value 1 in the years Post 2013 i.e. after the announcement of withdrawal of Forbearance by RBI. Only the triple interaction terms are shown though remaining interaction terms, not absorbed by the fixed effects, are also included but not shown for brevity. All specifications control for time-invariant borrower characteristics and time-varying firm size via $\log$ of sales. Bank fixed effects are as indicated. Standard errors are clustered at firm level. 
Table IA.3: The Impact on New Banking Relationships of Healthy Firms

\begin{tabular}{|c|c|c|c|}
\hline Dependent Variable: New banking relationship $_{j, t+1}$ & $(1)$ & $(2)$ & $(3)$ \\
\hline 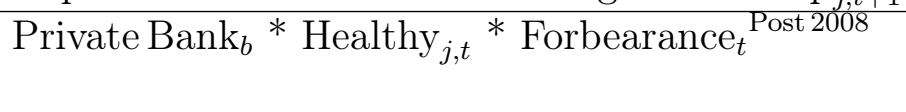 & $\begin{array}{c}0.0438^{* * *} \\
(0.0132)\end{array}$ & $\begin{array}{c}0.0441^{* * *} \\
(0.0132)\end{array}$ & $\begin{array}{c}0.0414^{\text {*** }} \\
(0.0132)\end{array}$ \\
\hline Foreign Bank $_{b} *$ Healthy $_{j, t} *$ Forbearance $_{t}$ Post 2008 & $\begin{array}{c}0.0978^{* * *} \\
(0.0246)\end{array}$ & $\begin{array}{c}0.0987^{* * *} \\
(0.0247)\end{array}$ & $\begin{array}{l}0.110^{* * *} \\
(0.0247)\end{array}$ \\
\hline Others $_{b} *$ Healthy $_{j, t} *$ Forbearance $_{t}$ Post 2008 & $\begin{array}{c}0.0288 \\
(0.0316)\end{array}$ & $\begin{array}{c}0.0292 \\
(0.0318)\end{array}$ & $\begin{array}{c}0.0404 \\
(0.0316)\end{array}$ \\
\hline Private Bank $_{b} *$ Healthy $_{j, t} *$ Forbearance $_{t}$ Post 2013 & $\begin{array}{l}-0.0169^{*} \\
(0.00909)\end{array}$ & $\begin{array}{l}-0.0179^{*} \\
(0.00917)\end{array}$ & $\begin{array}{l}-0.0154^{*} \\
(0.00911)\end{array}$ \\
\hline Foreign Bank $_{b} *$ Healthy $_{j, t} *$ Forbearance $_{t}$ Post $_{2013}$ & $\begin{array}{l}0.00628 \\
(0.0186)\end{array}$ & $\begin{array}{l}0.00545 \\
(0.0188)\end{array}$ & $\begin{array}{c}0.0100 \\
(0.0188)\end{array}$ \\
\hline Others $_{b} *$ Healthy $_{j, t} *$ Forbearance $_{t}^{\text {Post } 2013}$ & $\begin{array}{l}0.0590^{* *} \\
(0.0290)\end{array}$ & $\begin{array}{l}0.0580^{* *} \\
(0.0294)\end{array}$ & $\begin{array}{c}0.0455^{*} \\
(0.0244)\end{array}$ \\
\hline No. of Obs. & 124170 & 124170 & 123999 \\
\hline R-sq. & 0.131 & 0.133 & 0.161 \\
\hline Borrower FE & Y & Y & Y \\
\hline Year FE & $\mathrm{N}$ & Y & Y \\
\hline Bank FE & $\mathrm{N}$ & $\mathrm{N}$ & Y \\
\hline
\end{tabular}

Standard errors in parentheses; ${ }^{*} p<0.10,{ }^{* *} p<0.05,{ }^{* * *} p<0.01$

Notes: This table summarizes the probability of entry regression specification using a triple difference specification. The dependent variable is a dummy indicating firm entry in period $T+1$. A firm is classified as $Z$ ombie if the the firm received subsidized credit in time period $T$ i.e. the firm is able to borrow loans at an average interest rate that is lower than the Prime Lending Rate (PLR) of State Bank of India and has Debt to Assets ratio > .15 and Healthy otherwise. Private Bank is an indicator variable which takes the value 1 for private sector Banks, Foreign Bank is an indicator variable which takes the value 1 for foreign Banks, and Other is an indicator variable which takes the value 1 for all other non-bank lenders. Public banks are banks with majority government ownership. Classification for bank-type is from DBIE. The indicator variable Forbearance ${ }^{\text {Post } 2008}$ takes a value 1 in the years Post 2008 i.e. after the introduction of Forbearance. The indicator variable Forbearance ${ }^{\text {Post } 2013}$ takes a value 1 in the years Post 2013 i.e. after the announcement of withdrawal of Forbearance by RBI. Only the triple interaction terms are shown though remaining interaction terms, not absorbed by the fixed effects, are also included but not shown for brevity. All specifications control for time invariant borrower characteristics and time varying firm size via log of sales. Borrower, year, and bank fixed effects are as indicated. Standard errors are clustered at firm level. 
Table IA.4: The Impact of Forbearance on Low-solvency and High-liquidity Firms

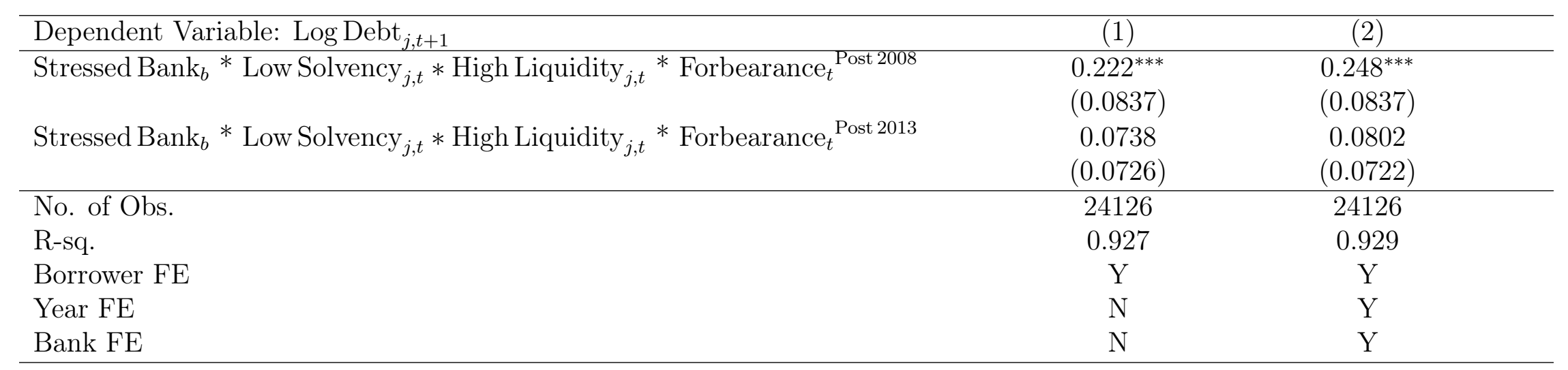

The total number of firm-year observations in the full sample are 38,016.

Notes: This table summarises the results of the regression examining the impact of regulatory forbearance for low solvency and high liquidity firms. The dependent variable is log of debt of a firm in period T +1 . A bank is classified as Stressed Bank if the proportion of non-performing loans in the total gross advances lent out by the bank is in top two terciles in the year 2007 i.e. before the introduction of forbearance policy by RBI. A firm is classified as Low Solvency if the Debt to equity measure of the firm in time period T is above median. A firm is classified as Low Liquidity if the cash ratio measure of the firm in time period $\mathrm{T}$ is below median. The indicator variable Forbearance ${ }^{\text {Post } 2008}$ takes a value 1 in the years post 2008 i.e. after the introduction of forbearance. The indicator variable Forbearance ${ }^{\text {Post } 2013}$ takes a value 1 in the years post 2013 i.e. after the announcement of withdrawal of forbearance by RBI. Only the quadruple interaction terms are shown though remaining interaction terms, not absorbed by the fixed effects, are also included but not shown for brevity. All specifications control for time invariant borrower characteristics and time varying firm size via Log of Sales.

Remaining interaction variables are included but not shown. Borrower, year, and bank fixed effects are as indicated. Standard errors are clustered at firm level. 
Table IA.5: Are Firms Able to Switch to Borrowing from Bond Markets?

\begin{tabular}{|c|c|c|}
\hline Dependent Variable: Log Debt $_{j, t+1}$ & $(1)$ & $(2)$ \\
\hline Stressed Bank $_{b} *$ Zombie $_{j, t} *$ Forbearance $_{t}^{\text {Post } 2008}$ & $\begin{array}{c}0.303^{* * *} \\
(0.104)\end{array}$ & $\begin{array}{c}0.319^{* * *} \\
(0.103)\end{array}$ \\
\hline Stressed Bank $_{b} *$ Zombie $_{j, t} *$ Bond $_{j, t} *$ Forbearance $_{t}{ }^{\text {Post } 2008}$ & $\begin{array}{c}0.456 \\
(1.716)\end{array}$ & $\begin{array}{c}0.623 \\
(1.661)\end{array}$ \\
\hline Stressed Bank $_{b} *$ Zombie $_{j, t} *$ Forbearance $_{t}^{\text {Post } 2013}$ & $\begin{array}{c}0.00287 \\
(0.0910)\end{array}$ & $\begin{array}{c}0.0180 \\
(0.0910)\end{array}$ \\
\hline Stressed Bank $_{b} *$ Zombie $_{j, t} *$ Bond $_{j, t} *$ Forbearance $_{t}{ }^{\text {Post } 2013}$ & $\begin{array}{c}0.347 \\
(1.055)\end{array}$ & $\begin{array}{c}0.291 \\
(1.045)\end{array}$ \\
\hline No. of Obs. & 24126 & 24126 \\
\hline R-sq. & 0.930 & 0.931 \\
\hline Borrower FE & Y & Y \\
\hline Year FE & $\mathrm{N}$ & Y \\
\hline Bank FE & $\mathrm{N}$ & Y \\
\hline
\end{tabular}

Standard errors in parentheses; ${ }^{*} p<0.10,{ }^{* *} p<0.05,{ }^{* * *} p<0.01$

The total number of firm-year observations in the full sample are 38,016 .

Notes: This table summarises the effects of access to the corporate bond markets. The dependent variable is log of debt of a firm in period $\mathrm{T}+1$. A firm is classified as Zombie if the the firm received subsidized credit in time period T i.e. the firm is able to borrow loans at an average interest rate that is lower than the Prime Lending Rate (PLR) of State Bank of India and has Debt to Assets ratio > .15. A bank is classified as Stressed Bank if the proportion of non-performing loans in the total gross advances (loans) for the bank is in the top two terciles in the year 2007 i.e. before the introduction of Forbearance policy by RBI. The indicator variable Forbearance ${ }^{\text {Post } 2008}$ takes a value 1 in the years Post 2008 i.e. after the introduction of Forbearance. The indicator variable Forbearance ${ }^{\text {Post } 2013}$ takes a value 1 in the years Post 2013 i.e. after the announcement of withdrawal of Forbearance by RBI. Bond $j t$ is a dummy variable which takes the value 1 if a firm has accessed bond markets in the year T. Only the triple interaction terms are shown though remaining interaction terms, not absorbed by the fixed effects, are also included but not shown for brevity. All specifications control for time invariant borrower characteristics and time varying firm size via log of sales. Borrower, year, and bank fixed effects are as indicated. Standard errors are clustered at firm level. 
Table IA.6: Alternative Zombie Measure: Accounting for Firm Distress

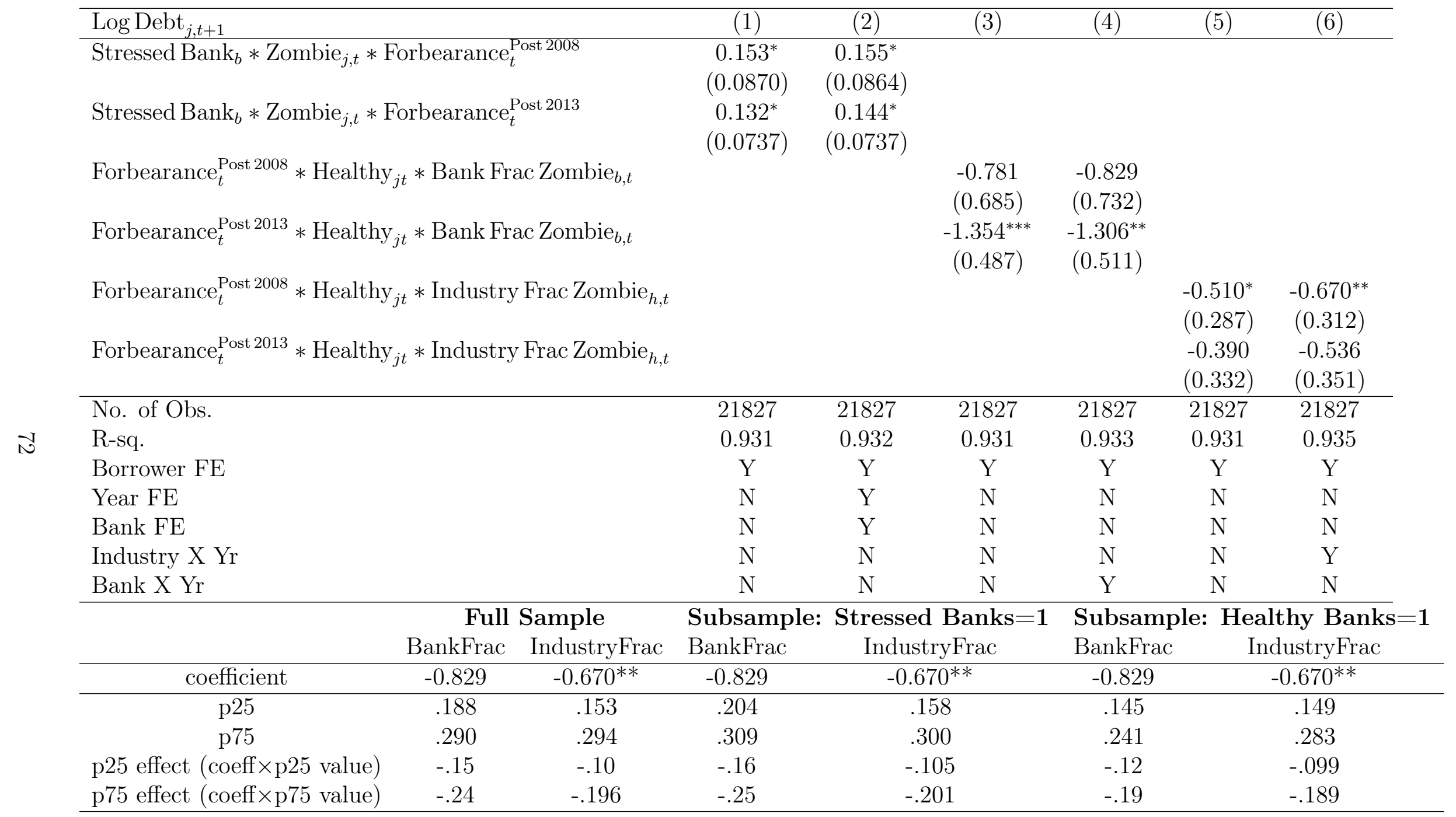

Standard errors in parentheses; ${ }^{*} p<0.10,{ }^{* *} p<0.05,{ }^{* * *} p<0.01$. The total number of firm-year observations in the full sample are 38,016 . 
Notes: This table summarizes the direct (columns 1-2) and spillover effects (columns 3-6) of regulatory forbearance on debt using a triple difference specification and an alternate zombie measure. The dependent variable in all columns is the firm-level log of debt in $T+1$. A firm is classified as Zombie if the the firm received subsidized credit in time period T i.e. the firm is able to borrow loans at an average interest rate that is lower than the Prime Lending Rate (PLR) of State Bank of India, has Debt to Assets ratio > .15 and has an interest coverage ratio below 2. A bank is classified as Stressed Bank if the proportion of non-performing loans in the total gross advances (loans) for the bank is in the top two terciles in 2007 i.e. before the introduction of Forbearance policy by RBI. The indicator variable Forbearance ${ }^{\text {Post } 2008}$ takes a value 1 in the years Post 2008 i.e. after the introduction of Forbearance. The indicator variable Forbearance ${ }^{\text {Post } 2013}$ takes a value 1 in the years Post 2013 i.e. after the announcement of withdrawal of Forbearance by RBI. Industry Frac Zombie Z $_{h, t}$ is the fraction of total firms classified as a zombie in an industry in a period T. Bank Frac Zombie ${ }_{b, t}$ is the fraction of total firms classified as a zombie in an bank's portfolio in a period T. Only the triple interaction terms are shown though remaining interaction terms, not absorbed by the fixed effects, are also included but not shown for brevity. All specifications control for time-invariant borrower characteristics and time-varying firm size via log of sales. Borrower, year, industry-year and bank fixed effects are as indicated. Standard errors are clustered at firm level. 
Table IA.7: Alternative Zombie Measure: IMF Speculative Credit Definition

\begin{tabular}{|c|c|c|c|c|c|c|c|c|}
\hline \multicolumn{3}{|l|}{$\log _{\text {Debt }_{j, t+1}}$} & (1) & $(2)$ & (3) & (4) & $(5)$ & (6) \\
\hline \multicolumn{3}{|c|}{ Stressed Bank $_{b} *$ Zombie $_{j, t} *$ Forbearance $_{t}^{\text {Post } 2008}$} & $\begin{array}{l}0.194^{* *} \\
(0.0984)\end{array}$ & $\begin{array}{c}0.200^{* *} \\
(0.0982)\end{array}$ & & & & \\
\hline \multicolumn{3}{|c|}{ Stressed Bank $_{b} *$ Zombie $_{j, t} *$ Forbearance $_{t}^{\text {Post } 2013}$} & $\begin{array}{c}0.106 \\
(0.0879)\end{array}$ & $\begin{array}{c}0.108 \\
(0.0875)\end{array}$ & & & & \\
\hline \multicolumn{3}{|c|}{ Forbearance $_{t}^{\text {Post } 2008} *$ Healthy $_{j t} *$ Bank Frac Zombie $_{b, t}$} & & & $\begin{array}{l}-0.459 \\
(0.555)\end{array}$ & $\begin{array}{l}-0.183 \\
(0.528)\end{array}$ & & \\
\hline \multicolumn{3}{|c|}{ Forbearance $_{t}^{\text {Post } 2013} *$ Healthy $_{j t} *$ Bank Frac Zombie $_{b, t}$} & & & $\begin{array}{l}-0.776^{*} \\
(0.406)\end{array}$ & $\begin{array}{l}-0.723^{*} \\
(0.410)\end{array}$ & & \\
\hline \multicolumn{3}{|c|}{ Forbearance $_{t}^{\text {Post } 2008} *$ Healthy $_{j t} *$ Industry Frac Zombie $_{h, t}$} & & & & & $\begin{array}{l}-0.307 \\
(0.274)\end{array}$ & $\begin{array}{l}-0.543^{*} \\
(0.306)\end{array}$ \\
\hline \multicolumn{3}{|c|}{ Forbearance $_{t}^{\text {Post } 2013} *$ Healthy $_{j t} *{\text { Industry Frac } \text { Zombie }_{h, t}}$} & & & & & $\begin{array}{c}-0.133 \\
(0.280)\end{array}$ & $\begin{array}{l}-0.178 \\
(0.314)\end{array}$ \\
\hline \multicolumn{3}{|l|}{ No. of Obs. } & 20609 & 20609 & 20609 & 20609 & 20609 & 20609 \\
\hline \multicolumn{3}{|l|}{ R-sq. } & 0.933 & 0.935 & 0.933 & 0.936 & 0.933 & 0.937 \\
\hline \multicolumn{3}{|l|}{ Industry X Yr } & $\mathrm{N}$ & $\mathrm{N}$ & $\mathrm{N}$ & $\mathrm{Y}$ & $\mathrm{N}$ & $\mathrm{N}$ \\
\hline \multirow[t]{3}{*}{ Bank X Yr } & \multirow{2}{*}{\multicolumn{2}{|c|}{ Full Sample }} & $\mathrm{N}$ & $\mathrm{N}$ & $\mathrm{N}$ & $\mathrm{N}$ & $\mathrm{N}$ & $\mathrm{Y}$ \\
\hline & & & Subsample & Stressec & Banks $=1$ & Subsar & ple: $\mathrm{He}$ & lthy Banks $=1$ \\
\hline & BankFrac & IndustryFrac & BankFrac & Indust & yFrac & BankFr & & dustryFrac \\
\hline coefficient & -0.183 & $-0.543^{*}$ & -0.183 & -0.5 & & -0.183 & & $-0.543^{*}$ \\
\hline $\mathrm{p} 25$ & .280 & .212 & .340 & & & .181 & & .204 \\
\hline p75 & .426 & .459 & .448 & & & .337 & & .430 \\
\hline p25 effect (coeff $\times$ p25 value) & -.05 & -.11 & -.06 & & & -.03 & & -.11 \\
\hline p75 effect (coeff $\times$ p75 value) & -.07 & -.24 & -.08 & & & -.061 & & -.23 \\
\hline
\end{tabular}

Standard errors in parentheses; ${ }^{*} p<0.10,{ }^{* *} p<0.05,{ }^{* * *} p<0.01$. The total number of firm-year observations in the full sample are 38,016 . 
Notes: This table summarizes the direct (columns 1-2) and spillover effects (columns 3-6) of regulatory forbearance on debt using a triple difference specification and an alternate zombie measure. The dependent variable in all columns is the firm-level log of debt in $\mathrm{T}+1$. A bank is classified as Stressed Bank if the proportion of non-performing loans in the total gross advances (loans) for the bank is in the top two terciles in 2007 i.e. before the introduction of Forbearance policy by RBI. The indicator variable Forbearance ${ }^{\text {Post } 2008}$ takes a value 1 in the years Post 2008 i.e. after the introduction of Forbearance. The indicator variable Forbearance ${ }^{\text {Post } 2013}$ takes a value 1 in the years Post 2013 i.e. after the announcement of withdrawal of Forbearance by RBI. The IMF definition of speculative credit recipient (we call it zombie) includes a firm with an ICR less than 4.1 and a net debt-to-assets ratio greater than 0.25 . Net debt is gross debt minus cash. Industry Frac Zombie Z $_{h, t}$ is the fraction of total firms classified as a zombie in an industry in a period T. Bank Frac Zombie Z $_{b, t}$ is the fraction of total firms classified as a zombie in an bank's portfolio in a period T. Only the triple interaction terms are shown though remaining interaction terms, not absorbed by the fixed effects, are also included but not shown for brevity. All specifications control for time-invariant borrower characteristics and time-varying firm size via log of sales. Borrower, year, industry-year and bank fixed effects are as indicated. Standard errors are clustered at firm level. 
Table IA.8: Exploiting Within-firm Variation Using Restructured Loans Data

\begin{tabular}{|c|c|c|c|c|c|c|}
\hline \multirow{3}{*}{$\begin{array}{l}\text { Dependent variable: Restructured loans }{ }_{j, t} \\
\text { Zombie definition: }\end{array}$} & (1) & $(2)$ & (3) & (4) & $(5)$ & (6) \\
\hline & Log amt. & $\log \#$ & Log amt. & $\log \#$ & Log amt. & $\log \#$ \\
\hline & \multicolumn{2}{|c|}{ Baseline } & \multicolumn{2}{|c|}{ Refined measure } & \multicolumn{2}{|c|}{ IMF definition } \\
\hline \multirow{2}{*}{ Stressed Bank $_{b} *$ Zombie $_{j, t} *$ Forbearance $_{t}^{\text {Post } 2008}$} & 0.24 & 0.01 & $0.56^{* *}$ & $0.03^{* *}$ & 0.23 & 0.01 \\
\hline & $(0.26)$ & $(0.01)$ & $(0.27)$ & $(0.01)$ & $(0.26)$ & $(0.01)$ \\
\hline \multirow{2}{*}{ Stressed Bank $_{b} *$ Zombie $_{j, t} *$ Forbearance $_{t}^{\text {Post } 2013}$} & 0.11 & -0.00 & $-0.46^{* *}$ & $-0.02^{* *}$ & -0.03 & -0.01 \\
\hline & $(0.24)$ & $(0.01)$ & $(0.23)$ & $(0.01)$ & $(0.21)$ & $(0.01)$ \\
\hline No. of Obs. & 49940 & 49940 & 49940 & 48246 & 48246 & 48246 \\
\hline R-sq. & 0.60 & 0.63 & 0.60 & 0.63 & 0.60 & 0.63 \\
\hline Firm X Yr & Y & Y & Y & $\mathrm{Y}$ & Y & $\mathrm{Y}$ \\
\hline Bank Group X Yr & Y & Y & Y & Y & Y & $\mathrm{Y}$ \\
\hline
\end{tabular}

Standard errors in parentheses; ${ }^{*} p<0.10,{ }^{* *} p<0.05,{ }^{* * *} p<0.01$.

Notes: This table shows the effect of regulatory forbearance on restructured loans for the period T-1 to T using loan-level data on restructured loans using 3 different zombie measures. The dependent variable in columns 1, 3, and 6 is the logarithm of the total restructured loans by bank group (stressed/non-stressed) for each firm in a given year. In columns 2, 4, and 6 the dependent variable is the $\log$ of the corresponding total number of restructured loans. A bank is classified as Stressed Bank if the proportion of non-performing loans in the total gross advances (loans) for the bank is in the top two terciles in the year 2007 i.e. before the introduction of Forbearance policy by RBI. The indicator variable Forbearance ${ }^{\text {Post } 2008}$ takes a value 1 in the years Post 2008 i.e. after the introduction of Forbearance. The indicator variable Forbearance ${ }^{\text {Post } 2013}$ takes a value 1 in the years Post 2013 i.e. after the announcement of withdrawal of Forbearance by RBI. The baseline zombie measure in columns $1-2$ is as defined in Table 5 . The zombie measure in columns 3-4 is as defined in Table IA.6. The zombie measure in columns 5-6 is as defined in Table IA.7. Only the triple interaction terms are shown though remaining interaction terms, not absorbed by the fixed effects, are also included but not shown for brevity. All specifications include borrower-year fixed effects and the bank group-year fixed effects. Data on restructured loans is from the Ministry of Corporate Affairs. Standard errors are clustered at firm level. 
Table IA.9: The Impact on Borrowings of Low-solvency, Low-liquidity, and Zombie Firms by Bank Capitalization

\begin{tabular}{|c|c|c|c|c|c|c|}
\hline Dependent Variable: Log Debt $_{j, t+1}$ & (1) & $(2)$ & $(3)$ & $(4)$ & $(5)$ & (6) \\
\hline CRAR $_{b} *$ Low Solvency $_{j, t} *$ Forbearance $_{t}^{\text {Post } 2008}$ & $\begin{array}{c}-0.0841^{* *} \\
(0.0345)\end{array}$ & $\begin{array}{c}-0.0901^{* * *} \\
(0.0335)\end{array}$ & & & & \\
\hline CRAR $_{b} *$ Low Solvency $_{j, t} *$ Forbearance $_{t}^{\text {Post } 2013}$ & $\begin{array}{l}-0.0148 \\
(0.0216)\end{array}$ & $\begin{array}{l}-0.0117 \\
(0.0209)\end{array}$ & & & & \\
\hline $\mathrm{CRAR}_{b} *$ Low Liquidity $_{j, t} *$ Forbearance $_{t}^{\text {Post } 2008}$ & & & $\begin{array}{c}-0.0892^{* * *} \\
(0.0277)\end{array}$ & $\begin{array}{c}-0.0878^{* * *} \\
(0.0268)\end{array}$ & & \\
\hline $\mathrm{CRAR}_{b} *$ Low Liquidity $_{j, t} *$ Forbearance $_{t}{ }^{\text {Post } 2013}$ & & & 0.00620 & 0.00157 & & \\
\hline $\mathrm{CRAR}_{b} *$ Zombie $_{j, t} *$ Forbearance $_{t}$ Post 2008 & & & & & $\begin{array}{r}-0.0679^{* *} \\
(0.0295)\end{array}$ & $\begin{array}{c}-0.0716^{* *} \\
(0.0289)\end{array}$ \\
\hline $\mathrm{CRAR}_{b} *$ Zombie $_{j, t} *$ Forbearance $_{t}^{\text {Post } 2013}$ & & & & & $\begin{array}{r}-0.00721 \\
(0.0208)\end{array}$ & $\begin{array}{r}-0.00567 \\
(0.0203)\end{array}$ \\
\hline No. of Obs. & 21817 & 21817 & 24068 & 24068 & 24114 & 24114 \\
\hline R-sq. & 0.931 & 0.933 & 0.927 & 0.928 & 0.930 & 0.933 \\
\hline Borrower FE & Y & Y & Y & Y & $\mathrm{Y}$ & $\mathrm{Y}$ \\
\hline Year FE & $\mathrm{N}$ & Y & $\mathrm{N}$ & Y & $\mathrm{N}$ & Y \\
\hline Bank FE & $\mathrm{N}$ & Y & $\mathrm{N}$ & $\mathrm{Y}$ & $\mathrm{N}$ & $\mathrm{Y}$ \\
\hline
\end{tabular}

Standard errors in parentheses; ${ }^{*} p<0.10,{ }^{* *} p<0.05,{ }^{* * *} p<0.01$

The total number of firm-year observations in the full sample are 38,016 .

Notes: This table examines the impact of the regulatory forbearance on debt of low-liquidity, low-solvency, and zombie firms by bank capitalization using a triple difference specification. The dependent variable is log of debt of a firm in period $\mathrm{T}+1 \mathrm{CRAR} b$ is capital-to-risk assets ratio, which is a continuous time-varying measure of bank health. A firm is classified as Low Solvency if the Debt to equity measure of the firm in time period $\mathrm{T}$ is above median. A firm is classified as Low Liquidity if the cash ratio measure of the firm in time period $\mathrm{T}$ is below median. A firm is classified as Zombie if the the firm received subsidized credit in time period $\mathrm{T}$ i.e. the firm is able to borrow loans at an average interest rate that is lower than the Prime Lending Rate (PLR) of State Bank of India and has Debt to Assets ratio > .15. The indicator variable Forbearance ${ }^{\text {Post } 2008}$ takes a value 1 in the years post 2008 i.e. after the introduction of forbearance. The indicator variable Forbearance ${ }^{\text {Post } 2013}$ takes a value 1 in the years post 2013 i.e. after the announcement of withdrawal of forbearance by RBI. Only the triple interaction terms are shown though remaining interaction terms, not absorbed by the fixed effects, are also included but not shown for brevity. All specifications control for time invariant borrower characteristics and time varying firm size via Log of Sales. Borrower, year, and bank fixed effects are as indicated. Standard errors are clustered at the firm-level. 
Table IA.10: Robustness to Using an Alternate Measure of Forbearance (Provisioning Rates)

\begin{tabular}{|c|c|c|c|c|c|c|}
\hline Dependent Variable: $\log$ Debt $_{j, t+1}$ & $(1)$ & $(2)$ & $(3)$ & $(4)$ & $(5)$ & $(6)$ \\
\hline Stressed Bank $_{b} *$ Zombie $_{j, t} *$ Prov rate $_{t}$ & $\begin{array}{c}-0.0270^{* *} \\
(0.0116)\end{array}$ & $\begin{array}{c}-0.0305^{* * *} \\
(0.0114)\end{array}$ & & & & \\
\hline Industry Frac Zombie $_{h, t} *$ Non Zombie $_{j, t} *$ Prov rate $_{t}$ & & & $\begin{array}{l}0.0685^{* *} \\
(0.0311)\end{array}$ & $\begin{array}{c}0.0917^{* * *} \\
(0.0345)\end{array}$ & & \\
\hline Bank Frac Zombie $_{h, t} *$ Non Zombie $_{j, t} *$ Prov rate $_{t}$ & & & & & $\begin{array}{c}0.0800^{*} \\
(0.0470)\end{array}$ & $\begin{array}{c}0.0871^{*} \\
(0.0498)\end{array}$ \\
\hline No. of Obs. & 24866 & 24866 & 24866 & 24866 & 24866 & 24866 \\
\hline R-sq. & 0.928 & 0.930 & 0.928 & 0.933 & 0.928 & 0.931 \\
\hline Borrower FE & $\mathrm{Y}$ & Y & $\mathrm{Y}$ & $\mathrm{Y}$ & $\mathrm{Y}$ & $\mathrm{Y}$ \\
\hline Year FE & $\mathrm{N}$ & Y & $\mathrm{N}$ & Y & $\mathrm{N}$ & $\mathrm{Y}$ \\
\hline Industry X Year FE & $\mathrm{N}$ & $\mathrm{N}$ & $\mathrm{N}$ & $\mathrm{Y}$ & $\mathrm{N}$ & $\mathrm{N}$ \\
\hline Bank FE & $\mathrm{N}$ & Y & $\mathrm{N}$ & Y & $\mathrm{N}$ & $\mathrm{Y}$ \\
\hline Bank X Year FE & $\mathrm{N}$ & $\mathrm{N}$ & $\mathrm{N}$ & $\mathrm{N}$ & $\mathrm{N}$ & $\mathrm{Y}$ \\
\hline
\end{tabular}

Standard errors in parentheses; ${ }^{*} p<0.10,{ }^{* *} p<0.05,{ }^{* * *} p<0.01$

The total number of firm-year observations in the full sample are 38,016 .

Notes: This table summarizes the impact of provisioning requirements of restructured loans on zombie lending using a triple difference specification. The dependent variable is log of debt of a firm in period $\mathrm{T}+1$. Columns 1-2 look at the Zombie firms borrowing from stressed banks with higher provisioning rates. A firm is classified as Zombie if the the firm received subsidized credit in time period T i.e. the firm is able to borrow loans at an average interest rate that is lower than the Prime Lending Rate (PLR) of State Bank of India and has Debt to Assets ratio > .15. A bank is classified as Stressed Bank if the proportion of non-performing loans in the total gross advances (loans) for the bank is in the top two terciles in the

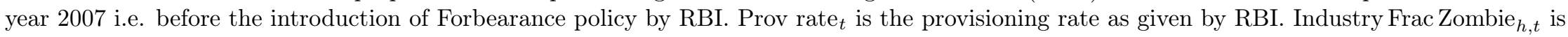
the fraction of total firms classified as a zombie in an industry in a period T. Bank Frac Zombie $b_{b, t}$ is the fraction of total firms classified as a zombie in an bank's portfolio in a period T. Only the triple interaction terms are shown though remaining interaction terms, not absorbed by the fixed effects, are also included but not shown for brevity. All specifications control for time invariant borrower characteristics and time varying firm size via Log of Sales. Borrower, year, industry-year, bank, and bank-year fixed effects are as indicated. Standard errors are clustered at the firm-level. 
Table IA.11: Placebo Test: Impact of Forbearance on Firms Linked to Foreign Banks

\begin{tabular}{|c|c|c|c|c|c|c|}
\hline Dep Var: Log Debt $_{j, t+1}$ & $(1)$ & $(2)$ & $(3)$ & $(4)$ & $(5)$ & $(6)$ \\
\hline Stressed Foreign Bank $_{b} *$ Zombie $_{j, t} *$ Forbearance $_{t}^{\text {Post } 2008}$ & $\begin{array}{r}-0.0401 \\
(0.548)\end{array}$ & $\begin{array}{r}-0.0912 \\
(0.609)\end{array}$ & & & & \\
\hline Stressed Foreign Bank $_{b} *$ Zombie $_{j, t} *$ Forbearance $_{t}^{\text {Post } 2013}$ & $\begin{array}{l}-1.042 \\
(0.665)\end{array}$ & $\begin{array}{l}-1.058 \\
(0.659)\end{array}$ & & & & \\
\hline Industry Frac Zombie $_{h, t} *$ Non Zombie $_{t} *$ Forbearance $_{t}^{\text {Post } 2008}$ & & & $\begin{array}{l}-0.0449 \\
(1.011)\end{array}$ & $\begin{array}{l}-0.310 \\
(2.409)\end{array}$ & & \\
\hline Industry Frac Zombie $_{h, t} *$ Non Zombie $_{t} *$ Forbearance $_{t}^{\text {Post } 2013}$ & & & $\begin{array}{l}2.041 \\
(2.079)\end{array}$ & $\begin{array}{c}3.174 \\
(4.401)\end{array}$ & & \\
\hline Bank Frac Zombie $_{h, t} *$ Non Zombie $_{t} *$ Forbearance $_{t}^{\text {Post } 2008}$ & & & & & $\begin{array}{c}0.448 \\
(1.850)\end{array}$ & $\begin{array}{c}2.617 \\
(3.400)\end{array}$ \\
\hline Bank Frac Zombie $_{h, t} *$ Non Zombie $_{t} *$ Forbearance $_{t}^{\text {Post } 2013}$ & & & & & $\begin{array}{l}0.0523 \\
(2.182)\end{array}$ & $\begin{array}{l}-0.706 \\
(2.987)\end{array}$ \\
\hline No. of Obs. & 1038 & 1038 & 1038 & 1038 & 1038 & 1038 \\
\hline R-sq. & 0.913 & 0.919 & 0.913 & 0.949 & 0.913 & 0.949 \\
\hline Borrower FE & Y & Y & $\mathrm{Y}$ & Y & $\mathrm{Y}$ & $\mathrm{Y}$ \\
\hline Year FE & $\mathrm{N}$ & Y & $\mathrm{N}$ & Y & $\mathrm{N}$ & $\mathrm{Y}$ \\
\hline Industry X Year FE & $\mathrm{N}$ & $\mathrm{N}$ & $\mathrm{N}$ & Y & $\mathrm{N}$ & $\mathrm{N}$ \\
\hline Bank FE & $\mathrm{N}$ & $\mathrm{Y}$ & $\mathrm{N}$ & Y & $\mathrm{N}$ & $\mathrm{Y}$ \\
\hline Bank X Year FE & $\mathrm{N}$ & $\mathrm{N}$ & $\mathrm{N}$ & $\mathrm{N}$ & $\mathrm{N}$ & $\mathrm{Y}$ \\
\hline
\end{tabular}

Standard errors in parentheses; ${ }^{*} p<0.10,{ }^{* *} p<0.05,{ }^{* * *} p<0.01$

The total number of firm-year observations in the full sample are 38,016 .

Notes: This table summarizes the placebo results for the impact of regulatory forbearance on zombie lending using a triple difference specification for the subset of firms that borrow from foreign sector banks. The dependent variable is log of debt of a firm in period T +1 . A firm is classified as Zombie if the the firm received subsidized credit in time period $\mathrm{T}$ i.e. the firm is able to borrow loans at an average interest rate that is lower than the Prime Lending Rate (PLR) of State Bank of India and has Debt to Assets ratio > .15. A bank is classified as Stressed Foreign Bank if the proportion of non-performing loans in the total gross advances (loans) for the foreign bank is in the top two terciles in the year 2007 i.e. before the introduction of Forbearance policy by RBI. The indicator variable Forbearance ${ }^{\text {Post } 2008}$ takes a value 1 in the years Post 2008 i.e. after the introduction of Forbearance. The indicator variable Forbearance ${ }^{\text {Post } 2013}$ takes a value 1 in the years Post 2013 i.e. after the announcement of withdrawal of Forbearance by RBI. Industry Frac Zombie $h, t$ is the fraction of total firms classified as a zombie in an industry in time period T. Bank Frac Zombie ${ }_{b, t}$ is the fraction of total firms classified as a zombie in a bank's portfolio in time period T. Only the triple interaction terms are shown though remaining interaction terms, not absorbed by the fixed effects, are also included but not shown for brevity. All specifications control for time invariant borrower characteristics and time varying firm size via Log of Sales. Borrower, year, industry-year, bank, and bank-year fixed effects are as indicated. Standard errors are clustered at the firm-level. 
Table IA.12: Identification Using Proximity to the Regulator: Firms Linked to Private Sector Banks

\begin{tabular}{|c|c|c|c|c|c|c|}
\hline Dependent Variable: Log Debt $_{j, t+1}$ & $(1)$ & $(2)$ & $(3)$ & $(4)$ & $(5)$ & (6) \\
\hline Regulator Proximity $_{b} *$ Low Solvency $_{j, t} *$ Forbearance $_{t}^{\text {Post } 2008}$ & $\begin{array}{l}0.0317 \\
(0.307)\end{array}$ & $\begin{array}{l}0.0675 \\
(0.301)\end{array}$ & & & & \\
\hline Regulator Proximity $_{b} *$ Low Solvency $_{j, t} *$ Forbearance $_{t}^{\text {Post } 2013}$ & $\begin{array}{l}-0.326 \\
(0.215)\end{array}$ & $\begin{array}{l}-0.343 \\
(0.214)\end{array}$ & & & & \\
\hline Regulator Proximity $_{b} *$ Low Liquidity $_{j, t} *$ Forbearance $_{t}$ Post 2008 & & & $\begin{array}{c}0.114 \\
(0.234)\end{array}$ & $\begin{array}{c}0.128 \\
(0.230)\end{array}$ & & \\
\hline Regulator Proximity $_{b} *$ Low Liquidity $_{j, t} *$ Forbearance $_{t}$ Post 2013 & & & $\begin{array}{r}-0.0837 \\
(0.217)\end{array}$ & $\begin{array}{r}-0.0642 \\
(0.219)\end{array}$ & & \\
\hline Regulator Proximity $_{b} *$ Zombie $_{j, t} *$ Forbearance $_{t}{ }^{\text {Post } 2008}$ & & & & & $\begin{array}{l}-0.298 \\
(0.267)\end{array}$ & $\begin{array}{l}-0.280 \\
(0.268)\end{array}$ \\
\hline Regulator Proximity $_{b} *$ Zombie $_{j, t} *$ Forbearance $_{t}^{\text {Post } 2013}$ & & & & & $\begin{array}{l}0.0101 \\
(0.209)\end{array}$ & $\begin{array}{c}-0.0384 \\
(0.210)\end{array}$ \\
\hline No. of Obs. & 4808 & 4808 & 5376 & 5376 & 5393 & 5393 \\
\hline R-sq & 0.935 & 0.938 & 0.932 & 0.933 & 0.934 & 0.936 \\
\hline Borrower FE & $\mathrm{Y}$ & $\mathrm{Y}$ & $\mathrm{Y}$ & $\mathrm{Y}$ & $\mathrm{Y}$ & $\mathrm{Y}$ \\
\hline Year FE & $\mathrm{N}$ & Y & $\mathrm{N}$ & $\mathrm{Y}$ & $\mathrm{N}$ & $\mathrm{Y}$ \\
\hline Bank FE & $\mathrm{N}$ & $\mathrm{Y}$ & $\mathrm{N}$ & $\mathrm{Y}$ & $\mathrm{N}$ & $\mathrm{Y}$ \\
\hline
\end{tabular}

Standard errors in parentheses; ${ }^{*} p<0.10,{ }^{* *} p<0.05,{ }^{* * *} p<0.01$

The total number of firm-year observations in the full sample are 38,016 .

Notes: This table summarizes the impact of regulatory forbearance on lending to low-solvency (columns 1-2), low-liquidity firms (columns 3-4), and zombie (columns 5-6) firms with proximity to the regulator for the subset of firms that borrow from private sector banks using a triple difference specification. The dependent variable is the log of debt of a firm in period $\mathrm{T}+1$. A firm is classified as Zombie if the the firm received subsidized credit in time period $\mathrm{T}$ i.e. the firm is able to borrow loans at an average interest rate that is lower than the Prime Lending Rate (PLR) of State Bank of India and has Debt to Assets ratio > .15. A firm is classified as

Low Solvency if the Debt to equity measure of the firm in time period T is above median. A firm is classified as Low Liquidity if the cash ratio measure of the firm in time period $\mathrm{T}$ is below median. Regulator Proximity ${ }_{b}$ is 1 if the distance of the bank headquarters is below the median value and 0 otherwise. Only the triple interaction terms are shown though remaining interaction terms, not absorbed by the fixed effects, are also included but not shown for brevity. All specifications control for time-invariant borrower characteristics and time-varying firm size via log of sales. Borrower, year, and bank fixed effects are as indicated. Standard errors are clustered at firm level. 